\title{
Argonne's Performance Assessment of Major Facility Systems to Support Semiconductor Manufacturing by the National Security Agency/R Group, Ft. Meade, Maryland:
}

\section{Document Index}

by W. Harrison and G.M. Miller

Special Projects Group, Energy Systems Division,

Argonne National Laboratory, 9700 South Cass Avenue, Argonne, Illinois 60439

December 1990

Work sponsored by National Security Agency, Fort George G. Meade, Maryland 


\section{CONTENTS}

INTRODUCTION

EXPLANATION OF FILE INDEXES

1 QUALITY-ASSURED RECORDS OF FORMAL AND INFORMAL

REVIEWS

1.1 Index of Documents Pertaining to U.S. Army Corps of

Engineers / Baltimore District (USACE/BD)-Sponsored Formal

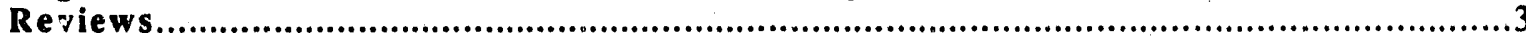

1.1.1 COECI

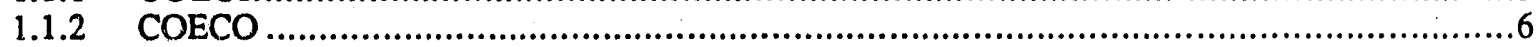

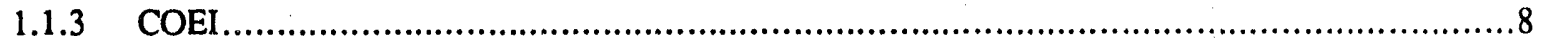

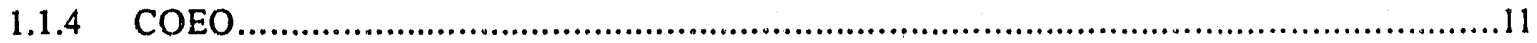

1.2 USACE/BD-Sponsored Formal Reviews........................................................................15

1.2.1 Performance Review of the Clean Room Systems at the Special

Process Laboratories Building, Ft. Meade, Maryland .....................................................17

1.2.2 System Performance Review of the Deionized-Water and Wastewater

Treatment Systems at the Special Process Laboratories, Ft. Meade,

Maryland

1.2.3 Special On-Site Review of the High-Purity-Gas Piping System, SPL

Building, Ft. Meade, Maryland

1.3 Index of Documents Pertaining to National Security Agency

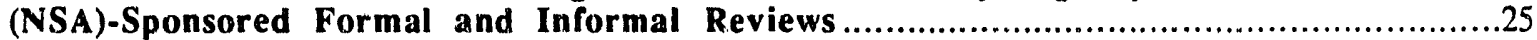

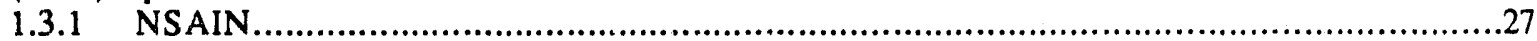

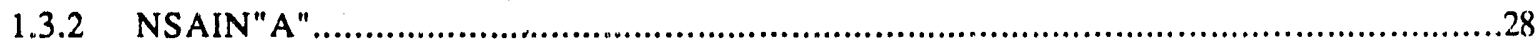

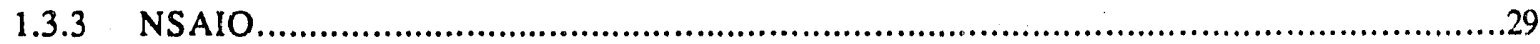

1.3 .4 NSAIO" A

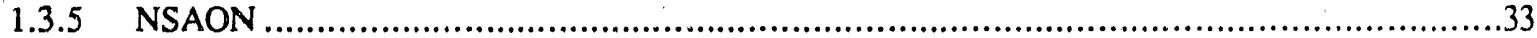

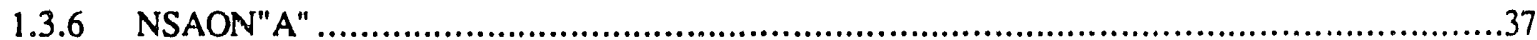

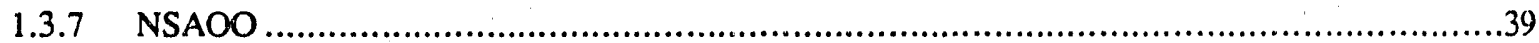

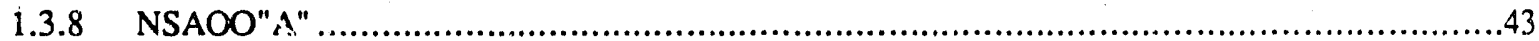

1.4 Index of Documents Pertaining to NSA-Sponsored Formal

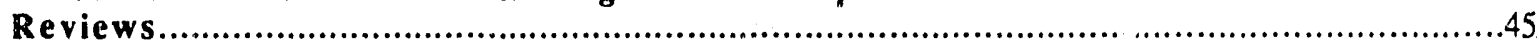

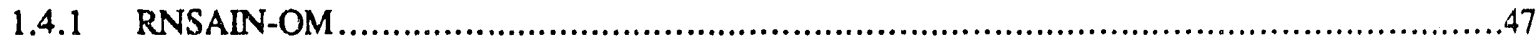

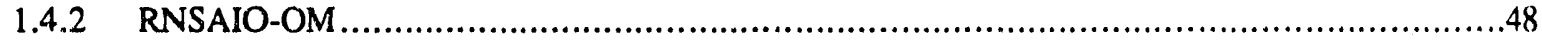

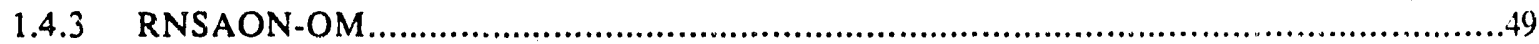

1.4 .4 RNSAOO-OM

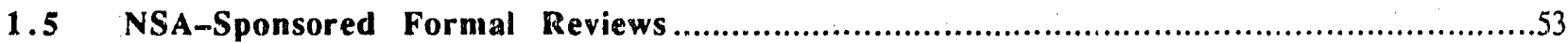

1.5.1 Performance Review of National Semiconductor's (NSC's) Proposed

Enhancements to the Clean Room Systems located in NSA's SPL

Building at Ft. Meade, Maryland .....................................................

1.5.2 Formal Performance Review of the Deionized-Water and Wastewater-
Treatment Systems located in NSA's SPL Building at Ft. Meade,

Maryland....

1.5.3 Formal Performance Review of the High-Purity-Gas Piping System

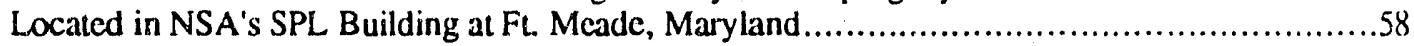

1.5.4 Formal Performance Review of NSA's Operations and Maintenance

Concept for the SPL Building.

1.6 NSA-Sponsored Informal Reviews

1.6.1 Informal Review of the Proposed Enhancements to the Clean Room

Systems, SPL Building, Ft. Meade, Maryland

1.6.2 Informal Review of Package 5, Environmental Protection Systems

Enhancements, SPL Building, Ft. Meade, Maryland 


\section{CONTENTS (Cont'd)}

1.6.3 Informal Review of the Lime-Addition System for the Wastewater-

Treatment System, SPL Building, Ft. Meade, Maryland

1.6.4 Informal Review of the LEPCO/MEBES III Document Review, SPL

Building, Ft. Meade, Maryland.

1.6.5 Informal Review of the ION Exchange Associates, Inc., Specifications

for Multi-Media Filters, SPL Building, Ft. Meade, Maryland.

1.6.6 Informal Review of the Proposed Enhancements to the Deionized Water System located in the NSA SPL Building, Ft. Meade, Maryland .......................................71

1.6.7 Informal Review of the Sprinkler Sysem, SPL Building, Ft. Meade,

Maryland

1.6.8 Informal Review of the Chilled Water System, SPL Building, Ft. Meade, Maryland..

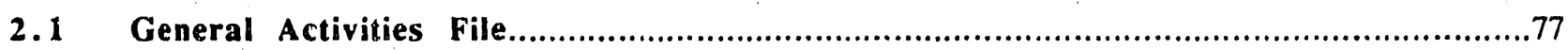

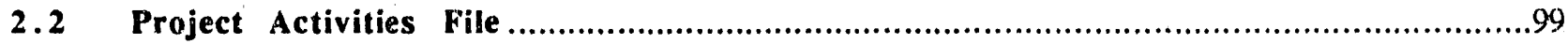

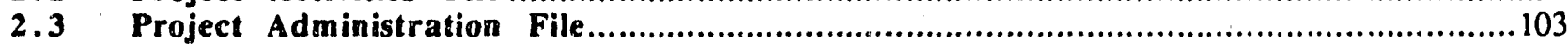

2.4 Review of Request for Information (RFI) Documents............................................... 107

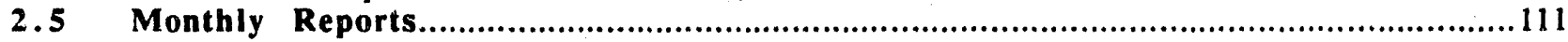

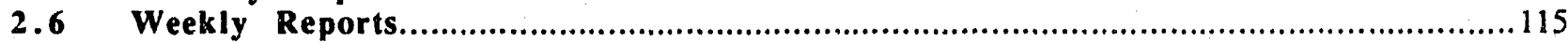

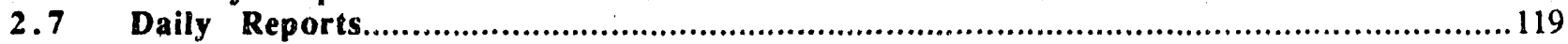

2.8 Support File for Formal Review of NSA's Operations and Maintenance Concept for the SPL Building........................................................ 123

2.9 Basic SPL Specifications and Preliminary Design Calculations......................................127

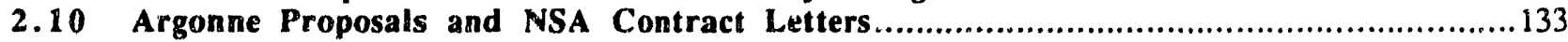

\section{FIGURES}

Flowchart of the ANL "Formal-Review" Process. vii

Location and Custody of the Three Copies of the Records Collected during Argonne

National Laboratory's Performance Assessment of Major Facility Systems in NSA's SPL

Building $x$ vii

\section{TABLES}

1 File Siructure for Documents Generated during USACE/BD-Sponsored Formal

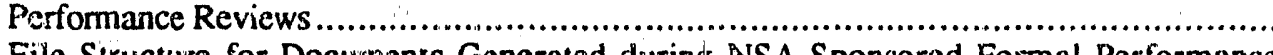

2. File Structure for Documents Generated during NSA-Sponsored Formal Performance

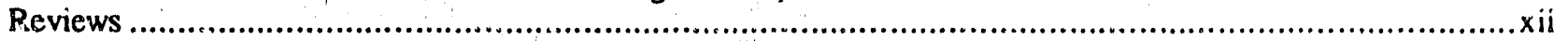

3 File Structure for the Records for NSA-Sponsored Informal Reviews........................................................ xiv

$4 \quad$ Project-Related Documents Generated during NSA Sponsorship ......................................................

5 Outline of File Structure for Formal Reviews, Informal Reviews, and Project-Related

Documents Generated during USACE/BD and NSA Sponsorship... 


\section{INTRODUCTION}

\section{BACKGROUND AND PURPOSE}

The National Security Agency (NSA) was authorized in 1983 to construct a semiconductor and circuit-board manufacturing plant at its Ft. Meade, Maryland, facility. This facility was to become known as the Special Process Laboratories (SPL) building. Phase I construction was managed by the U.S. Army Corps of Engineers, Baltimore District (USACE/BD) and commenced in January 1986. The Phase I design contractor was HDR, Inc., and the construction contractor was Pike-Paschen. Phase I construction provided the basic building and support systems, such as the heating, ventilating, and airconditioning system, the deionized-water and wastewater-treatment systems, and the high-purity-gas piping system. Phase II construction involved fitting the semiconductor manufacturing side of the building with manufacturing tools and enhancing various aspects of the Phase I construction. Phase II construction was managed by NSA and commenced in April 1989. The Phase II contractor was National Semiconductor Corporation (NSC). The semiconductor manufacturing side of the SPL building was officially signed over to the government (NSA) on October 1, 1990.

Argonne National Laboratory (ANL) was contracted by USACE/BD midway through the Phase I construction period to provide quality-assured performance reviews of major facility systems in the SPL. Following completion of the Phase I construction, ANL continued its performance reviews under NSA sponsorship, focusing its attention on the enhancements to the various manufacturing support systems of interest.

To accomplish its performance reviews, ANL provided three on-site engineers to gather information on design and construction deficiencies, to witness system acceptance tests, and to act as government technical representatives in meetings between the government and its contractors. When a specific, "formal" performance review was requested by the government, ANL would assemble experts from academia, industry, and consulting firms into peer review panels. Each panel would visit the SPL, consult with ANL's on-site engineers, inspect the system under investigation, and complete a review report based on its findings. Panels were chaired by engineers or scientists from ANL, who conducted the reviews for USACE/BD or NSA.

The purpose of this document is to provide a guide to the files that were generated by ANL during its term of technical assistance to USACE/BD and NSA and to explain the quality assurance program that was implemented when ANL conducted its performance reviews of the SPL building's systems. One set of the ANL project files is located at NSA, Ft. Meade, and two sets are at Argonne, Illinois. The ANL sets will be maintained until the year 2000 , or for the 10 -year estimated life of the project. 


\section{QUALITY ASSURANCE PROGRAM}

\section{Historical Perspective}

Argonne conducted its formal performance reviews according to a quality assurance (QA) program developed earlier for the U.S. Department of Energy (DOE). The DOE had required peer reviews of government-sponsored contractor reports submitted to satisfy major programmatic milestones of DOE's salt host-rock portion of the Civilian Radioactive Waste Management Program. The salt-rock portion of this DOE program is now defunct, but the QA review procedures developed by ANL under DOE sponsorship were ideally suited to the peer reviews of the SPL systems required by USACE/BD and NSA. (Several "informal" performance reviews of SPL systems were also conducted for ANL's government sponsors. These reviews were designated as informal because review documentation did not conform with the requirements for formal reviews, as indicated in Fig. 1.) The methods, controls, and procedures used by Argonne in conducting its formal performance reviews (documented in Argonne National Laboratory Report ANL/EES-TM-312, released in 1986 ${ }^{1}$ ) were instituted to ensure that the results of ANL's peer review activities were of the highest quality, were meticulously documented, and were responsive to the needs and directives of DOE and other government sponsors.

\section{QA Review Program Characteristics}

The essential characteristics of a formal, ANL-conducted peer review are as follows (see Fig. 1 for the NSA example):

1. Independent. The government-agency sponsor provides nothing more than general guidance to ANL when requesting a review. The individual views of expert, auxiliary peer review panelists are obtained and integrated into a written narrative by ANL core panelists acting as editors for comments pertinent to their discipline areas. Each auxiliary panelist must concur with the way in which the ANL editors have represented his/her comments in the draft ANL report and with the associated written presentation relevant to his/her area of expertise. If an auxiliary panelist cannot agree with a relevant aspect of a draft ANL report, the panelist's reasons for lack of agreement are incorporated into the text of the report.

2. Comprehensive. ANL-conducted reviews are multidisciplinary and cover relevant technical, regulatory, and institutional issues. The list of available auxiliary panelists covers a wide range of disciplines and can be readily expanded as the need is identified for coverage of additional areas of expertise. 


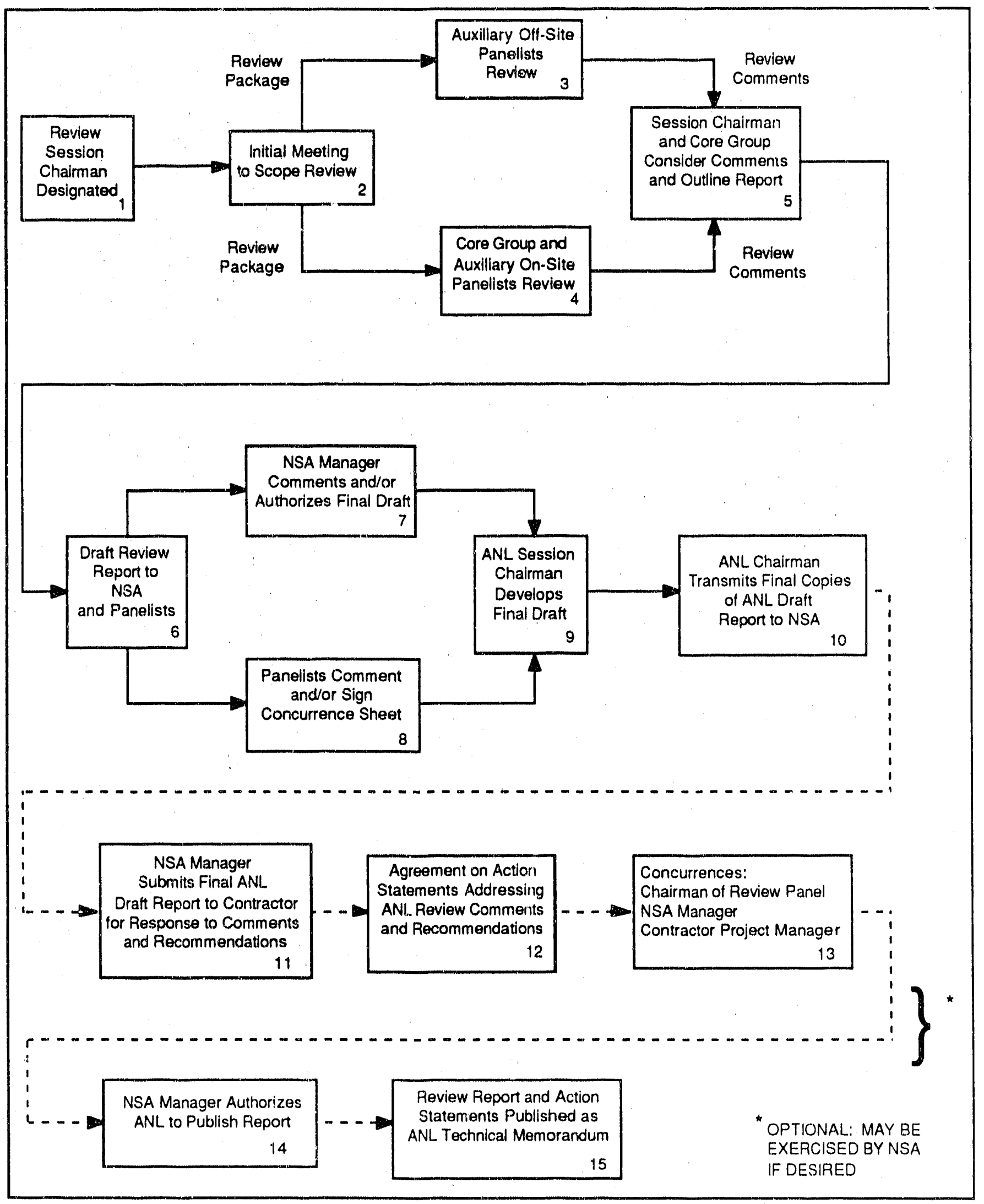

Figure 1. Flowchart of the ANL "Formal-Review" Process (Documentation of a formal review requires generation of an appropriate letter, memo-to-file, or report at each step shown.) 
3. Responsive. The reviews consider the government sponsor's need to satisfy federal and state regulatory agency requirements, and they are completed in a timely manner. As part of its regular activities, the ANL core group maintains familiarity with the progress and needs of a sponsor's program.

4. Subject to Quality Assurance (QA). The reviews are conducted according to a DOEapproved QA plan that follows the relevant stipulations of NQA-12-4. The review program has been and will continue to be evaluated and audited by QA specialists from ANL and DOE.

5. Dorumented. Completed reviews are either published as ANL technical memorandums or transmitted in limited numbers to the government-agency sponsor, with backup copies being retained in the project's QA files. In either case, the ANL report transmitted to the sponsor contains a complete record of each review, including a copy of the sponsor's letter requesting the review, the carefully compiled and organized presentation of the panelists' comments, summaries of the credentials of the reviewer's, and the action statements resulting from the comment-resolution process (if requested by the sponsor).

To summarize, ANL-conducted peer reviews provide essential guidance to a sponsor on the adequacy and credibility* of the important contractor documents and plans that underpin a sponsor's program. Peer review panelists are unbiased, acknowledged experts in their fields and are independent of government or contractor influence. The ANL core group has the necessary resources and leadership to consistently apply a review method of the highest quality. Application of that method results in comprehensive peer reviews of the technical, regulatory, and institutional aspects of each contractor document that is reviewed. The peer review results, when published and/or distributed, are capable of withstanding intense public and judicial scrutiny.

\section{Relationship to Other QA Programs, Procedures, and Requirements}

The original ANL QA program was prepared using several documents as guidance. As stated in DOE Order CH5700.6A of August 13, 1981, DOE policy is that national consensus QA standards are to be applied to its programs if suitable ones are available. In this regard, Title 10, Part 50, of the Code of Federal Regulations (10 CFR 50) $)^{5}$ states that ANSI/ASME NQA-12-4 is the presrred standard for meeting QA requirements for nuclear facilities. ANL, which is administratively responsible to DOE, has developed and implemented a QA program ${ }^{6}$ in accordance with Order CH5700.6A. As a consequence, the requirements of ANSI/ASME NQA-1 are addressed by the stated QA policies of ANL. Sections 1-19

\footnotetext{
* Adequacy of documents refers to their ability to meet the relevant regulatory requirements. Credibility of documents refers to the validity of the assumptions, methods, and conclusions, as well as to the completeness of subject matter colerage.
} 
of ANL/EES-TM-312 constitute the QA plan: Secs. 1-18 correspond to the 18 basic QA requirements presented in ANSI/ASME NQA-1, and Sec. 19 presents informacion on the requirements for deliverables and reporting for the project. Because of the type of work performed for the peer review task, some of the basic requirements of NQA-1 are not applicable. Otherwise, appropriate QA requirements in NQA-1 and in the QA specification supplied by DOE's Salt Rupository Project Office (SRPO) are presented, along with responsibilities and activities for meeting those requirements.

The document for ANL's QA program (the "QA plan") also includes seven appendixes. The correspondence between specific elements of the QA specification provided by SRPO and the sections of the QA plan is detailed in App. A. Appendixes B-F present the detailed QA procedures developed for implementing the project $\mathrm{QA}$ requirements set forth in the QA plan, and App. G contains information on the requirements for deliverables and reporting for the project. The foregoing procedures and requirements were applied in ANL's conduct of formal performance reviews for USACE/BD and NSA.

\section{Implementation of QA Program for SPL-System Performance Reviews}

The goals of the QA program described above, as applied to formal performance reviews of the SPL building's major facility systems, were not always fully achieved. Time constraints were in some cases too severe to permit adherence to every detail specified in the QA procedures for a formal review. To cite one example, a letter from the sponsor requesting a review was sometimes not forthcoming. Rather, verbal instructions were issued on tne day that the review team assembled at Ft. Meade. Thus, documents expected from the QA specifications (see, for example, Fig. 1) that are not present in the files are not "missing documents;" they were, in fact, never generated.

\section{REFERENCES}

${ }^{1}$ Edgar, D. E., Quality Assurance Program: Argonne Peer Review Activities for the Salt Host-Rock Portion of the Civilian Radioactive Waste Management Program, Argonne National Laboratory Report ANL/EES-TM-312 (Aug. 1986).

${ }^{2}$ Quality Assurance Program Requirements for Nuclear Facilities, ANSI/ASME NQA-1-1983 Edition, American Society of Mechanical Engineers, New York (July 1, 1983).

${ }^{3}$ Addenda to ANSI/ASME NQA-1-1983 Edition, ANSI/ASME NQA-1-1a-1983, American Society of Mechanical Engineers, New York (Dec. 31, 1983).

${ }^{4}$ Addenda to ANSI/ASME NQA-1-1983 Edition. ANSI/ASME NQA-1-1b-1984, American Society of Mechanical Engineers, New York (March 15, 1985).

${ }^{5}$ Quality Assurance Criteria for Nuclear Power Plants and Fuel Reprocessing Plants, Code of Federal Regulations, Titlc 10, Part 50 (10 CFR 50), App. B (Jan 1, 1985).

${ }^{6}$ ANL Quality Assurance Policy and Procedures Manual, Argonne National Laboratory (most recently revised on Oct. 2, 1989). 


\section{EXPLANATION OF FILE INDEXES}

The indexes of files that make up the body of this report inventory all of the records collected during Argonne National Laboratory's performance assessment of major facility systems in NSA's SPL building. One part of the project files consists of quality-assured records for (1) the formal, qualityassured performance reviews conducted for both USACE/BD and NSA and (2) the informal reviews conducted for NSA alone. The other part covers non-quality-assured records for project-related documents (see below).

Here, "quality-assured" refers to the strict procedures used in the handling of documents pertaining to reviews conducted for USACE/BD and NSA. The receipt and/or transmittal of each document was recorded in the indexes that follow. Placement of documents in these files was determined by the source of each document (whether it originated from Argonne, USACE/BD, NSA, or other party). Each document was coded with a prefix (dependent on the type of document) and numbered consecutively by the date it was received. To preserve security, two sets of these files were maintained, labeled QA-1 and QA-2. Documents in these files were stored in locked, fireproof file cabinets. The file cabinets were in two rooms and separated by a masonry wall. "Quality-assured" documents differ from project-related documents in that strict monitoring of correspondence was not required in the case of documents not directly pertaining to a formal or informal review. As a result, it cannot be stated that every document generated or received by ANL has been included in these "non-quality-assured" files.

\section{Formal Review Files}

During Phase I of the project, which involved construction of the building shell and the major facility support systems, sponsorship for ANL performance assessments was provided by USACE/BD. During this period, two types of files were kept: a correspondence file and a file for documents pertaining to formal performance reviews. Table 1 illustrates the file structure for the documents generated during USACE/BD-sponsored formal performance reviews. After the completion of Phase I construction, the National Security Agency (NSA) sponsored ANL performance reviews during Phase II construction, the period during which enhancements to the major facility support systems and building fit-up (installation of wafer-fabricating equipment) were accomplished. Files for documents pertaining to quality-assured formal reviews conducted under USACE/BD sponsorship were closed. New files using the same basic structure were created for Phase II formal reviews. Table 2 illustrates the file structure follow w the advent of NSA sponsorship.

\section{Informal Review Files}

As a result of NSA sponsorship, the scope of ANL's performance assessments was broadened to include "informal" reviews of major facility systems. To track non-quality-assured informal reviews, "informal review files" were created for correspondence and performance review reports related to these activities. Documents added to these files were numbered and logged under the same strict controls as documents pertaining to formal reviews. As with the files for the quality-assured reviews, two copies of 
Table 1. File Structure for Documents Generated during USACE/BD-Sponsored Formal Performance Reviews

\subsection{CORRESPONDENCE}

File Prefix

COECI*

COECO

COEI

COEO

\section{Explanation}

Documents originating with USACE and incoming (I) to ANL (Ref. No. 1.1.1)

Documents originating with ANL and outgoing (O) to USACE (Ref. No. 1.1.2)

Incoming (I) documents received by ANL and originating from parties other than USACE (Ref. No 1.1.3)

Outgoing $(\mathrm{O})$ documents originating from ANL and transmitted to parties other than USACE (Ref. No. 1.1.4)

\subsection{FORMAL REVIEWS}

\section{Reference}

Number

1.2 .1

1.2 .2

1.2 .3

\section{Explanation}

All documents pertaining to the Performanc: Review of the Clean Room Systems at the Special Process Laboratories Building, F.. Meale, Maryland

All documents pertaining to the System Performance Review of the Deionized Water and Wastewater-Treatment Systems at the Special Process Laboratories, Ft. Meade, Maryland

All documents pertaining to the Special On-Site Review of the High-Purity-Gas Piping System, SPL Building, Ft. Meade, Maryland

* "COE" stands for Corps of Engineers and is shorthand for U. S. Army Corps of Engineers / Baltimore District. 
Table 2. File Structure ior Documents Generated during NSA-Sponsored Formal Performance Reviews

\section{$1.3 \& 1.4$ CORRESPONDENCE}

File Prefix

NSAIN and

NSAIN"A"

NSAIO and

NSAIO"A"

NSAON and

NSAON"A"

NSAOO and

NSAOO"A"

RNSAIN-OM

RNSAIO-OM

RNSAON-OM

RNSAOO-OM

\section{Explanation}

Documents originating with NSA and incoming (I) to ANL (Ref. Nos. 1.3.1 and 1.3.2)

Incoming (I) documents received by ANL and originating from parties other than NSA (Ref. Nos. 1.3.3 and 1.3.4)

Documents originating with ANL and outgoing (O) to NSA (Ref. Nos, 1.3.5 and 1.3.6)

Outgoing $(0)$ documents originating with ANL and transmitted to parties other than NSA (Ref. Nos. 1.3.7 and 1.3.8)

Documents pertaining to the Formal Performance Review of NSA's Opcrations and Maintenance Concept for the SPL Building, originating with NS $\Lambda$ and incoming (I) to ANL (Ref. No. 1.4.1)

Incoming (I) documents pertaining to the Formal Performance Review of NSA's Operations and Maintenance Concept for the SPL Building received by ANL and originating from parties other than NSA (Ref. No. 1.4.2)

Documents periaining to the Formal Performance Review of NSA's Opcrations and Maintenance Concept for the SPL Building, originating with ANL and outgoing (O) to NSA' (Ref. No. 1.4.3)

Outgoing (O) documents pertaining to the Formal Performance Review of NSA's Operations and Maintenance Concept for the SPL Building, originating with ANL and transmitted to parties other than NSA (Ref. No. 1.4.4)

\subsection{FORMAL REVIEWS}

\section{Reference}

Number

\section{5 .1}

1.5 .2

1.5 .3

i. 5.4

\section{Explanation}

All documents pertaining to the Formal Performance Review of National Semiconductor's (NSC's) Proposed Enhancements to the Clean Room Systems Located in NSA's SPL Building at Ft. Meade, Maryland

All documents pertaining to the Formal Performance Review of the Deionized-Water and Wastewater-Treatment Systems Located in NSA's SPL Building at Ft. Mcade, Maryland

All documents pertaining to the Formal Performance Review of the High-Purity-Gas Piping System Located in NSA's SPL Building at Ft. Meade, Maryland

All documents pertaining to the Formal Performance Review of NSA's Operations and Maintenance Concept for the SPL Building 
the informal review files were maintained. Thus, the records for NSA-sponsored informal reviews can appropriately be termed "quality-assured." Table 3 illustrates the file structure for the QA records for the informal reviews.

\section{Project-Related Files}

In order to more completely document project-related activities, the "General Activities" file was created to encompass all general correspondence and transmittals not directly pertaining to a formal or informal review. Files were also formed to record administrative activities conducted by the ANL principal investigator for the project (Wyman Harrison) and ANL's QA custodian (Gina Miller). Entries in these files are listed in Sec. 2, entitled "Non-Quality-Assured Records of Project-Related Documents." Table 4 outlines the file structure for project-related documents generated during NSA sponsorship. Table 5 illustrates the entire file structure for quality-assured formal and informal reviews and non-qualityassured project-related documents.

\section{Document Numbering and Storage}

Each of the documents listed in the pages that follow has been numbered. Each group of documents under a given file number has been separated from otner groups by labeled file dividers. One set of docurnents is stored at AN IL in a fireproof locking file cabinet under the custody of John Kelley, ANL Quality Assurance Representative. A second set is maintained by the ANL Project Manager, Wyman Harrison. A third set is in the possession of NSA, having been transferred to David Kokalis (NSA / R-Group) in December 1990. The ANL document sets will be maintained until the year 20()), or for the estimated 10-year life of the SPL. Figure 2. illustrates the location and custody of the three copies of the records collected during Argonne National Laboratory's performance assessment of major facility systems in NSA's SPL building. 
Table 3. File Structure for the Records for NSA-Sponsored Informal Reviews

\subsection{INFORMAL REVIEWS}

File Prefix

NSAIN and

NSAIN"A"

NSAIO and

NSAIO"A"

NSAON and

NSAON"A"

"SAOO and AOO"A"

\section{Explanation}

Documents originating with NSA and incoming (I) to ANL (Ref. Nos. 1.3.1 and 1.3.2)

Incoming (I) documents received by ANL and originating from parties other than NSA (Ref. Nos. 1.3.3 and 1.3.4)

Documents originating with ANL and outgoing (O) to NSA (Ref. Nos. 1.3.5 and 1.3.6)

Outgoing $(O)$ documents oripinating with ANL and transmitted to parties other than NSA (Ref. Nos. 1.3.7 and 1.3.8)

\section{Reference}

Number

1.6 .1

1.6 .2

1.6 .3

1.6 .4

1.6 .5

1.6 .6

1.6 .7

1.6 .8

\section{Explanation}

All documents pertaining to the Informal Review of the Proposed Enhancements to the Clean Room Systems, SPL Building, Ft. Meade, Maryland

All documents pertaining to the Informal Review of the Package 5, Environmental Protection Systems Enhancements, SPL Building, Ft. Meade, Maryland

All documents pertaining to the Informal Review of the Lime-Addition System for the Wastewater-Treatment System, SPL Building, Ft. Meade, Maryland

All documents pertaining to the Informal Review of the Lepco/Mebes III Document Review, SPL Building, Ft. Me is , Maryland

All documents pertaining to the Informal Review of the Ion Exchange Associates, Inc., Specifications for Multi-Media Filters, SPL Building, Ft. Meade, Maryland

All documents pertaining to the Informal Review of the Proposed Enhancements to the Deionized Water System Located in the NSA SPL Building, Ft. Meade, Maryland

All documents pertaining to the Informal Review of the Sprinkler System, SPL Building, Ft. Meade, Maryland

All documents pertaining to the Informal Review of the Chilled Water System, SPL Building, Ft. Meade, Maryland 
Table 4. Project-Related Documents Generated during NSA Sponsorship

\section{FILES FOR PROJECT-RELATED DOCUMENTS}

File Prefix

GA

SPLPA

PAF

RFI

MR

WR

DR

OMS

SD

$\mathrm{CD}$

\section{Explanation}

General Activities File: All project-related documents not directly pertaining to a formal or informal review and not appropriate for placernent in the following files (Ref. No. 2.1)

Project Acti vities File (Meetings with R-Group Staff): All documents pertaining to administrative directives to ANL by the NSA/R-Group, not directly pertaining to formal or informal reviews and not appropriate for placement in the general activities file (Ref. No. 2.2)

Project Administration File: All documents pertaining to the custodial maintenance of the quality-assured project files (Ref. No. 2.3)

Review of Request for Information (RFI) Documents: Reports to sponsor regarding requests for information (Ref. No. 2.4)

Monthly Reports to Sponsor (Ref. No. 2.5)

Weekly Reports to Sponsor (Ref. No. 2.6)

Daily Reports to Sponsor (Ref. No. 2.7)

Support File for the Formal Performance Review of NSA's Operations and Maintenance Concept for the SPL Building (Ref. No. 2.8)

Basic SPL Specifications and Preliminary Design-Calculations (Ref. No. 2.9)

Argonne Proposals amd NSA Contract Letters (Ref. No. 2.10) 
Table 5. Outline of File Structure for Formal Reviews, Informal Reviews, and Project-Related Documents Generated during USACE/BD and NSA Sponsorship

\section{QUALITY-ASSURED RECORDS OF FORMAL AND INFORMAL PERFORMANCE REVIEWS SPONSORED BY USACE/BD AND NSA}

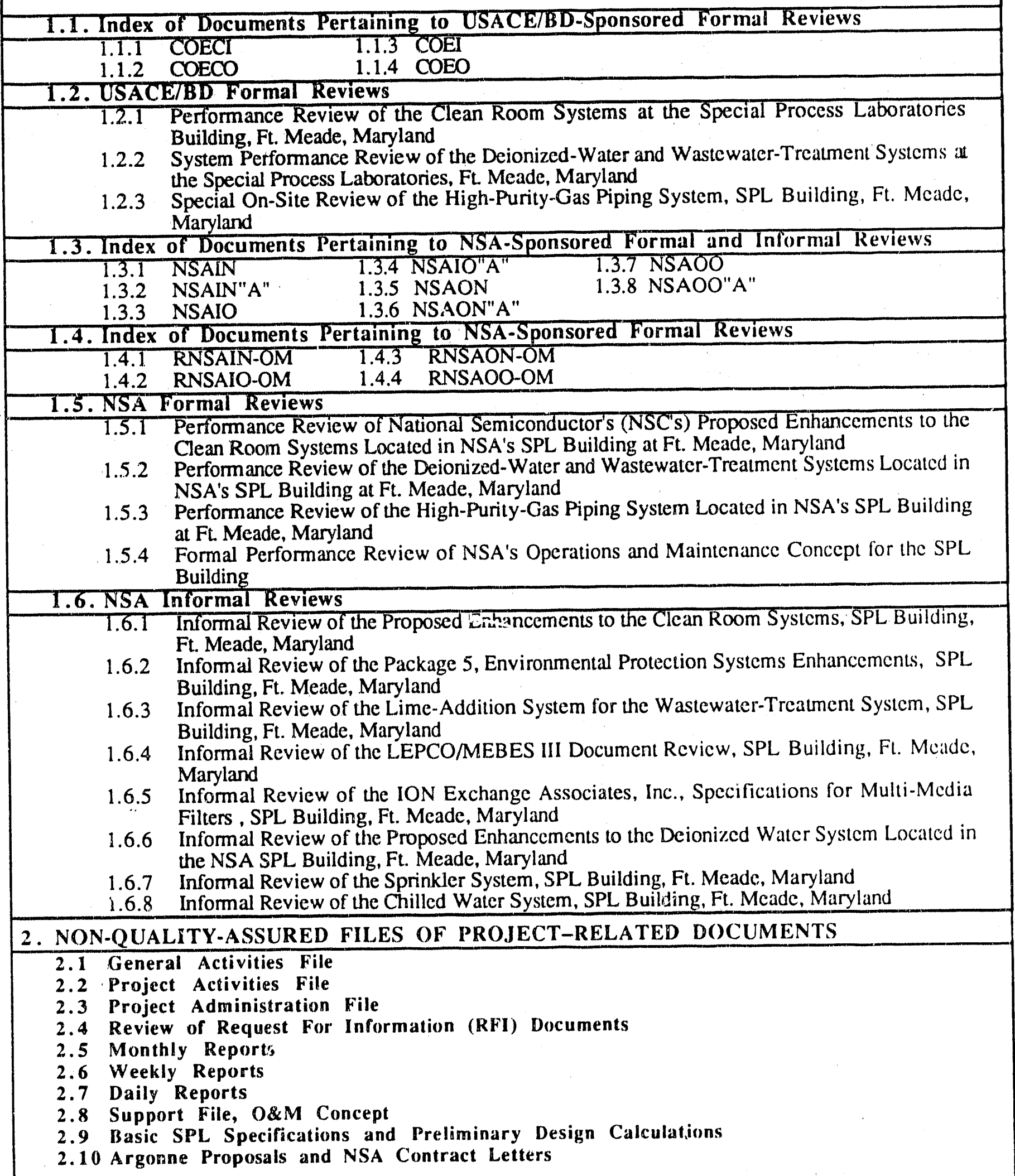




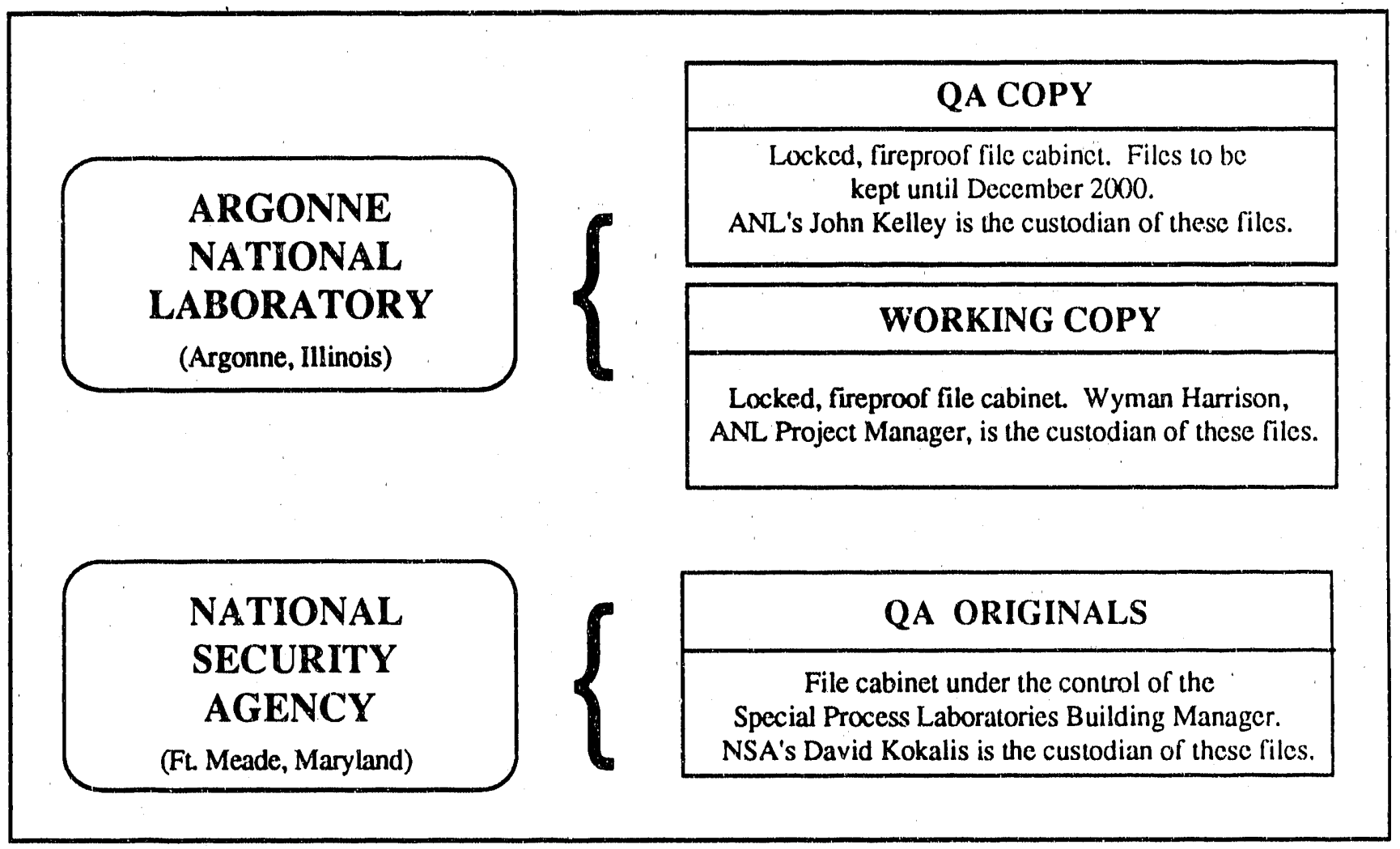

Figure 2. Location and Custody of the Three Copies of the Records Collected during Argonne National Laboratory's Performance Assessment of Major Facility Systems in NSA's SPL Building 


\section{$1 / 2$}

1 QUALITY-ASSURED RECORDS OF FORMAL AND INFORMAL REVIEWS 
1.1 Index of Documents Pertaining to U.S. Army Corps of Engineers / Baltimore District (USACE/BD)Sponsored Formal Reviews 
INDEX FOR CORRESPONDENCE FILE 1.1.1 (COECI) Documents Incoming from USACE/BD

\begin{tabular}{|c|c|c|c|c|}
\hline COECI- & Dated/Rcvd & To/From & Description & Subject \\
\hline 001 & $\begin{array}{l}112988 / \\
120888\end{array}$ & Harrison/Merski & Lotter & $\begin{array}{l}\text { Special Gas \& Liquid Distribution Systems Revicw } \\
\text { Panelists, SPL, NSA, Ft. Mcade, Maryland } \\
\text { (Concurrence with ANL Selection of Punclists) }\end{array}$ \\
\hline 002 & 120888 & Harrison/Merski & Letter & $\begin{array}{l}\text { Deiunized Water and Industrial Waste Treatment } \\
\text { Systems Review Panelists (TP's 11240, 11390) } \\
\text { SPL, NSA, Ft. Meade, Maryland (Concurrence } \\
\text { with ANL's Selection of Panclists) }\end{array}$ \\
\hline 003 & 121288 & Harrison/Merski & Letter. & $\begin{array}{l}\text { Integrated Clean Room Systems Revicw Panelists, } \\
\text { (TP 13040), Special Process Laboratorics, National } \\
\text { Security Agency, Fl. Meade, Maryland } \\
\text { (Concurrence with ANL Sclection of Panclists) }\end{array}$ \\
\hline
\end{tabular}


INDEX FOR CORRESPONDENCE FILE 1.1.2 (COECO)

Dosuments Outgoing to USACE/BD

\begin{tabular}{|c|c|c|c|c|}
\hline COECO & Dated/Rcvd & To/From & Description & Subject \\
\hline 001 & 100488 & Magnifico/Harrison & Enclosures & $\begin{array}{l}\text { NSA Area Office Concurrence with ANL's } \\
\text { Selection of Panelists for Review of Performance of } \\
\text { High-Purity-Gas Piping Systems } \\
\text { Resumes of Antoinctte Engclkemeir, Al Jckel, } \\
\text { Herb Stevens, and Stanley Stoy. }\end{array}$ \\
\hline 002 & 101488 & Magnifico/Harrison & $\begin{array}{l}\text { Letter } \\
\text { Enclosures }\end{array}$ & $\begin{array}{l}\text { NSA Area Office Concurrence with ANL's } \\
\text { Selection of Panelists for 'Review of Performance of } \\
\text { Deionization and Wastewater-Trcalment Systems } \\
\text { Resumes of Ralph Frost, Robert Peters, William } \\
\text { Midkiff, and S. D. Hooks }\end{array}$ \\
\hline 003 & 101988 & Magnifico/Harrison & Enclosure & $\begin{array}{l}\text { NSA Area Office Concurrence with ANL's } \\
\text { Selection of Mr. William V. Collentro as a } \\
\text { Panelist for Review of Performance of Deionization } \\
\text { and Wastewater-Treatment Systems } \\
\text { Resume of William Collentro }\end{array}$ \\
\hline 004 & 110388 & Magnifico/Harrison & $\begin{array}{l}\text { Letter } \\
\text { Enclosures }\end{array}$ & $\begin{array}{l}\text { NSA Area Orfice Concurrence with ANL's } \\
\text { Selection of Panclists for Review of Performance of } \\
\text { Clean Room Systems in the Special Process } \\
\text { Laboratories } \\
\text { Resume Nicholas Malik, Robert Nacgele, } \\
\text { Angelo Rapa, and Herb Stevens }\end{array}$ \\
\hline 005 & 111188 & Magnifico/Harrison & Letter & $\begin{array}{l}\text { Draft ANL Revicw Report on the Deionized-Water } \\
\text { and Wastewater-Treatment Systems at the Special } \\
\text { Process Laboratorics, Ft. Meade, Maryland }\end{array}$ \\
\hline 006 & 120188 & Magnifico/Harrison & Letter & $\begin{array}{l}\text { Final ANL. Review Report on the Deionized-Water } \\
\text { and Wastewater-Treatment Systems at the Special } \\
\text { Process Laboratorics, Ft. Meade, Maryland }\end{array}$ \\
\hline 007 & 112988 & Magnifico/Harrison & Letter & $\begin{array}{l}\text { Draft ANL. Review Report on the Clean Room } \\
\text { Systems at the Special Process Laboratories, Ft. } \\
\text { Meade, Maryland }\end{array}$ \\
\hline 008 & 011189 & Merski/Harrison & Letter & $\begin{array}{l}\text { Final Report for Argonne-Conducted Periormance } \\
\text { Review of the Cleart Room Systems at the Special } \\
\text { Process Laboratory Building, Ft. Mcadic, Maryland }\end{array}$ \\
\hline 009 & 013189 & Merski/Harrison & Letler & $\begin{array}{l}\text { Revised Final ANL Report on Perlormance of the } \\
\text { Clean Room Systerns for the Special Process } \\
\text { Laboratorics, Ft. Meade, Maryland }\end{array}$ \\
\hline 010 & 020389 & Merski/Harrison & Letter & $\begin{array}{l}\text { Revised Page } 9 \text { for Final ANL Report on } \\
\text { Performance of the Clcan Room Systems for the } \\
\text { Special Process Laboratories, Ft. Meade, Maryland }\end{array}$ \\
\hline 011 & 031089 & Mcrski/Harrison & Letter & $\begin{array}{l}\text { Final ANL Report on Performance of the High- } \\
\text { Purity-Gas Piping System for the Special Process' } \\
\text { Laboratories, Ft. Meade, Maryland }\end{array}$ \\
\hline
\end{tabular}


INDEX FOR CORRESPONDENCE FILE 1.1.2 (COECO)

Documents Outgoing to USACE/BD

\begin{tabular}{lllll}
\hline COECO- Dated/Revd & To/From & Description & Subject \\
\hline 012 & 032989 & Merski/Harrison & Letter & $\begin{array}{l}\text { Final Results of ANL On-Site Review of the High- } \\
\text { Purity-Gas Piping System for the Special Process } \\
\text { Laboratories, Ft. Meade, Maryland }\end{array}$
\end{tabular}


INDEX FOR CORRESPONDENCE FILE 1.1.3 (COEI)

Documents Incoming to ANL from Other Than USACE/BD

\begin{tabular}{|c|c|c|c|c|}
\hline COEI- & Dated/Rcvd & To/From & Description & Subject \\
\hline 001 & 102688 & Harrison,Peters/Frost & Notes & $\begin{array}{l}\text { Comments on Performance Revicw of the } \\
\text { Deionization and Wastewater-Treatment Systems } \\
\text { at the NSA's Special Process Facility, Ft. Meade, } \\
\text { Maryland (Oct. } 21-22,1988 \text { ) }\end{array}$ \\
\hline 002 & 102688 & Harrison,Peters/Midkiff & Notes & $\begin{array}{l}\text { Comments on Performance Review of the } \\
\text { Deionization and Wastewater-Treatment Systems } \\
\text { at the NSA's Special Process Facility, Ft. Meade, } \\
\text { Maryland (Oct. 21-22, 1988) }\end{array}$ \\
\hline 003 & 102688 & $\begin{array}{l}\text { Harrison, Peters } \\
\text { /Collentro }\end{array}$ & Notes & $\begin{array}{l}\text { Comments on Performance Revicw of the } \\
\text { Deionization and Wastewater-Treatment Systems } \\
\text { at the NSA's Special Process Facility, Fl. Meade, } \\
\text { Maryland (Oct. 20-21, 1988) }\end{array}$ \\
\hline 004 & 110288 & Harrison/Rap̧a & Fax trans & $\begin{array}{l}\text { Resume of Mr. Angelo Rapa, Advisory Engincer, } \\
\text { of IBM General Technology Division }\end{array}$ \\
\hline 005 & 110488 & File/Harrison & Memo & $\begin{array}{l}\text { Meeting to Scope Technical Revicw of Special } \\
\text { Process Laboratories Clcan Rooms, Ft Mcade, } \\
\text { Maryland }\end{array}$ \\
\hline 006 & 101188 & File/Harrison & Memo & $\begin{array}{l}\text { Initial Mecting to Scope Performance Revicw of } \\
\text { the Deionization and Wastewater-Treatment } \\
\text { Systems, Special Process Laboratory, Fl. Meade, } \\
\text { Maryland }\end{array}$ \\
\hline 007 & 120188 & File/Harrison & Memo & $\begin{array}{l}\text { USACE response to ANL's Draft System } \\
\text { Performance Review Report on the Deionized- } \\
\text { Water and Wastewater-Treatment System at the } \\
\text { Special Process Laboratories, Fl. Meade, Maryliend }\end{array}$ \\
\hline 008 & 121688 & File/Stevens & Notes & $\begin{array}{l}\text { Notes on the } 11 / 16 / 88 \text { Technical Revicw of the } \\
\text { Clean Room Systems at the National Sccurity } \\
\text { Agency's Special Process Laboratorics, Ft. Meade, } \\
\text { Maryland }\end{array}$ \\
\hline 009 & 121688 & Harrison/Naegele & Notes & $\begin{array}{l}\text { Notes on the } 11 / 16 / 88 \text { Tectnical Revicw of the } \\
\text { Clean Room Systems at the National Security } \\
\text { Agency's Special Process Laboratories, Fl. Meade, } \\
\text { Maryland }\end{array}$ \\
\hline 010 & 121688 & Harrison/Rapa & Notes & $\begin{array}{l}\text { Notes on the } 11 / 16 / 88 \text { Technical Revicw of the } \\
\text { Clear Room Systems at the National Security } \\
\text { Agency's Special Process Laboratorics, Fl. Meade, } \\
\text { Maryland }\end{array}$ \\
\hline
\end{tabular}


INDEX FOR CORRESPONDENCE FILE 1.1.3 (COEI)

Documents Incoming to ANL from Other Than USACE/BD

\begin{tabular}{|c|c|c|c|c|}
\hline COEI- & Dated/Rcvd & To/From & Description & Subject \\
\hline 011 & 120988 & Harrison/Collentro & Signature Sheet & $\begin{array}{l}\text { Concurrence Agreement for Review of ANL Draft } \\
\text { Report of Technical Review of the Deionization } \\
\text { and Waste'vater-Treatment Systems at the National } \\
\text { Security Agency's Special Process Laboratories, } \\
\text { Ft. Meade, Maryland }\end{array}$ \\
\hline 012 & 120988 & Harrison/Frost & Signature Shect & $\begin{array}{l}\text { Concurrence Agrecment for Review of ANL Draft } \\
\text { Report of Technical Review of the Deionizat' } \\
\text { and Wastewater-Treatment Systems at the National } \\
\text { Security Agency's Special Process Laboratories, } \\
\text { Ft. Meade, Maryland }\end{array}$ \\
\hline 013 & 120988 & File/Harrison & Signature Shcet & $\begin{array}{l}\text { Concurrence Agrecment for Review of ANL Draft } \\
\text { Report of Technical Review of the Deionization } \\
\text { and Wastewater-Treatment Systems at the National } \\
\text { Security Agency's Special Process Laboratorics, } \\
\text { F. Meade, Maryland }\end{array}$ \\
\hline $0 \AA 4$ & 120988 & Harrison/Midkiff & Signature Shcet & $\begin{array}{l}\text { Concurrence Agrcernent for Revicw of ANL Draft } \\
\text { Report of Technical Revicw of the Deionization } \\
\text { and Wastewater-Treatment Systems at the National } \\
\text { Security Agency's Special Process Laboratories, } \\
\text { Ft. Meade, Maryland }\end{array}$ \\
\hline 015 & 120988 & Harrison/Peters & Signature Shect & $\begin{array}{l}\text { Concurrence Agrecment for Revicw of ANL Draft } \\
\text { Report of Technical Review of the Deionization } \\
\text { and Wastewater-Treatment Systems at the National } \\
\text { Security Agency's Special Process Laboratories, } \\
\text { Ft. Meade, Maryland }\end{array}$ \\
\hline 016 & 103188 & Harrison/Pcters & Notes & $\begin{array}{l}\text { Comments on Performance Revicw of the } \\
\text { Deionization and Wastewater-Treatment Systems } \\
\text { at the NSA's Special Process Facility, Ft. Meade, } \\
\text { Maryland (Dct. 20-21, 1988) }\end{array}$ \\
\hline 017 & 100788 & File/Harrison & Memo & $\begin{array}{l}\text { Performance Review of the High-Purity-Gas } \\
\text { Piping System at NSA's Special Process } \\
\text { Laboratories, Ft. Meade, Maryland }\end{array}$ \\
\hline 018 & 121388 & Harrison/Naegele & Signature Sheet & $\begin{array}{l}\text { Concurrence Agreement for Performance Review } \\
\text { of the Clean Room Systems at the Special Process } \\
\text { Laboratories, Fort Meade, Maryland }\end{array}$ \\
\hline 019 & 120988 & Harrison/Rapa & Signature Shect & $\begin{array}{l}\text { Concurrence Agrecment for Perlormance Revicw } \\
\text { of the Clean Room Systems at the Special Process } \\
\text { Laboratorics, Fort Meade, Maryland }\end{array}$ \\
\hline 020 & 121488 & Filc/Harrison & Signature Sheet & $\begin{array}{l}\text { Concurrence Agrecment for Performance Review } \\
\text { of the Clean Room Systems at the Special Process } \\
\text { Laboratories, Fort Meade, Maryland }\end{array}$ \\
\hline . & & & & USACE/BD Correspondence \\
\hline
\end{tabular}


INDEX FOR CORRESPONDENCE FILE 1.1.3 (COEI)

Documents Incoming to ANL from Other Than USACE/BD

\begin{tabular}{|c|c|c|c|c|}
\hline COEI- & Dated/Rcvd & To/From & Description & Subject \\
\hline 021 & 121488 & Harrison/Stevens & Signature Sheet & $\begin{array}{l}\text { Concurrence Agreement for Pelformance Rovicw } \\
\text { of the Clean Room Systems at the Special Process } \\
\text { Laboratories, Fort Meade, Maryland }\end{array}$ \\
\hline 022 & 121988 & File/Kulzer & Signature Shcet & $\begin{array}{l}\text { Assembled, Coniposite Signature Sheet: } \\
\text { Concurrence Agrecment for Performance Revicw } \\
\text { of the Clean Room Systems at the Special Process } \\
\text { Laboratorics, Fort Meade, Maryland }\end{array}$ \\
\hline 023 & 012089 & File/Harrison & Memo & $\begin{array}{l}\text { USACE-Requested Revision of Final R-port on } \\
\text { Clean Room Performance Revicw Originally } \\
\text { Submitted to USACE's Walter P. Merski on } \\
\text { January } 11,1989\end{array}$ \\
\hline 024 & 020989 & File/Harrison & Memo & $\begin{array}{l}\text { Initial Mecting to Scope Phase I Revicw (for } \\
\text { USACE) }\end{array}$ \\
\hline 025 & 101488 & Harrison/Peters & Memo & $\begin{array}{l}\text { Trip Itineraries for the Pecr Review Committec } \\
\text { (Deionization and Wastewater-Trcatment Systems } \\
\text { at Ft. Meade, Maryland) }\end{array}$ \\
\hline 026 & 100188 & File/Harrison & Memo & Signature Authorization for P. Kulycr \\
\hline 027 & 030189 & File/Harrison & Mermo & Signature Authorization For L. Narug \\
\hline 028 & 041789 & Hill/Stevens & Telecon Record & $\begin{array}{l}\text { Regarding High-Purity-Piping System and } \\
\text { Outcome of Tests by Slack Associates }\end{array}$ \\
\hline
\end{tabular}


INDEX FOR CORRESPONDENCE FILE 1.1.4 (COEO)

Documents Outgoing to Other Than USACE/BD

\begin{tabular}{|c|c|c|c|c|}
\hline COEO- & Dated/Rcvd & To/From & Description & Subject \\
\hline 001 & 101288 & Peters/Harrisun & Memo & $\begin{array}{l}\text { Session Chairmanship for Peer Review of the } \\
\text { Deionization and Wastewater-Treatment Systems } \\
\text { Located in the NSA Building at Ft. Meade, } \\
\text { Maryland }\end{array}$ \\
\hline 002 & 101488 & Frost/Harrison & Letter & $\begin{array}{l}\text { Request for Performance Revicw of the } \\
\text { Delonization and Wastewater-Treatment Systems at } \\
\text { the National Security Agency's (NSA's) Special } \\
\text { Process Facility, Fl. Meade, Maryland }\end{array}$ \\
\hline 003 & 101488 & Midkiff/Harrison & Letter & $\begin{array}{l}\text { Request for Performance Revicw of the } \\
\text { Delonization and Wastewater-Treatment Systems at } \\
\text { the National Security. Agency's (NSA's) Special } \\
\text { Process Facility, Ft. Meade, Maryland }\end{array}$ \\
\hline 004 & 101488 & Hooks/Harrison & Letter & $\begin{array}{l}\text { Request for Performance Review of the } \\
\text { Deionization and Wastewater-Treatment Systems at } \\
\text { the National Security Agency's (NSA's) Special } \\
\text { Process Facility, Ft. Meade, Maryland }\end{array}$ \\
\hline 005 & 101488 & Peters/Harrison & Memo & $\begin{array}{l}\text { Request for Performance Review of the } \\
\text { Deionization and Wastewater-Treatment Systems at } \\
\text { the National Security Agency's (NSA's) Special } \\
\text { Process Facility, Ft. Meade, Maryland }\end{array}$ \\
\hline 006 & 101988 & Collentro/Harrison & Letter & $\begin{array}{l}\text { Request for Performance Review of the } \\
\text { Deionization and Wastewater-Treatment Systems at } \\
\text { the National Security Agency's (NSA's) Special } \\
\text { Process Facility, Ft. Meade, Maryland }\end{array}$ \\
\hline 007 & 101488 & Harrison/Harrison & Letter & $\begin{array}{l}\text { Request for Performance Review of the } \\
\text { Deionization and Wastewater-Treatment Systems at } \\
\text { the National Security Agency's (NSA's) Special } \\
\text { Process Facility, Ft. Meadc, Maryland }\end{array}$ \\
\hline 008 & 102888 & Stevens/Harrison & Memo & $\begin{array}{l}\text { Session Chairmanship for Peer Review of the } \\
\text { Clean Room Systems Located in the NSA Building } \\
\text { at Ft. Meade, Maryland }\end{array}$ \\
\hline 009 & 110288 & Peters/Harrison & Memo & $\begin{array}{l}\text { Review Comments on the NSA Special Processes } \\
\text { Laboratories Deionization and Wastewater- } \\
\text { Treatment Systems, Ft. Meade, Maryland, October } \\
21-22,1988\end{array}$ \\
\hline 010 & 110788 & Stevens/Harrison & Memo & $\begin{array}{l}\text { Request for Technical Revicw of the Clean Room } \\
\text { Systems at the National Security Agency's (NSA's) } \\
\text { Special Process Laboratorics, Fl. Meade, Maryland }\end{array}$ \\
\hline
\end{tabular}


INDEX FOR CORRESPONDENCE FILE 1.1.4 (COEO)

Documents Outgoing to Other Than USACE/BD

\begin{tabular}{|c|c|c|c|c|}
\hline COEO- & Dated/Rcvd & To/From & Description & Subject \\
\hline 011 & 110788 & Harrison/Harrison & Memo & $\begin{array}{l}\text { Request for Technical Review of the Clean Room } \\
\text { Systems at the National Security Agency's (NSA's) } \\
\text { Special Process Laboratories, Ft. Meade, Maryland }\end{array}$ \\
\hline 012 & 110788 & Malik/Harrison & Memo & $\begin{array}{l}\text { Request for Technical Review of the Clean Room } \\
\text { Sysiems at the National Security Agency's (NSA's) } \\
\text { Special Process Laboratories, Fl. Meade, Maryland }\end{array}$ \\
\hline 013 & 110788 & Nagele/Harrison & Letter & $\begin{array}{l}\text { Request for Technical Review of the Clean Room } \\
\text { Systems at the National Security Agency's (NSA's) } \\
\text { Special Process Laboratories, Ft. Meade, Mz "land }\end{array}$ \\
\hline 014 & 110788 & Rapa/Harrison & Letter & $\begin{array}{l}\text { Request for Technical Revicw of the Clean Room } \\
\text { Systems at the National Security Agency's (NSA's) } \\
\text { Special Process Laboratorics, Fl. Meide, Maryland }\end{array}$ \\
\hline 015 & 111188 & Peters/Harrison & Memo & $\begin{array}{l}\text { Concurrence Review of Draft ANL Report on the } \\
\text { Deionized-Water and Wastewater-Treatment } \\
\text { Systerns at the Special Process Laboratorics, Fl. } \\
\text { Meade, Maryland }\end{array}$ \\
\hline 016 & 111188 & Collentro/Harrison & Letter & $\begin{array}{l}\text { Concurrence Review of Draft ANL Report on the } \\
\text { Deionized-Water and Wastewater-Treatment } \\
\text { Systems at the Special Process Laboratorics, Fl. } \\
\text { Meade, Maryland }\end{array}$ \\
\hline 017 & 111188 & Midkiff/Harrison & Letter & $\begin{array}{l}\text { Concurrence Review of Draft ANL Report on the } \\
\text { Deionized-Water and Wastewater-Treatment } \\
\text { Systems at the Special Process Laboratories, Ft. } \\
\text { Meade, Maryland }\end{array}$ \\
\hline 018 & 111188 & Frost/Harrison & Letter & $\begin{array}{l}\text { Concurrence Review of Draft ANL Report on the } \\
\text { Deionized-Water and Wastewater-Treatment } \\
\text { Systems at the Special Process Laboratorics, Ft. } \\
\text { Meade, Maryland }\end{array}$ \\
\hline 019 & 111188 & Harrison/Harrison & Merno & $\begin{array}{l}\text { Concurrence Review of Draft ANL Report on the } \\
\text { Deionized-Water and Wastewater.Treatment } \\
\text { Systemis at the Special Process Laboratories, Ft. } \\
\text { Meade, Marytand }\end{array}$ \\
\hline$(020$ & 112988 & Nacgele/Harrison & Letter & $\begin{array}{l}\text { Concurrence Revicw of Draft ANL. Report on the } \\
\text { Clean Room Systems at the Special Process } \\
\text { Laboratories, Ft. Mcade, Maryland }\end{array}$ \\
\hline 021 & 112988 & Rapa/Harrisun & Letter & $\begin{array}{l}\text { Concurrence Review of Dralt ANL Report on the } \\
\text { Clean Room Systems at the Special Process } \\
\text { Laboratories, Ft. Meade, Maryland }\end{array}$ \\
\hline
\end{tabular}


INDEX FOR CORRESPONDENCE FILE 1.1.4 (COEO)

Documents Outgoing to Other Than USACE/BD

\begin{tabular}{|c|c|c|c|c|}
\hline COEO- & Dated/Rcvd & To/From & Description & Subject \\
\hline 022 & 112988 & Harrison/Harrison & Memo & $\begin{array}{l}\text { Concurrence Review of Draft ANL Report on the } \\
\text { Clean Room Systems at the Special Process } \\
\text { Laboratories, Ft. Meade, Maryland }\end{array}$ \\
\hline 023 & 112988 & Malik/Harrison & Memo & $\begin{array}{l}\text { Concurrence Review of Draft ANL Report on the } \\
\text { Clean Room Systems at the Special Process } \\
\text { Laboratories, Ft. Meade, Maryland }\end{array}$ \\
\hline 024 & 112988 & Stevens/Harrison & Memo & $\begin{array}{l}\text { Concurrence Review of Draft ANL Report on the } \\
\text { Clean Room Systems at the Special Process } \\
\text { Laboratories, Ft. Meade, Maryland }\end{array}$ \\
\hline 025 & $02 n 989$ & Nolan/Harrison & Letter & $\begin{array}{l}\text { Request for Technical Review of the High-Purity- } \\
\text { Gas Piping Uystem at the National Security } \\
\text { Agency's Special Process Laboratories (SPL), Ft. } \\
\text { Meade, Maryland (copy of COEI-017 altached) }\end{array}$ \\
\hline 026 & 020989 & Stevens/Harrison & Memo & $\begin{array}{l}\text { Request for Technical Review of the High-Purity- } \\
\text { Gas Piping System at the National Security } \\
\text { Agency's Special Process Laboratories (SPL), Fi. } \\
\text { Meade, Maryland (copy of COEI-017 atlached) }\end{array}$ \\
\hline 027 & 020989 & Engelkemeir/Harrison & Memo & $\begin{array}{l}\text { Request for Technical Review of the High-Purity- } \\
\text { Gas Piping System at the National Security } \\
\text { Agency's Special Process Laboratorics (SPL), Fl. } \\
\text { Meade, Maryland (copy of COEI-017 attached) }\end{array}$ \\
\hline 028 & 020989 & Harrison/Harrison & Memo & $\begin{array}{l}\text { Request for Technical Revicw of the High-Purity- } \\
\text { Gas Piping System at the National Security } \\
\text { Agency's Special Process Laboratorics (SPL), Ft. } \\
\text { Merde, Maryland (copy of COEI-()17 attached)y }\end{array}$ \\
\hline 029 & 021789 & Engelkemeir/Stevens & Memo & $\begin{array}{l}\text { High-PurityProcess Piping Tests .. Recent } \\
\text { Information }\end{array}$ \\
\hline 030 & 021789 & Malik/Stevens & Memo & $\begin{array}{l}\text { High-PurityProcess Piping Tests -. Recent } \\
\text { Information }\end{array}$ \\
\hline 031 & 021789 & Stoy/Stevens & Letter & $\begin{array}{l}\text { High-PurityProcess Piping Tests _.. Recent } \\
\text { Information }\end{array}$ \\
\hline 032 & 021789 & Nolan/Stevens & Letter & $\begin{array}{l}\text { Performance Review of the High-Purity-Gas Piping } \\
\text { System at the National Security Agency's Special } \\
\text { Process Laboratorics, Fl. Mcade, Maryland } \\
\text { (background information); and High-Purity Process } \\
\text { Piping Tests -- Recent Information (Specifications } \\
\text { altached) }\end{array}$ \\
\hline 033 & 031389 & File/Harrison & Memo & $\begin{array}{l}\text { Disposition of March 9, 1989, Letter Report to P. } \\
\text { Merski }\end{array}$ \\
\hline
\end{tabular}


$15 / 16$

\subsection{USACE/BD-Sponsored Formal Reviews}




\section{INDEX OF DOCUMENTS PERTAINING TO THE USACE/BD-SPONSORED FORMAL PERFORMANCE REVIEW OF THE CLEA' ROOM SYSTEMS AT THE SPECIAL PROCESS LABORATORIES BUILDING, FT. MEADE, MARYLAND 1.2 .1}

\begin{tabular}{|c|c|c|c|c|}
\hline FILE- & Dated/Rcvd & To/From & Description & Subject \\
\hline COEO-008 & 102888 & Stevens/Harrison & Memo & $\begin{array}{l}\text { Session Chairmanship for Peer Revicw of the } \\
\text { Clean Room Systems Located in the NSA Building } \\
\text { at Ft. Meade, Maryland }\end{array}$ \\
\hline COEI-004 & 110388 & Harrison/Rapa & Fax trans & $\begin{array}{l}\text { Resume of Mr. Angelo Rapa, Advisory Engineer, } \\
\text { of IBM General Technology Division }\end{array}$ \\
\hline COECO-004 & 110388 & Magnifico/Harrison & Letter & $\begin{array}{l}\text { NSA Area Office Concurrence with ANL's } \\
\text { Selection of Panelists or Revicw of Performance of } \\
\text { Clean Room Systems in the Special Process } \\
\text { Laboratories }\end{array}$ \\
\hline COEI-005 & 110488 & File/Harrison & Memo & $\begin{array}{l}\text { Meeting to Scope Technical Revicw of Special } \\
\text { Process Laboratories Clcan Rooms, Fl. Mcade, } \\
\text { Maryland }\end{array}$ \\
\hline COEO-010 & 110788 & Stevens/Harrison & Memo & $\begin{array}{l}\text { Request for Technical Review of the Clcan Room } \\
\text { Systems at the National Security Agency's (NSA's) } \\
\text { Special Process Laboratories, Ft. Meadc, Maryland }\end{array}$ \\
\hline COEO-011 & 110788 & Harrison/Harrison & Memo & $\begin{array}{l}\text { Request for Technical Review of the Clcan Room } \\
\text { Systems at the National Security Agency's (NSA's) } \\
\text { Special Process Laboratorics, Ft. Meadc, Maryland }\end{array}$ \\
\hline COEO-012 & 110788 & Malik/Harrison & Memo & $\begin{array}{l}\text { Request for Technical Revicw of the Clean Room } \\
\text { Systems at the National Security Agency's (NSA's) } \\
\text { Special Process Laboratories, Ft. Meadc, Maryland }\end{array}$ \\
\hline COEO-013 & 110788 & Naegele/Harrison & Letter & $\begin{array}{l}\text { Request for Technical Revicw of the Clcan Room } \\
\text { S'jutems at the National Security Agency's (NSA's) } \\
\text { Special Process Laboratories, Ft. Meadc, Maryland }\end{array}$ \\
\hline COEO-014 & 110788 & Rapa/Harrison & Letter & $\begin{array}{l}\text { Request for Technical Revicw of the Clean Room } \\
\text { Systems at the National Security Agency's (NSA's) } \\
\text { Special Process Laboratories, Ft. Meadc, Maryland }\end{array}$ \\
\hline COEO- 020 & 112988 & Naegele/Harrison & Letter & $\begin{array}{l}\text { Concurrence Review of Draft ANL Report on the } \\
\text { Clean Room Systems at the Special Process } \\
\text { Laboratorics, Ft. Meade, Maryland }\end{array}$ \\
\hline COEO-021 & 112988 & Rapa/Harrison & Letter & $\begin{array}{l}\text { Concurrence Review of Draft ANL Report on the } \\
\text { Clean Room Systems at the Special Process } \\
\text { Laboratories, Ft. Meade, Maryland }\end{array}$ \\
\hline COEO-022 & 112988 & Harrison/Harrison & Memo & $\begin{array}{l}\text { Concurrence Revicw of Draft ANL Report on the } \\
\text { Clean Room Systems at the Special Process } \\
\text { Laboratories, Ft. Meade, Maryland }\end{array}$ \\
\hline
\end{tabular}




\section{INDEX OF DOCUMENTS PERTAINING TO THE USACE/BD-SPONSORED FORMAL PERFORMANCE REVIEW OF THE CLEAN ROOM SYSTEMS AT THE SPECIAL PROCESS LABORATORIES BUILDING, FT. MEADE, MARYLAND 1.2 .1}

\begin{tabular}{|c|c|c|c|c|}
\hline FILE- & Dated/Rcvd & To/From & Description & Subject \\
\hline COEO-023 & 112988 & Malik/Harrison & Memo & $\begin{array}{l}\text { Concurrence Review of Draft ANL Report on the } \\
\text { Clean Room Systems at the Special Process } \\
\text { Laboratories, Ft. Meade, Maryland }\end{array}$ \\
\hline COEO-024 & 112988 & Stevens/Harrison & Memo & $\begin{array}{l}\text { Concurrence Review of Draft ANL Report on the } \\
\text { Clean Room Systems at the Special Process } \\
\text { Laboratorics, Ft. Mcade, Maryland }\end{array}$ \\
\hline COECO-007 & 112988 & Magnifico/Harrison & Letter & $\begin{array}{l}\text { Draft ANL Review Report on the Clean Room } \\
\text { Systems at the Special Process Laboratorics, Ft. } \\
\text { Meade, Maryland }\end{array}$ \\
\hline COEI-019 & 120988 & File & Signature Shcet & $\begin{array}{l}\text { Concurrence Agreement for Performance Revicw of } \\
\text { the Clean Room Systems at the Special Process } \\
\text { Laboratories, Fort. Meade, Maryland }\end{array}$ \\
\hline COECI-003 & 121288 & Harrison/Merski & Letter & $\begin{array}{l}\text { Integrated Clean Room Systems Revicw Panclists, } \\
\text { (TP 13040), Special Process Laboratorics, National } \\
\text { Security Agency, Ft. Meade, Maryland } \\
\text { (Concurrence with ANL Selection of Panclists) }\end{array}$ \\
\hline COEI-018 & 121388 & File & Signature Sheet & $\begin{array}{l}\text { Concurrence Agreement for Performance Revicw of } \\
\text { the Clean Room Systems at the Special Process } \\
\text { Laboratories, Fort. Mcade, Maryland }\end{array}$ \\
\hline COEI-020 & 121488 & File & Signature Sheet & $\begin{array}{l}\text { Concurrence Agrcement for Performance Revicw of } \\
\text { the Clean Room Systems at the Special Process } \\
\text { Laboratories, Fort. Meade, Maryland }\end{array}$ \\
\hline COEI-021 & 121488 & File & Signature Shect & $\begin{array}{l}\text { Concurrence Agreement for Performance Revicw of } \\
\text { the Clean Room Systems at the Special Process } \\
\text { Laboratorics, For. Meade, Maryland }\end{array}$ \\
\hline COEI-008 & 121688 & File/Stevens & Notes & $\begin{array}{l}\text { Notes on the } 11 / 16 / 88 \text { Technical Revicw of the } \\
\text { Clean Room Systems at the National Security } \\
\text { Agency's Special Process Laboratories, Ft. Meade, } \\
\text { Maryland }\end{array}$ \\
\hline COEI-009 & 121688 & File/Naegele & Notes & $\begin{array}{l}\text { Notes on the } 11 / 16 / 88 \text { Technical Review of the } \\
\text { Clean Room Systems at the National Security } \\
\text { Agency's Special Process Laboratories, Fl. Mcalde, } \\
\text { Maryland }\end{array}$ \\
\hline COEI-010 & 121688 & File/Rapa & Notes & $\begin{array}{l}\text { Notes on the } 11 / 16 / 88 \text { Technical Review of the } \\
\text { Clean Room Systems at the National Security } \\
\text { Agency's Special Process Laboratorics, Ft. Meade, } \\
\text { Maryland }\end{array}$ \\
\hline
\end{tabular}


INDEX OF DOCUMENTS PERTAINING TO THE USACE/BD-SPONSORED FORMAL. PERFORMANCE REVIEW OF THE CLEAN ROOM SYSTEMS AT THE SPECIAL PROCESS

LABORATORIES BUILDING, FT. MEADE, MARYLAND 1.2 .1

\begin{tabular}{|c|c|c|c|c|}
\hline FILE- & Dated/Rcvd & To/From & Description & Subject \\
\hline COEI-022 & 121988 & File & Signature Sheet & $\begin{array}{l}\text { Composite Sheet: Concurrence Agrecment for } \\
\text { Performance Review of the Clean Room Systems } \\
\text { at the Special Process Laboratory Building, Ft. } \\
\text { Meade, Maryland }\end{array}$ \\
\hline COECO-008 & 011189 & Merski/Harrison & Letter & $\begin{array}{l}\text { Final Report for Argonne-Conducted Performance } \\
\text { Review of the Clean Room Systems at the Special } \\
\text { Process Laboratory Building, Ft. Mcade, Maryland }\end{array}$ \\
\hline COEI.023 & 012089 & File/Harrison & Memo & $\begin{array}{l}\text { USACE-Requested Revisions of Final Report on } \\
\text { Clean Room Performance Review Originally } \\
\text { Submitted to USACE's Walter P. Merski on } \\
\text { January } 11,1989\end{array}$ \\
\hline COECO-009 & 013189 & Merski/Harrison & Letter & $\begin{array}{l}\text { Revised Final ANL Report on Performance of the } \\
\text { Clean Room Systems for the Special Process } \\
\text { Laboratories, Ft. Meade, Maryland }\end{array}$ \\
\hline COECO-010 & 020389 & Merski/Harrison & Letter & $\begin{array}{l}\text { Revised Final AN, Report on Performance of the } \\
\text { Clean Room Systems for the Special Process } \\
\text { Laboratories, Ft. Meade, Maryland }\end{array}$ \\
\hline
\end{tabular}




\section{INDEX OF DOCUMENTS PERTAINING TO THE USACE/BD-SPONSORED FORMAL PERFORMANCE REVIEW OF THE DEIONIZED-WATER AND WASTEWATER-TREATMENT SYSTEMS AT THE SPECIAL PROCESS LABORATORIES, FT. MEADE, MARYLAND 1.2 .2}

\begin{tabular}{|c|c|c|c|c|}
\hline FILE- & Dated/Rcvd & To/From & Description & Subject \\
\hline COEI-006 & 101188 & File/Harrison & Memo & $\begin{array}{l}\text { Initial Meeting to Scope Performance Revicw of the } \\
\text { Deionization and Wastewater-Treatment Systems, } \\
\text { Special Process Laboratory, Ft. Meade, Maryland }\end{array}$ \\
\hline COEO-001 & 101288 & Peters/Harrison & Memo & $\begin{array}{l}\text { Session Chairmanship for Pecr Revicw of the } \\
\text { Deionization and Wastewater-Treatment Systems } \\
\text { Located in the NSA Building at FL. Meade, Maryland }\end{array}$ \\
\hline COEI-025 & 101488 & Harrison/Peters & Memo & $\begin{array}{l}\text { Trip Itineraries for Peer Review Committee } \\
\text { (Deionization and Wastewater-Treatment Systems at. } \\
\text { Ft. Meade, Maryland) }\end{array}$ \\
\hline COEO-002 & 101488 & Frost/Harrison & Letter & $\begin{array}{l}\text { Request for Performance Revicw of the Deionization } \\
\text { and Wastewater-Treatment Systems at the National } \\
\text { Security Agency's (NSA's) Special Process Facility, } \\
\text { Ft. Meade, Maryland }\end{array}$ \\
\hline COEO-003 & 101488 & Midkiff/Harrisun & Letter & $\begin{array}{l}\text { Request for Performance Review of the Deionization } \\
\text { and Wastewater-Treatment Systems at the National } \\
\text { Security Agency's (NSA's) Special Process Facility, } \\
\text { Ft. Meade, Maryland }\end{array}$ \\
\hline COEO-004 & 101488 & Hooks/Harrison & Leller & $\begin{array}{l}\text { Request for Performance Revicw of the Deioniration } \\
\text { and Wastewater-Treatment Systems at the National } \\
\text { Security Agency's (NSA's) Special Process Facility, } \\
\text { Ft. Meade, Maryland }\end{array}$ \\
\hline COEO-005 & 101488 & Peters/Harrison & Memo & $\begin{array}{l}\text { Request for Performance Revicw of the Deionization } \\
\text { and Wastewater-Treatment Systems at the National } \\
\text { Security Agency's (NSA's) Special Process Facility, } \\
\text { Ft. Meade, Maryland }\end{array}$ \\
\hline COECO-002 & 101488 & Magnifico/Harrison & Letter & $\begin{array}{l}\text { NSA Area Office Concurrence with ANL's Selection } \\
\text { of Panelists for Review of Pcrformance of } \\
\text { Deionization and Wastewater-Treatment Systems }\end{array}$ \\
\hline COECO-003 & 101988 & Magnifico/Harrison & Letter & $\begin{array}{l}\text { NSA Area Office Concurrence with ANL's Selection } \\
\text { of Mr. William Collentro as a panclist for Review of } \\
\text { Performance of Deionization and Wastewater- } \\
\text { Treatment Systems }\end{array}$ \\
\hline COEO-007 & 101488 & Harrison/Harrison & Letter & $\begin{array}{l}\text { Request for Performance Review of the Deionization } \\
\text { and Wastewater-Treatment Systems at the National } \\
\text { Security Agency's (NSA's) Special Process Facility, } \\
\text { FL. Meade, Maryland }\end{array}$ \\
\hline \multirow[t]{2}{*}{ COEO-006 } & 101988 & Collentro/Harrison & Lelter & $\begin{array}{l}\text { Request for Performance Review of the Deionization } \\
\text { and Wastewater-Treatment Systems at the National } \\
\text { Security Agency's (NSA's) Special Processi Facility, } \\
\text { Fl. Meade, Mary'and }\end{array}$ \\
\hline & & & & $\begin{array}{l}\text { USACE/BD-Sponsored Formal Review } \\
\text { Deionized-Wuier and Wastewater-Preciment Syotem }\end{array}$ \\
\hline
\end{tabular}


INDEX OF DOCUMENTS PERTAINING TO THE USACE/BD-SPONSORED FORMAL PERFORMANCE REVIEW OF THE DEIONIZED-WATER AND WASTEWATER-TREATMENT SYSTEMS AT THE SPECIAL PROCESS LABORATORIES, FT. MEADE, MARYLAND 1.2 .2

\begin{tabular}{|c|c|c|c|c|}
\hline FILE- & Dated/Rcvd & To/From & Description & Subject \\
\hline COEI-001 & 102688 & Harrison,Peters/Frost & Notes & $\begin{array}{l}\text { Comments on Performance Review of the } \\
\text { Deionization and Wastewater-Treatment Systems at } \\
\text { the NSA's Special Process Facility, Fl. Meade, } \\
\text { Maryland (Oct. } 21-22,1988 \text { ) }\end{array}$ \\
\hline COEI-002 & 102688 & Harrison,Peters/Frost & Notes & $\begin{array}{l}\text { Comments on Performance Review of the } \\
\text { Deionization and Wastewater-Treatment Systerrs at } \\
\text { the NSA's Special Process Facility, Fl. Meade, } \\
\text { Maryland (Oct. 21-22, 1988) }\end{array}$ \\
\hline COEI-003 & 102688 & $\begin{array}{l}\text { Harrison,Peters } \\
\text { /Collentro }\end{array}$ & Notes & $\begin{array}{l}\text { Comments on Performance Review of the } \\
\text { Deionization and Wastewater-Treatment Systems at } \\
\text { the NSA's Special Process Facility, Fl. Meade, } \\
\text { Maryland (Oct. 21-22, 1988) }\end{array}$ \\
\hline COEI-016 & 103188 & Harrison/Peters & Notes & $\begin{array}{l}\text { Comments on Performance Review of the } \\
\text { Deionization and Wastewater-Treatment Systems at } \\
\text { the NSA's Special Process Facility, Ft. Meade, } \\
\text { Maryland (Oct. } 21-22,1988 \text { ) }\end{array}$ \\
\hline COEO-009 & 110288 & Peters/Harrison & Memo & $\begin{array}{l}\text { Review Comments on the NSA Special Process } \\
\text { Laboratories Deionization and Wastewater-Treatment } \\
\text { Systems, Ft. Meade, Maryland, October } 20 / 21,1988\end{array}$ \\
\hline COEO-015 & 111188 & Peters/Harrison & Memo & $\begin{array}{l}\text { Concurrence Review of Draft ANL. Report on the } \\
\text { Deionized-Water and Wastewater-Treatment Systems } \\
\text { at the Special Process Laboratorics, Fl. Meade, } \\
\text { Maryland }\end{array}$ \\
\hline COEO-016 & 111188 & Collentro/Harrison & Letter & $\begin{array}{l}\text { Concurrence Review of Draft ANL Report on the } \\
\text { Deionized-Water and Wastewater-Treatment Systems } \\
\text { at the Special Process Laboratories, Ft. Meade, } \\
\text { Maryland }\end{array}$ \\
\hline COEO-017 & 111188 & Midkiff/Harrison & Letter & $\begin{array}{l}\text { Concurrence Review of Draft ANL Report on the } \\
\text { Deionized-Water and Wastewater-Treatument Systems } \\
\text { at the Special Process Laboratories, Fl. Meade, } \\
\text { Maryland }\end{array}$ \\
\hline COEO-018 & 111188 & Frost/Harrison & Letter & $\begin{array}{l}\text { Concurrence Review of Draft ANL Report on the } \\
\text { Deionized-Water and Wastewater-Treatment Systems } \\
\text { at the Special Process Laboratorics, Fl. Meade, } \\
\text { Maryland }\end{array}$ \\
\hline COEO-019 & 111188 & Harrison/Harrison & Memo & $\begin{array}{l}\text { Concurrence Review of Draft ANL Report on the } \\
\text { Deionized-Water and Wastewater-Treatment Systems } \\
\text { at the Special Process Laboratories. Ft. Meade, } \\
\text { Maryland }\end{array}$ \\
\hline
\end{tabular}


INDEX OF DOCUMENTS PERTAINING TO THE USACE/BD-SPONSORED FORMAL PERFORMANCE REVIEW OF THE DEIONIZED-WATER AND WASTEWATER-TREATMENT SYSTEMS AT THE SPECIAL PROCESS LABORATORIES, FT. MEADE, MARYLAND 1.2 .2

\begin{tabular}{|c|c|c|c|c|}
\hline FILE- & Dated/Rcvd & To/From & Description & Subject \\
\hline COECO-005 & 111188 & Magnifico/Harrison & Letter & $\begin{array}{l}\text { Draft ANL Review Report on the Deionized-Wator } \\
\text { and Wastewater-Treatment Systems at the Special } \\
\text { Process Laboratories, Ft. Meade, Maryland }\end{array}$ \\
\hline COEI-007 & 120188 & File/Harrison & Memo & $\begin{array}{l}\text { USACE Response to ANL's Draft Performance } \\
\text { Review Report on the Deionized-Water and } \\
\text { Wastewater-Treatment System at the Special Process } \\
\text { Laboratories, Ft. Meade, Maryland }\end{array}$ \\
\hline COECO-006 & 120188 & Magnifico/Harrison & Letter & $\begin{array}{l}\text { Final ANL Review Report on the Deionized-Water } \\
\text { and Wastewater-Treatment Systems at the Special } \\
\text { Process Laboratories, Ft. Meade, Maryland }\end{array}$ \\
\hline COECI-002 & 120888 & Harrison/Merski & Letter & $\begin{array}{l}\text { Deionized-Water and Industrial Waste Treatment } \\
\text { Systems Review Panclists (TP's } 1124(0,1139()) \text { SPL, } \\
\text { NSA, Ft. Meade, Maryland (Concurrence with ANL } \\
\text { Selection of Panclists) }\end{array}$ \\
\hline COEI-011 & 120988 & File & $\begin{array}{l}\text { Signature } \\
\text { Sheet }\end{array}$ & $\begin{array}{l}\text { Concurrence Agrecment for Review of ANL Draft } \\
\text { Report of Technical Review of the Deionization and } \\
\text { Wastewater-Treatment Systems at the National } \\
\text { Security Agency's Special Process Laboratories, Ft. } \\
\text { Meade, Maryland }\end{array}$ \\
\hline COEI-012 & 120988 & File & $\begin{array}{l}\text { Signature } \\
\text { Shcet }\end{array}$ & $\begin{array}{l}\text { Concurrence Agreement for Review of ANL Draft } \\
\text { Report of Technical Revicw of the Deionization and } \\
\text { Wastewater-Treatment Systems at the National } \\
\text { Security Agency's Special Process Laboratorics, Fl. } \\
\text { Meade, Maryland }\end{array}$ \\
\hline COEI-013 & 120988 & File & $\begin{array}{l}\text { Signature } \\
\text { Shcet }\end{array}$ & $\begin{array}{l}\text { Concurrence Agrecment for Review of ANL Draft } \\
\text { Report of Technical Review of the Deionization and } \\
\text { Wastewater-Treatment Systems at the National } \\
\text { Security Agency's Special Process Laboratories, Ft. } \\
\text { Meade, Maryland }\end{array}$ \\
\hline COEI-014 & 120988 & File & $\begin{array}{l}\text { Signature } \\
\text { Sheet }\end{array}$ & $\begin{array}{l}\text { Concurrence Agreement for Review of AN! Draft } \\
\text { Report of Technical Review of the Deionization and } \\
\text { Wastewater-Treatment Systems at the National } \\
\text { Security Agency's Special Process Laboraltorics, Fl. } \\
\text { Meade, Maryland }\end{array}$ \\
\hline COEI-015 & 120988 & File & $\begin{array}{l}\text { Signaturc } \\
\text { Shcet }\end{array}$ & $\begin{array}{l}\text { Concurrence Agreement for Review of ANL. Dralt } \\
\text { Report of Technical Review of the Deionization and } \\
\text { Wastewater-Treatment Systems at the National } \\
\text { Security Agency's Special Process Laboratorics, Fl. } \\
\text { Meade, Maryland }\end{array}$ \\
\hline
\end{tabular}


INDEX OF DOCUMENTS PERTAINING TO THE USACE/BD.SPONSORED SPECIAL ON-SITE REVIEW OF THE HIGH-PURITY-GAS PIPING SYSTEMS, SPL BUILDING, FT. MEADE, MARYLAND

1.2 .3

\begin{tabular}{|c|c|c|c|c|}
\hline FILE- & Dated/Rcvd & To/From & Description & Subject \\
\hline COECO.001 & 100488 & Magnifico/Harrison & Letter & $\begin{array}{l}\text { NSA Area Office Concurrence with ANL's } \\
\text { Selection of Panelists for Revlew of } \\
\text { Performance of High-Purily-Gas Piping } \\
\text { Systems }\end{array}$ \\
\hline COEI-017 & 100788 & Filc/Harrison & Memo & $\begin{array}{l}\text { Performance Review of the High-Purity-Gas } \\
\text { Piping System at NSA's Special Process } \\
\text { Laboratories, Ft. Meade, Maryland }\end{array}$ \\
\hline COECI-001 & 112988 & Harrison/Merski & Letter & $\begin{array}{l}\text { Special Gas and Liquid Distribution Systems } \\
\text { Review Panelists, SPL, NSA, Ft. Meade, } \\
\text { Maryland (Concurrence with ANL Selection } \\
\text { of Panclists) }\end{array}$ \\
\hline COEI-(024 & 020989 & File/Harrison & Memo & $\begin{array}{l}\text { Initial Meeting to Scope Phase I Review (for } \\
\text { USACE) }\end{array}$ \\
\hline COEO-025 & 020989 & Nolen/Harrison & Letter & $\begin{array}{l}\text { Request for Technical Review of the High- } \\
\text { Purity-Gas Piping System at the National } \\
\text { Security Agency's Special Process } \\
\text { Laboratorics }\end{array}$ \\
\hline COEO-026 & 020989 & Stevens/Harrison & Memo & $\begin{array}{l}\text { Request for Technical Review of the High- } \\
\text { Purity-Gas Piping System at the National } \\
\text { Security Agency's Special Process } \\
\text { Laboratories }\end{array}$ \\
\hline COEO-027 & 020989 & Engelkemcir/Harrison & Memo & $\begin{array}{l}\text { Request for Technical Review of the High- } \\
\text { Purity-Gas Piping System at the National } \\
\text { Security Agency's Special Process } \\
\text { Laboratories }\end{array}$ \\
\hline COEO-028 & 020989 & Harrison/Harrison & Memo & $\begin{array}{l}\text { Request for Technical Review of the High- } \\
\text { Purity-Gas Piping System at the National } \\
\text { Security Agency's Special Process } \\
\text { Laboratories }\end{array}$ \\
\hline COEO-029 & 021789 & Engelkemeir/Stevens & Memo & $\begin{array}{l}\text { High-Purity Process Piping Tests -- Recent } \\
\text { Information }\end{array}$ \\
\hline COEO-030 & 021789 & Malik/Stevens & Memo & $\begin{array}{l}\text { High-Purity Process Piping Tests .. Recent } \\
\text { Information }\end{array}$ \\
\hline COEO-031 & 021789 & Stoy/Stevens & Letter & $\begin{array}{l}\text { High-Purity Process Piping Tests -- Recent } \\
\text { Information }\end{array}$ \\
\hline
\end{tabular}


INDEX OF DOCUMENTS PERTAINING TO THE USACE/BD-SPONSORED SPECIAL ON-SITE REVIEW OF THE HIGH.PURITY-GAS PIPING SYSTEMS, SPL BUILDING,

FT. MEADE, MARYLAND

1.2 .3

\begin{tabular}{|c|c|c|c|c|}
\hline FILE- & Dated/Rcvd & To/From & Description & Subjcct \\
\hline COEO-032 & 021789 & Nolen/Stevens & Letter & $\begin{array}{l}\text { Performarice Review of the High-Purity-Gas } \\
\text { Piping System at the National Security } \\
\text { Agency's Special Process Laboratories, Fi. } \\
\text { Meade, Maryland (background information); } \\
\text { and High-Purity Process Piping Tests -- } \\
\text { Recent Information }\end{array}$ \\
\hline COEI-026 & 030189 & File/Harrison & Letter & Signature Authorization for P. Kulzor \\
\hline COECO-011 & 031089 & Merski/Harrison & Lotter & $\begin{array}{l}\text { Results of Argonne's On-Site Review of the } \\
\text { High-Purity-Gas Piping System at the } \\
\text { Special Process Laboratorics Building, Ft. } \\
\text { Meade, MD }\end{array}$ \\
\hline COEI-027 & 031589 & File/Harrison & Letler & Signature Authorization for L. Narug \\
\hline COECO-012 & 032989 & Merski/Harrison & Letter & $\begin{array}{l}\text { Final Results of Argonne's On-Site Review } \\
\text { of the High-Purity-Gas Piping System at the } \\
\text { Special Process Laboratorics Building, Ft. } \\
\text { Meade, MD }\end{array}$ \\
\hline
\end{tabular}




\section{$25 / 26$}

1.3 Index of Documents Pertaining to National Security Agency (NSA)-Sponsored Formal and Informa" Reviews 
INDEX FOR CORRESIPONDENCE FILE 1.3.1 (NSAIN)

Documents Incoming to ANL from NSA

\begin{tabular}{|c|c|c|c|c|}
\hline NSAIN- & Dated/Rovd & To/From & Description & Subject \\
\hline 001 & 022789 & Harrtson/Soule & Letter & $\begin{array}{l}\text { Review of panclists for the performance } \\
\text { reviews of Phase II enhancements to the } \\
\text { Special Process Laboratories, Fit. Meade, } \\
\text { MD }\end{array}$ \\
\hline 002 & 042089 & File/NSA & Report & $\begin{array}{l}\text { National Semiconductor Construction } \\
\text { Schedule }(4-4-89)\end{array}$ \\
\hline 003 & 052289 & File/NSA & Specifications & $\begin{array}{l}\text { National Scmiconductor - Ft. Moude (7 } \\
\text { total) }\end{array}$ \\
\hline \multirow[t]{2}{*}{004} & \multirow[t]{2}{*}{080989} & \multirow[t]{2}{*}{ Kokalis/Quinlivan } & & $\begin{array}{l}\text { Lepco's response to deficiencies delined by } \\
\text { ANL }\end{array}$ \\
\hline & & & Attachment & $\begin{array}{l}\text { Minutes of NSA/NSC Construction } \\
\text { Meeting: } \\
\text { Date/Time: August } 8,1989 / 1:(0) \mathrm{pm} \\
\text { Ft. Meade, MD } \\
\text { RE; Ft. Meade MEBES Facility }\end{array}$ \\
\hline \multirow[t]{3}{*}{005} & \multirow[t]{3}{*}{081489} & Kokalis/Quinlivan & Letter & $\begin{array}{l}\text { Marshall Contractors defining Duct } \\
\text { Testing Requirements }\end{array}$ \\
\hline & & \multirow[t]{2}{*}{ Jackman/Jansen } & $\begin{array}{l}\text { Altachment } \\
\text { Attachment }\end{array}$ & $\begin{array}{l}\text { RE: Testing of Ductwork } \\
\text { AABC Technical Papers - Duct Leakagc } \\
\text { and Air Balancing (Publication) }\end{array}$ \\
\hline & & & Altachment & $\begin{array}{l}\text { United McGill Leakage Test Kits (Product } \\
\text { Litcrature) }\end{array}$ \\
\hline 006 & 090789 & Shepard/Cunningham & Memo & $\begin{array}{l}\text { Review of ANL's Specifications on the } \\
\text { Multi-Media Prefilter }\end{array}$ \\
\hline 007 & 091489 & Kokalis/Cunningham & Letter & High-Purity Piping Services \\
\hline 008 & 091889 & Kokalis/Cunningham & Letter & $\begin{array}{l}\text { D.I. Water-Treatment System } \\
\text { Enhancements }\end{array}$ \\
\hline 009 & 091889 & Kokalis/Cunningham & Letter & Sprinkler System Calculation Review \\
\hline
\end{tabular}

Closed February 1990. Continuation in NSAIN Log"A" 
INDEX FOR CORRESPONDENCE FII.

Documents Incoming to ANL frim NSA

\begin{tabular}{lllll}
\hline NSAIN- & Dated/Rcvd & To/From & Description & Subject \\
\hline 010 & 010390 & File & Minutes & Contractor Coordinator Mecting, 12 December 1989 \\
011 & 0103890 & File & Minutes & Contractor Coordinator Meeting, 6 December 1989 (Revised) \\
012 & 010390 & File & Minutes & Contractor Coordinator Mecting, 6 Decernber 1989) \\
013 & 011590 & File & Minutes & Contractor Coordination Mceting, 19 December 1989) \\
014 & 011590 & File & Minutes & Contractor Coordination Mecting, 03 January 1990) \\
015 & 011590 & File & Minutes & Contractor Coordination Mecting, 9 January 1990) \\
016 & $011690 / 012990$ & File & Minutes & Contractor Coordination Mecting, 16 January 1990) \\
017 & $020690 / 022390$ & File & Minutes & Contractor Coordination Mecting, 6 February 1990)
\end{tabular}


INDEX FOR CORRESPONDENCE FILE 1.3.3 (NSAIO)

Documents Incoming to ANL from Other Than NSA

\begin{tabular}{|c|c|c|c|c|}
\hline NSAIO- & Dated/Rcrd & To/From & Description & Subject \\
\hline 001 & 020389 & File/Harrison & Memo & Scoping the Technical Reviow \\
\hline 002 & 020189 & NSA File/Harrison & Mermo & Signature Authorization for P. Kulzer \\
\hline 003 & 012589 & Harrison/Collentro & Lotter & $\begin{array}{l}\text { Comments Regarding Facllity } \\
\text { Enhancements at the Special Process } \\
\text { Laboratories, Ft. Meade, MD - Deionized- } \\
\text { Water Purification System }\end{array}$ \\
\hline 004 & 030189 & NSA File/Harrison & Memo & Signature Authorization for L. Narug. \\
\hline 005 & 032889 & $\begin{array}{l}\text { Harrison \& Stevens / } \\
\text { Engelkemeir }\end{array}$ & Memo & $\begin{array}{l}\text { Test Data for Residual Gases in High- } \\
\text { Purity Piping System, SPL, Fl. Mcade, } \\
\text { MD }\end{array}$ \\
\hline 006 & 041789 & File/Slack Associates & Report & $\begin{array}{l}\text { Preliminary Data From Slack Associales } \\
\text { on Leak Check of High-Purity-Gas Pipe } \\
\text { System }\end{array}$ \\
\hline 007 & 041789 & File/Rapa & Report & $\begin{array}{l}\text { NSA Special Processing Lab - Design } \\
\text { Comments }\end{array}$ \\
\hline 008 & 111090 & F le/Miller & Memo & "NSAIO-008" removed from lile \\
\hline 009 & $051289 / 052289$ & Book. & Submittal & $\begin{array}{l}\text { Temperature Control Submittal for Ft. } \\
\text { Meade }\end{array}$ \\
\hline 010 & 053189 & File/Harrison & Telecon Record & $\begin{array}{l}\text { Conversation between M. Musko \& L. } \\
\text { Soule on Persons Attending Weckly } \\
\text { Construction Mectings }\end{array}$ \\
\hline 011 & 060789 & $\begin{array}{l}\text { File/ANL-NSA } \\
\text { Personnel }\end{array}$ & Addendum & Addendum 1 to Package 5 \\
\hline 012 & 062089 & Harrison/Shepard & Fux & Arch./Structural Requirements \\
\hline 013 & 070789 & File/Harrison & Memo & $\begin{array}{l}\text { Mecting of July } 7,1989 \text {, between ANL': } \\
\text { W. Harrison, L. Shepard, M. Musto, and } \\
\text { N. Malik and NSA's D. Kokalis }\end{array}$ \\
\hline 014 & 072789 & Harrison/Collentro & Letter & $\begin{array}{l}\text { Specifications f'or Multi-Media Filters - } \\
\text { United States Department of Del'enses-Fort } \\
\text { George G. Meade, MD }\end{array}$ \\
\hline 015 & 072889 & File/Gerbig & Report & $\begin{array}{l}\text { Clean Room Construction at SPL, Fl. } \\
\text { Meade, Progress Review Trip }\end{array}$ \\
\hline 016 & 080289 & File & Minutes & $\begin{array}{l}\text { NSA/NSC Construction Mecting: } \\
\text { Date/Time: August 1, 1989 / 1:(0) pm } \\
\text { Place: NSA SPL Trailer, Fl, Mcalc, MD }\end{array}$ \\
\hline
\end{tabular}


INDEX FOR CORRESPONDENCE FILE 1.3.3 (NSAIO)

Documents Incoming to ANL from Other Than NSA

\begin{tabular}{|c|c|c|c|c|}
\hline NSAIO- & Dated/Rcvd & To/From & Description & Subject \\
\hline 017 & 080489 & Harrison/Collentro & Fax & $\begin{array}{l}\text { Specification For Enhancement to } \\
\text { Pretreatment Equipment At Special } \\
\text { Process Laboratory - Ft. Meade, MD }\end{array}$ \\
\hline 018 & 080489 & Harrison/Shepard & Memo & $\begin{array}{l}\text { Monthly Report For July 1989, SPL/NSA } \\
\text { Fort Meade, MD }\end{array}$ \\
\hline 019 & 081689 & Maley/Malik & Memo & $\mathrm{NaOH}$ Talık Leak T'est \\
\hline 020 & 081789 & Harrison/Shepard & Memo & $\begin{array}{l}\text { Specification Test Schedule and SPL } \\
\text { Construction Schedule }\end{array}$ \\
\hline 021 & 090889 & File & Minutes & $\begin{array}{l}\text { NSA/NSC Construction Meeting: } \\
\text { Date/Time: Scptember 5, 1989 / 1:00 pm } \\
\text { Place: NSA SPL Trailer, Ft. Meade, MD }\end{array}$ \\
\hline 022 & 091389 & File & Minutes & $\begin{array}{l}\text { NSA/NSC Construction Mecting: } \\
\text { Date/Time: Scptember 12, 1989/1:00 pm } \\
\text { Place: NSA SPL Trailer, Ft. Meade, MD }\end{array}$ \\
\hline 023 & 091489 & Hays/Cunningham & Letter & $\begin{array}{l}\text { Review of Proposed City Watcr Booster } \\
\text { System }\end{array}$ \\
\hline 024 & 092089 & File & Minutes & $\begin{array}{l}\text { NSA/NSC Construction Mecting: } \\
\text { Date/Time: September 19, 1989/1:00 pm } \\
\text { Place: NSA SPL Trailer, Ft. Mcade, MD }\end{array}$ \\
\hline 025 & 091989 & File & Minutes & Contractor Coordinator Mecting \\
\hline 026 & 092589 & File & Schedule & DI Water System Schedule \\
\hline 027 & 092589 & File & Schedule & SPL Facility and Equipment Schcdule \\
\hline 028 & 092789 & File & Minutes & $\begin{array}{l}\text { NSA/NSC Construction Meeting: } \\
\text { Date/Time: September 26, 1989/1:00 pmm } \\
\text { Place: NSA SPL Trailer, Ft. Mcadc, MD }\end{array}$ \\
\hline 029 & 040789 & Shepard & Memo & $\begin{array}{l}\text { LEPCO Ducument Revicw, SPL/NSA, } \\
\text { Ft. Meade, MD }\end{array}$ \\
\hline 030 & 061589 & Maley/Frederick & Enclosure & $\begin{array}{l}\text { First effort at producing a specilication for } \\
\text { the procurement of multi-medialilicrs for } \\
\text { addition to the SPL high-purity water- } \\
\text { treatment system } \\
\text { Procurement Specification / Multi-Media } \\
\text { Filter Addition }\end{array}$ \\
\hline 031 & $092689 / 120989$ & File & Minutes & $\begin{array}{l}\text { Contractor Coordinator Mecting } \\
26 \text { Septernber } 1989\end{array}$ \\
\hline 032 & 100289,120089 & File & Minutes & $\begin{array}{l}\text { Contractor Comrdinator Mecting } \\
2 \text { October } 1989\end{array}$ \\
\hline
\end{tabular}


INDEX FOR CORRESPONDENCE FILE 1.3.3 (NSAIO)

Documents Incoming to ANL from Other Than NSA

\begin{tabular}{|c|c|c|c|c|}
\hline NSAIO- & Dated/Rcvd & To/From & Description & Subject \\
\hline 033 & 120989 & File & Minutes & $\begin{array}{l}\text { NSA/NSC Construction Mceting: } \\
\text { Date/Time: October } 2,1989 \text { / 1:00 pm } \\
\text { Place: NSA SPL Trailer, Ft. Meade, MD }\end{array}$ \\
\hline 034 & $101689 / 120989$ & File & Minutes & $\begin{array}{l}\text { NSA/NSC Construction Mecting: } \\
\text { Date/Time: October 10, 1989/1:00 pm } \\
\text { Place: NSA SPL Trailer, Ft. Mcade, MD }\end{array}$ \\
\hline 035 & 120989 & File & Minutes & $\begin{array}{l}\text { NSA/NSC Construction Meeting: } \\
\text { Date/Time: October 17, } 1989 \text { / 1:00 pm } \\
\text { Place: NSA SPL Trailer, Ft. Mcadc, MD }\end{array}$ \\
\hline \multirow[t]{4}{*}{036} & 120989 & QA File/Harrison & Notes & $\begin{array}{l}101989 \text { Mecting with D. Kokalis / } \\
101989 \text { Mecting with L. Shepard, M. } \\
\text { Musko, and T. Cunningham }\end{array}$ \\
\hline & & & Enclosure & $\begin{array}{l}\text { SPL Transfer Statement of Work } \\
11 \text { January } 88\end{array}$ \\
\hline & & & Enclosure & $\begin{array}{l}\text { SPL } 1.2 \text { Micron Acquisition Design } \\
\text { Statement of Work, } 10 \text { June } 88\end{array}$ \\
\hline & & & Enclosure & $\begin{array}{l}\text { SPL Acquisition Purchase Description, } \\
4 \text { August } 1988\end{array}$ \\
\hline 037 & 120989 & File & Minutes & $\begin{array}{l}\text { NSA/NSC Construction Mccung: } \\
\text { Date/Time: October 24, } 1989 / 1: 00 \mathrm{pm} \\
\text { Place: NSA SPL Trailer, Ft. Mcadc, MD }\end{array}$ \\
\hline 038 & 120989 & File & Minutes & $\begin{array}{l}\text { NSA/NSC Construction Mecting: } \\
\text { Date/Time: October } 30,1989 / 1:(0) \text { pm } \\
\text { Place: NSA SPL Trailer, Fl. Meadc, MD }\end{array}$ \\
\hline 039 & 120989 & File & Minutes & $\begin{array}{l}\text { NSA/NSC Construction Mecting: } \\
\text { Date/Time: November 7, 1989/1:00 pm } \\
\text { Place: NSA SPL Trailer, Ft. Mcadc, MD }\end{array}$ \\
\hline 040 & 120989 & File & Point Paper & Walk through, 9 Nov. 89 \\
\hline 041 & 120989 & QA File/Harrison & Memo & $\begin{array}{l}\text { Meeting with R Group's David Kokalis of } \\
\text { November 16, } 1989\end{array}$ \\
\hline & & Kokalis/Shepard & $\begin{array}{l}\text { Memo } \\
\text { Attachment }\end{array}$ & $\begin{array}{l}\text { Deficiency List } 15 \text { Nov89 } \\
\text { Same as above }\end{array}$ \\
\hline 042 & $112789 / 120989$ & File & Minutes & $\begin{array}{l}\text { NSA/NSC Construction Mecting: } \\
\text { Date/Time: November } 21,1989 / 1:()() \text { pm } \\
\text { Place: NSA SPL Trailer, Fl. Meade, MD }\end{array}$ \\
\hline 043 & 121089 & File & Minutes & $\begin{array}{l}\text { NSA/NSC Construction Mecting: } \\
\text { Date/Time: November } 28,1989 / 1:()() \mathrm{pm} \\
\text { Place: NSA SPL Trailer, Ft. Meade, MD }\end{array}$ \\
\hline 044 & 121089 & File & Minutes & $\begin{array}{l}\text { NSA/NSC Construction Mecling: } \\
\text { Date/Time: December } 5,1989 / 1: 00 \mathrm{pm} \\
\text { Place: NSA SPL Trailer. Fl. Mealdc. MD }\end{array}$ \\
\hline
\end{tabular}


INDEX FOR CORRESPONDENCE FILE 1.3.4 (NSAIO"A")

Documents Incoming to ANL from Other Than NSA

\begin{tabular}{|c|c|c|c|c|}
\hline NSAIO- & Dated/Rcvd & To/From & Description & Subject \\
\hline 045 & $121189 / 011590$ & List/Nyman & Minutes & $\begin{array}{l}\text { Contractors Meeting Summary - } \\
6 \text { December } 1989\end{array}$ \\
\hline 046 & $011890 / 021290$ & Shepard/Smith & $\begin{array}{l}\text { Memo } \\
\text { Enclosure }\end{array}$ & $\begin{array}{l}\text { Sprinkler System Serving the SPL } \\
\text { Building } \\
\text { Outline of problem with the SPL sprinkler } \\
\text { system..."Main line water pressure has } \\
\text { dropped below value required to provide } \\
\text { adequate sprinkler coverage to the SPL } \\
\text { Facility. Argonne to review the situation } \\
\text { and recommend corrective action required." }\end{array}$ \\
\hline 047 & $051690 / 052990$ & Shepard/Cunningham & Fax Trans & $\begin{array}{l}\text { T. Cunningham's response to project } \\
\text { review comments made by Matt Walch } \\
\text { (L521) to Jerry Pogue } 5-14-90 \text { (attached) }\end{array}$ \\
\hline
\end{tabular}




\section{QA COMMUNICATIONS RECORD 1.3 .5 (NSAON) Documents Outgoing to NSA}

\begin{tabular}{|c|c|c|c|c|}
\hline NSAON- & Dated/Rcvd & To/From & Description & Subject \\
\hline \multirow[t]{5}{*}{001} & \multirow[t]{6}{*}{012589} & \multirow[t]{6}{*}{$\begin{array}{l}\text { Hoehn/Harrison/ } \\
\text { RWP }\end{array}$} & Letter & $\begin{array}{l}\text { Sense-of-the-Mecting Report for the Tiger } \\
\text { Team's Review of the SPL's Deionized- } \\
\text { Water System, January } 18 / 19,1989\end{array}$ \\
\hline & & & Attachment A & $\begin{array}{l}\text { ANL's Original Performance Review } \\
\text { Report on the Dejonized-Water and } \\
\text { Wastewater-Treatment Systems }\end{array}$ \\
\hline & & & Attachment B & $\begin{array}{l}\text { Process Flow Diagram of Enhancements } \\
\text { Agreed to by NSC, NSA and ANL }\end{array}$ \\
\hline & & & Attachment C & $\begin{array}{l}\text { Description of Enhancements Agrecd to by } \\
\text { NSC, NSA and ANL. }\end{array}$ \\
\hline & & & Attachment D & $\begin{array}{l}\text { ANL Commentary on Minimal } \\
\text { Enhancements Required to Produce } \\
\text { Semiconductor Grade Water and Expected } \\
\text { Performance of Proposed Enhancements }\end{array}$ \\
\hline & & & Enclosure & $\begin{array}{l}\text { System Performance Review of the } \\
\text { Deionized-Water and Wastewater- } \\
\text { Treatment Systems at the Special Process } \\
\text { Laboratorics, Fl. Meade, MD }\end{array}$ \\
\hline 002 & 020289 & Soule/Harrison & Letter & $\begin{array}{l}\text { NSA Area Office Concurrence with ANL's } \\
\text { Selection of Panelists for Performance } \\
\text { Reviews of Phase II Enhancements to the } \\
\text { Special Process Laboratorics Building }\end{array}$ \\
\hline \multirow[t]{2}{*}{003} & \multirow[t]{2}{*}{022389} & \multirow[t]{2}{*}{ Soule/Harrison } & Letter & $\begin{array}{l}\text { Argonne's Interim Review Report On } \\
\text { National Scmiconductor Corporation's } \\
\text { Enhancements to the Clcan Room } \\
\text { Systems at the Special Process } \\
\text { Laboratorics }\end{array}$ \\
\hline & & & Enclosure & $\begin{array}{l}\text { Internal Dociment / Intcrim Revicw of } \\
\text { National Semiconductor Corp's } \\
\text { Enhancements to the Clean Room System } \\
\text { at SPL, Ft. Meade }\end{array}$ \\
\hline \multirow[t]{2}{*}{004} & \multirow[t]{2}{*}{061689} & \multirow[t]{2}{*}{ Kokalis/Harrison } & Letter & $\begin{array}{l}\text { Informal Review of NSC's "Package 5" } \\
\text { Spec }\end{array}$ \\
\hline & & & Attachment & $\begin{array}{l}\text { Informal Review of NSC's Package } 5 \\
\text { "Environmental Protection Systems" }\end{array}$ \\
\hline 005 & 070789 & Kokalis/Shepard & Memo & $\begin{array}{l}\text { Job Status, SPL/NSA, Ft. Meade, MD: } \\
\text { Deficiencics in the construction of the } \\
\text { second phase for Area } \mathrm{E}\end{array}$ \\
\hline 006 & 070789 & Soule/Shepard & Memo & $\begin{array}{l}\text { Marshall Group Schcdule } \\
\text { Dated May } 30,1989 \text { NSA/R } 105, \\
\text { SPL/NSA Ft. Mcade, MD: } \\
\text { Progress of Marshall Group's portion of } \\
\text { SPL construction }\end{array}$ \\
\hline
\end{tabular}


QA COMMUNICATIONS RECORD 1.3.5 (NSAON)

Documents Outgoing to NSA

\begin{tabular}{|c|c|c|c|c|}
\hline NSAON- & Dated/Revd & To/From & Description & Subject \\
\hline 007 & 071789 & Kokalis/Harrison & Altachment & $\begin{array}{l}\text { Final Version of ANL's Informal Review } \\
\text { of National Semiconductor Corporation's } \\
\text { Package } 5 \text { "Environmental Protection } \\
\text { Systems" } \\
\text { Same as above }\end{array}$ \\
\hline 008 & 072189 & Kokalis/Shepard & Memo & $\begin{array}{l}\text { Hydrogen, Nitrogen and Oxygen, } \\
\text { Concrete/Masonry Work, SPL/NSA } \\
\text { FL. Meade, MD }\end{array}$ \\
\hline 009 & 072689 & QA File/Harrison & Memo & Signature Authority for Diana Gierich \\
\hline 010 & 073189 & Kokalis/Harrison & $\begin{array}{l}\text { Letter } \\
\text { Altachment }\end{array}$ & $\begin{array}{l}\text { Informal Argonne Review of Clcan Room } \\
\text { Construction at the SPL, July 20, } 1989 \\
\text { Clean Room Construction at SPL, } \\
\text { Progress Review Trip, Gerbig }\end{array}$ \\
\hline 011 & 073189 & Kokalis/Harrison & $\begin{array}{l}\text { Letuer } \\
\text { Altachment }\end{array}$ & $\begin{array}{l}\text { Informal Review of ION Exchange } \\
\text { Associates, Inc., Specifications for Multi- } \\
\text { Media Filters } \\
\text { Technical Review of Specifications for } \\
\text { Multimedia Filters for the SPL Building's } \\
\text { Deionized-Water System }\end{array}$ \\
\hline 012 & 080289 & Kokalis/Shepard & $\begin{array}{l}\text { Memo } \\
\text { Specifications }\end{array}$ & $\begin{array}{l}\text { Integrated Cleanroom Systems Protocol } \\
\text { Review, SPLNSA Ft. Meade, MD } \\
\text { Section 13040. Integrated Clean Room } \\
\text { Systems }\end{array}$ \\
\hline 013 & 080389 & Kokalis/Harrison & $\begin{array}{l}\text { Letter } \\
\text { Enclosure }\end{array}$ & $\begin{array}{l}\text { ANL's Specifications for a Multimedia } \\
\text { Prefilter Subsystem for the SPL's } \\
\text { Deionized-Water System } \\
\text { Specifications for Enhancements } \\
\text { Equipment at the SPL, Ft. Meade, MD }\end{array}$ \\
\hline 014 & $08038 !$ & Kokalis/Shepard & Memo & $\begin{array}{l}\text { Owner-Supplied Equipment for MEBES } \\
\text { Area (LEPCO Work Area) SPL/NSA FI. } \\
\text { Meade, MD }\end{array}$ \\
\hline 015 & 080789 & Kokalis/Harrison & Letter & $\begin{array}{l}\text { Summary Report for Work Conducted by } \\
\text { ANL During July, } 1989\end{array}$ \\
\hline 016 & 080789 & Kokalis/Shepard & $\begin{array}{l}\text { Memo } \\
\text { Attachment }\end{array}$ & $\begin{array}{l}\text { Preliminary Punch List For LEPCO, } \\
\text { SPL/NSA Ft. Mcade, MD } \\
\text { Same as above }\end{array}$ \\
\hline 017 & 081089 & Kokalis/Shepard & $\begin{array}{l}\text { Memo } \\
\text { Aluachment }\end{array}$ & $\begin{array}{l}\text { Specification Test Schedulc } \\
\text { SPL/NSA Ft. Mcade, MD } \\
\text { Test Requirements for SPL Enhancements }\end{array}$ \\
\hline 018 & 081089 & Kokalis/Shepard & Memo & $\begin{array}{l}\text { Painting Requircments for SPL } \\
\text { Enhancements, SPL/NSA } \mathrm{Ft} \text {. Meade, } \\
\text { MD }\end{array}$ \\
\hline
\end{tabular}


QA COMMUNICATIONS RECORD 1.3.5 (NSAON)

Documents Outgoing to NSA

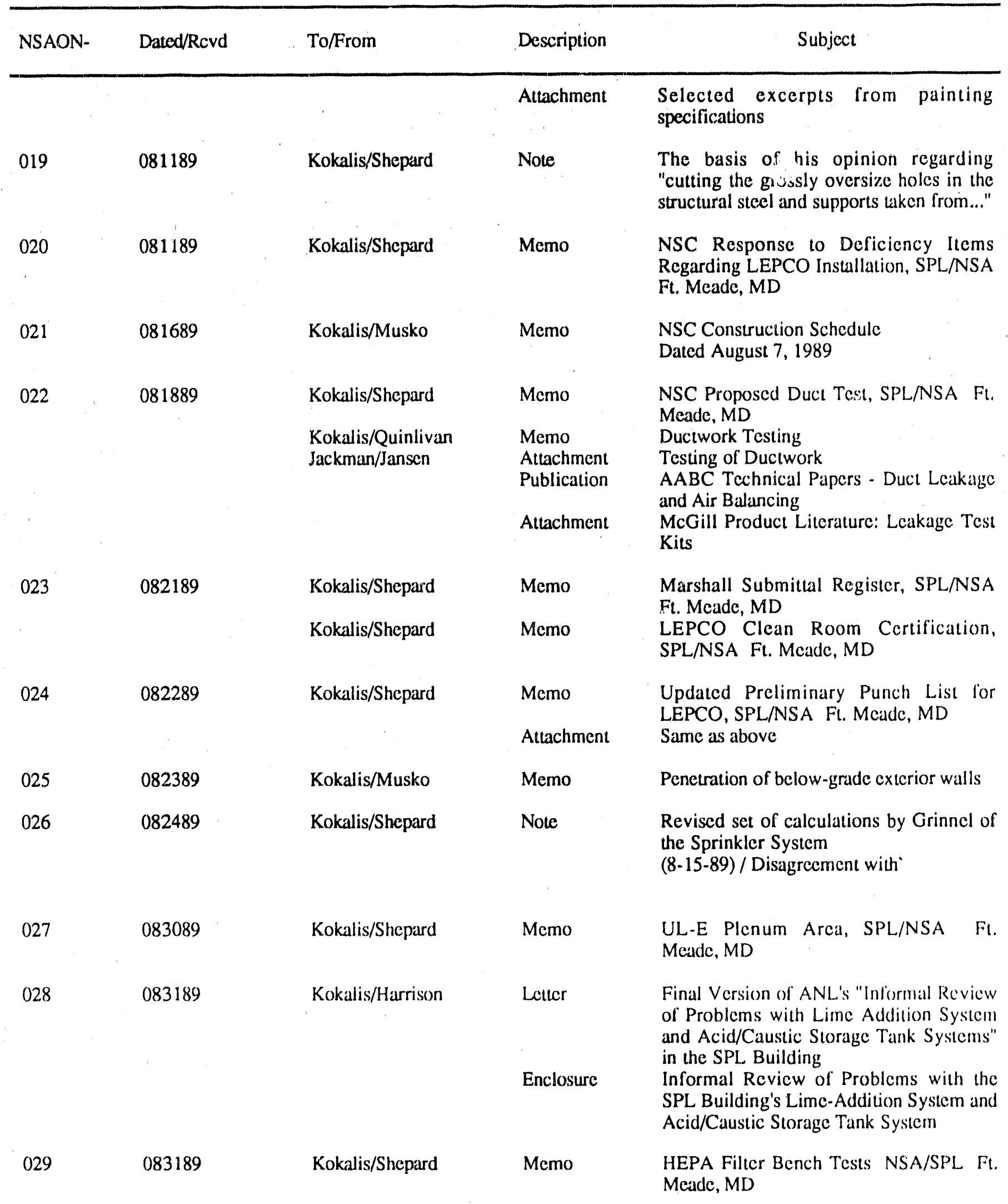




\section{QA COMMUNICATIONS RECORD 1.3.5 (NSAON) \\ Documents Outgoing to NSA}

\begin{tabular}{|c|c|c|c|c|}
\hline NSAON- & Dated/Rcvd & To/From & Description & Subject \\
\hline 030 & 090589 & Kokalis/Shepard & $\begin{array}{l}\text { Memo } \\
\text { Specification }\end{array}$ & $\begin{array}{l}\text { Clean Room Certification, NSA/SPL Ft. } \\
\text { Meade, MD } \\
\text { Section } 15050 \text { Clean Room Construction }\end{array}$ \\
\hline 031 & 090689 & Kokalis/Musko & Memo & $\begin{array}{l}\text { Interrupting Rating of Circuit Breakers } \\
\text { (Item 201) }\end{array}$ \\
\hline 032 & 090789 & Kokalis/Shepard & Memo & $\begin{array}{l}\text { Clean Room Corridors, } \\
\text { NSA/SPL Ft. Meade, MD }\end{array}$ \\
\hline 033 & 091189 & Kokalis/Shepard & Memo & $\begin{array}{l}\text { High Pressure Duct Testing, SPL/NSA } \\
\text { Ft. Meade, MD }\end{array}$ \\
\hline 034 & 091889 & Kokalis/Shepard & Memo & $\begin{array}{l}\text { Punchlist for Area A, North End, Floor to } \\
\text { Ceiling and Chases }\end{array}$ \\
\hline 035 & 092089 & Kokalis/Shepard & Memo & Balance and Certification of Cleanrooms \\
\hline 036 & 092189 & Kokalis/Shepard & Note & $\begin{array}{l}\text { Manufacturers Recommendation on } \\
\text { Mipolan Floor Cleaning }\end{array}$ \\
\hline 037 & $100589 / 120989$ & Kokalis/Cunningham & Letter & $\begin{array}{l}\text { Inspection, Examination, Testing and } \\
\text { Certification of High-Purity Piping } \\
\text { Systems (Dated 5Oct89) }\end{array}$ \\
\hline 038 & $101689 / 120989$ & Kokalis/Cunningham & Letter & $\begin{array}{l}\text { Mecting of Oct. } 11 \text { to discuss D. I. Watcr } \\
\text { System Filtration (Dated 11Oct89, Revd } \\
\text { 101689) }\end{array}$ \\
\hline 039 & $101789 / 120989$ & Kokalis/Cunningham & $\begin{array}{l}\text { Letter } \\
\text { Enclosure }\end{array}$ & $\begin{array}{l}\text { Leak Testing Procedure for Inert Gas and } \\
\text { Coaxial Tubing (Dated 170ct89) } \\
\text { Leak Testing Procedure }\end{array}$ \\
\hline 040 & $101789 / 120989$ & Kokalis/Cunningham & Letter & $\begin{array}{l}\text { Testing of High-Purity Piping Systems } \\
\text { (Dated 170c189) }\end{array}$ \\
\hline 041 & $102689 / 120989$ & Kokalis/Shepard & Memo & $\begin{array}{l}\text { High Purity Pipe Test Report for Existing } \\
\text { Piping (Dated } 260 \mathrm{ct} 89 \text { ) }\end{array}$ \\
\hline 042 & $101889 / 120989$ & Kokalis/Cunningham & Letter & $\begin{array}{l}\text { Testing of Special Gas Distribution } \\
\text { System (dated } 180 \mathrm{ct} 89 \text { ) }\end{array}$ \\
\hline 043 & $101789 / 120989$ & Kokalis/Cunningham & Letter & $\begin{array}{l}\text { Installation of Ulurafilter and Mixed Beds } \\
\text { (Dated 170et89) }\end{array}$ \\
\hline 044 & 120989 & Kokalis/Cunningham & Letter & Sprinkler Calculations (Dated 310ct89) \\
\hline
\end{tabular}

Closed February 1990. Con inustion in NSAON Log"A" 


\section{INDEX FOR CORRESPONDENCE FILE 1.3.6 (NSAON"A") Documents Outgoing to NSA from ANL}

\begin{tabular}{|c|c|c|c|c|}
\hline NSAON- & Dated/Rcvd & To/From & Description & Subject \\
\hline 045 & 010390 & Kokalis/Shepard & Memo & $\begin{array}{l}\text { A,C,D Walk-Through 27Nov89, } \\
\text { Dated 08Dec89 }\end{array}$ \\
\hline \multirow[t]{11}{*}{046} & 010390 & Kokalis/Shepard & Memo & $\begin{array}{l}\text { AHU-9C (A,C,D Contract), Dated } \\
11 \text { Dec } 89\end{array}$ \\
\hline & & Naylor/Ryals & Attachment & $\begin{array}{l}\text { (15805,15835) AHU-9C Return Air } \\
\text { Plenum (Dated 07Mar88) }\end{array}$ \\
\hline & & Warren/Ryals & Attachment & $\begin{array}{l}\text { Request for proposal (15805,15835) } \\
\text { AHU-9C Return Air Plenum (Dated } \\
\text { 08Mar88) }\end{array}$ \\
\hline & & Naylor/Ryals & Attachment & $\begin{array}{l}\text { Return Air System for AHU-9C } \\
\text { (Dated 05Feb88) Change Order Price } \\
\text { Pr }\end{array}$ \\
\hline & & $\begin{array}{l}\text { Warren } \\
\text { Warren/Maiolo }\end{array}$ & $\begin{array}{l}\text { Attachment } \\
\text { Attachment }\end{array}$ & $\begin{array}{l}\text { Change Order } 136 \text { Price Proposal } \\
\text { JJ Kilin Change Proposal \#116 } \\
\text { Date 5/9/88 COE Change \#P/P136 }\end{array}$ \\
\hline & & /Maiolo & Attachment & $\begin{array}{l}\text { JJK Project \#476, Change Proposal } \\
\# 116 \text { COE Change \#P/P136 }\end{array}$ \\
\hline & & Maiolo/Gawne & Attachment & $\begin{array}{l}\text { AHU-9C C.O, \#136 Rev. No. } 1 \\
\text { (Dated May 5, 1988) }\end{array}$ \\
\hline & & Warren/Riechers & $\begin{array}{l}\text { Attachment } \\
\text { Attachment }\end{array}$ & $\begin{array}{l}\text { C.O. \#136 AHU } 9 \mathrm{C} \\
\text { Change Order Summary C. O. } \# 136 \\
\text { AHU } 9 \text { C (Dated } 4 / 12 / 88)\end{array}$ \\
\hline & & Maiolo/Warren & Attachment & $\begin{array}{l}\text { Request for Proposal Change Order } \\
\# 136 \text { Rev. } \# 1\end{array}$ \\
\hline & & Warren/Shulas & $\begin{array}{l}\text { Altachment } \\
\text { Altachment }\end{array}$ & $\begin{array}{l}\text { C. O. } 136 \mathrm{P} / \mathrm{P} \text { Price } \\
\text { Enginecring and Re-Production Cost } \\
\text { Estimate Summary (Dated } 5 / 12 / 88 \text { ) }\end{array}$ \\
\hline & & & Altachment & Floor Plans for Arcas C \& D \\
\hline 047 & 121189 & Kokalis/Shepard & Note & $\begin{array}{l}\text { Please write Wyman an authorization } \\
\text { note for an informal review of the fire- } \\
\text { protection systems per our discussion. }\end{array}$ \\
\hline 048 & $121889 / 010390$ & $\begin{array}{l}\text { Kokalis/ } \\
\text { Cunningham }\end{array}$ & Letter & $\begin{array}{l}\text { Sprinkier System Informal Review } \\
\text { For SPL Facility (Dated 18DEC89) }\end{array}$ \\
\hline \multirow[t]{3}{*}{049} & 012290 & Shepard/Kokalis & Memo & $\begin{array}{l}\text { NSC Contractors Mecting Summary, } \\
\text { Dated 11Dec89 }\end{array}$ \\
\hline & & List/Nyman & Attachment & $\begin{array}{l}\text { Contractors Mecting Summary } \\
\text { December 6, } 1989 \text { (Dated December } \\
11,1989 \text { ) }\end{array}$ \\
\hline & & Kokalis/Lewis & Note & $\begin{array}{l}\text { Allach d you will find... (Dalted 10)- } \\
25-89)\end{array}$ \\
\hline 050 & $013190 / 020190$ & Kokalis/Shcpard & Memo & Safety Alarms Mecting $31 \operatorname{Jan} 9()$ \\
\hline 051 & $\begin{array}{l}013190 /(21290 \\
081089\end{array}$ & $\begin{array}{l}\text { Kokalis/Shcpard } \\
\text { Kokalis/Shepard }\end{array}$ & $\begin{array}{l}\text { Memo } \\
\text { Altchd Memo } \\
\text { Attachment }\end{array}$ & $\begin{array}{l}\text { Safety/Alarms Mecting } 31 \text { Jang() } \\
\text { Specification Test Schedulc } \\
\text { Same as above }\end{array}$ \\
\hline
\end{tabular}


INDEX FOR CORRESPONDENCE FILE 1.3.6 (NSAON"A")

Documents Outgoing to NSA from ANL

\begin{tabular}{|c|c|c|c|c|}
\hline NSAON- & Dated/Rcvd & To/From & Description & Subject \\
\hline & 051789 & Soule/Shepard & Attchd Merno & $\begin{array}{l}\text { Contractor Quality Control } \\
\text { NSA/R } 108 \text { SPL, Ft. Meade, MD } \\
\text { w/Section 01400 CQC Attached }\end{array}$ \\
\hline 052 & $020790 / 021290$ & Kokalis/Musko & Letter & $\begin{array}{l}\text { SPL Wing E Fire-Prolcction } \\
\text { Preliminary Testing Reference: } \\
\text { Memo from K. Wade to C. Lewis } \\
\text { dated 6Feb90 (same subject as above) }\end{array}$ \\
\hline 053 & $020990 / 021290$ & Kokalis/Shepard & Memo & $\begin{array}{l}\text { Contractor Quality Control, Existing } \\
\text { Sprinkler System in UL.E }\end{array}$ \\
\hline 054 & 022090 & Kokalis/Cunningham & Letter & $\begin{array}{l}\text { Lower Level E Fire Protection } \\
\text { System }\end{array}$ \\
\hline 055 & $041390 / 041690$ & Kokalis/Musko & Memo & SPL Sprinkler System Analysis \\
\hline 056 & $051890 / 052190$ & Kokalis/Shepard & Memo & $\begin{array}{l}\text { Response to LS2 Comments } \\
\text { Regarding ANL/SPL Sprinkler } \\
\text { Systems Review }\end{array}$ \\
\hline 057 & $060790 / 062690$ & Kokalis/Shepard & Memo & $\begin{array}{l}\text { UL-E Sprinkler Shop Drawing } \\
\text { Review }\end{array}$ \\
\hline 058 & $062790 / 071690$ & Kokalis/McFadden & Letter & $\begin{array}{l}\text { Preliminary Current Total Cooling } \\
\text { Loads For Chilled Water System } \\
\left(42^{\circ} \mathrm{F} \text { Water) and Process Chilled }\right. \\
\text { Water System ( } 39^{\circ} \mathrm{F}-20 \% \\
\text { GlycolWater) }\end{array}$ \\
\hline 059 & $070490 / 071690$ & Kokalis/Shepard & Memo & UL-E Sprinkler Review \\
\hline 060 & $070990 / 071690$ & Kokalis/Shepard & Memo & NSA/NSC PSR Mecting 28Jun 90 \\
\hline 061 & $072490 / 082390$ & Kokalis/McFadden & Letter & Sequencing of Chillers \\
\hline 062 & $080290 / 082390$ & Kokalis/McFadden & Letter & $\begin{array}{l}\text { Chilled Water System-Lowering of } \\
\text { Chilled Water Temperature }\end{array}$ \\
\hline 063 & 091190 & $\begin{array}{l}\text { Bradford- } \\
\text { Kokalis/Harrison }\end{array}$ & Fax trans & $\begin{array}{l}\text { 'Attached as per conversation this } \\
\text { morning'..."Argonne will conduct the } \\
\text { following activities during the close- } \\
\text { out period between Oct. } 1 \text { and Dec. } \\
31,1990 "\end{array}$ \\
\hline 064 & 121490 & Kokalis/Shepard & Memo & $\begin{array}{l}\text { Transmittal of Argonne National } \\
\text { Laboratory Final Report, "Final } \\
\text { Construction-Monitoring Report For } \\
\text { The Phase-II Enhancements To E- } \\
\text { Area. Special Process Laboratories" }\end{array}$ \\
\hline
\end{tabular}


INDEX FOR CORRESPONDENCE FILE 1.3.7 (NSAOO) Documents Outgoing to Other Than NSA

\begin{tabular}{|c|c|c|c|c|}
\hline NSAOO. & Dated/Rcvd & To/From & Description & Subject \\
\hline 001 & 013089 & Stevens/Harrison & Memo & $\begin{array}{l}\text { Session Chairmanship for Performance } \\
\text { Review of National Semiconductor's } \\
\text { (NSC) Proposed Enhancements to the } \\
\text { Clean Room Systems Located in the NSA } \\
\text { Building Ft. Meade, MD }\end{array}$ \\
\hline 002 & 013089 & Peters/Harrison & Memo & $\begin{array}{l}\text { Session Chairmanship for Performance } \\
\text { Review of National Semiconductor's } \\
\text { (NSC) Proposed Enhancements to the } \\
\text { Deionization-Water System Lecated in the } \\
\text { NSA Building Ft. Meade, MD }\end{array}$ \\
\hline 003 & 013189 & Stevens/Harrison & Memo & $\begin{array}{l}\text { Request for Technical Review of National } \\
\text { Semiconductor's Enhancements to the } \\
\text { Clean Room Systems at the National } \\
\text { Security Agency's (NSA's) Special } \\
\text { Process Laboratories, Fl. Meade, MD }\end{array}$ \\
\hline \multirow[t]{4}{*}{004} & \multirow[t]{4}{*}{020689} & \multirow[t]{4}{*}{ Gerbig/Stevens } & Memo & $\begin{array}{l}\text { Specifications and layout drawings for } \\
\text { NSC's proposed clean room system } \\
\text { enhancements }\end{array}$ \\
\hline & & & Enclosure & Same as above \\
\hline & & & Enclosure & $\begin{array}{l}\text { Construction Specifications NSC/SPL Ft. } \\
\text { Meade, MD Facility Enhancements } \\
\text { Package } 2 \text { - Enhancements }\end{array}$ \\
\hline & & & Enclosure & $\begin{array}{l}\text { Performance Review of the Clean Room } \\
\text { Systems at the SPL Building, Fl. Meade, } \\
\text { MD }\end{array}$ \\
\hline 005 & 020689 & Malik/Stevens & Memo & $\begin{array}{l}\text { Information Packet for Performance } \\
\text { Review of NSC Proposed Enhancements } \\
\text { to the Clean Room Systems Localed in } \\
\text { the NSA Building. Ft. Meade, MD }\end{array}$ \\
\hline 006 & 020689 & Naegele/Stevens & Letter & $\begin{array}{l}\text { Specification and layout drawings for } \\
\text { NSC's proposed clean room systems } \\
\text { enhancements }\end{array}$ \\
\hline 007 & 020689 & Rapa/Stevens & Letter & $\begin{array}{l}\text { Specification and layout drawings for } \\
\text { NSC's proposed clean room systems } \\
\text { cnhancement }\end{array}$ \\
\hline 008 & 020989 & Stevens/Harrison & Memo & $\begin{array}{l}\text { Request for Technical Review of National } \\
\text { Semiconductor's (NSC) Enhancenents to } \\
\text { the Clean Room Systems at the Special } \\
\text { Process Laboratories Building, Ft. Meade, } \\
\text { MD }\end{array}$ \\
\hline
\end{tabular}


INDEX FOR CORRESPONDENCE FILE 1.3.7 (NSAOO)

Documents Outgoing to Other Than NSA

\begin{tabular}{|c|c|c|c|c|}
\hline NSAOO- & Dated/Revd & To/From & Description & Subject \\
\hline 009 & 020989 & Harrison/Harrison & Memo & $\begin{array}{l}\text { Request for Technical Review of National } \\
\text { Semiconductor's (NSC) Enhancements to } \\
\text { the Clean Room Systems at the Special } \\
\text { Process Laboratories Building. Fl. Meade, } \\
\text { MD }\end{array}$ \\
\hline 010 & 020989 & Gerbig/Harrison & Letter & $\begin{array}{l}\text { Request for Technical Review of National } \\
\text { Semiconductor's (NSC) Enhancements to } \\
\text { the Clean Room Systems at the Special } \\
\text { Process Laboratories Building, Fl. Meade, } \\
\text { MD }\end{array}$ \\
\hline 011 & 020989 & Rapa/Harrison & Leller & $\begin{array}{l}\text { Request for Technical Revicw of National } \\
\text { Semiconductor's (NSC) Enhancements to } \\
\text { the Clean Room Systems at the Special } \\
\text { Process Laboratories Bullding, Ft. Meade, } \\
\text { MD }\end{array}$ \\
\hline 012 & 020989 & Naegele/Harrison & Letter & $\begin{array}{l}\text { Request for Technical Review of National } \\
\text { Semiconductor's (NSC) Enhancements to } \\
\text { the Clean Roorn Systems at the Special } \\
\text { Process Laboratories Building, Fl. Meade, } \\
\text { MD }\end{array}$ \\
\hline 013 & 020989 & Collentro/Harrison & Letter & $\begin{array}{l}\text { Request for Performance Review of } \\
\text { National Semiconductor's Enhancement to } \\
\text { the Deionized-Water Sy'stem at the } \\
\text { National Security Agency's (NSA's) } \\
\text { Special Process Laboratories, Fl. Meade, } \\
\text { MD }\end{array}$ \\
\hline 014 & 020989 & Harrison/Harrison & Memo & $\begin{array}{l}\text { Request for Performance Review of } \\
\text { National Scmiconciuctor's Enhancement to } \\
\text { the Deionized-Water System at the } \\
\text { National Security Agency's (NSA's) } \\
\text { Special Process Laboratories, Fl. Meade, } \\
\text { MD }\end{array}$ \\
\hline 015 & 020989 & Peters/Harrison & Letter & $\begin{array}{l}\text { Request for Performance Revicw of } \\
\text { National Semiconductor's Enhancement to } \\
\text { the Deionized-Water System at the } \\
\text { National Security Agency's (NSA's) } \\
\text { Special Process Laboratories, Ft. Meade, } \\
\text { MD }\end{array}$ \\
\hline 016 & 020989 & Malik/Harrison & Merno & $\begin{array}{l}\text { Request for Technical Review of National } \\
\text { Semiconductor's (NSC) Enhancements to } \\
\text { the Cleanroom System at the Special } \\
\text { Process Laboratories Building, Ft. Meade, } \\
\text { MD }\end{array}$ \\
\hline 017 & 072689 & QA Filc/Harrison & Mcmo & Termination of "Panclists Filing System" \\
\hline
\end{tabular}


$41 / 42$

INDEX FOR CORRESPONDENCE FILE; 1.3 .7 (NSAOO)

Documents Outgoing to Other Than NSA

\begin{tabular}{|c|c|c|c|c|}
\hline NSADO- & Dated/Rcvd & To/From & Description & Subject \\
\hline 018 & 080989 & Peters/Harrison & Me', 10 & $\begin{array}{l}\text { Informal Review of Problems with Lime- } \\
\text { Addition System (and ANL's } \\
\text { Recommendations for Problem Solutions) } \\
\text { for the Wastewater"Treatment System, } \\
\text { SPL Building, Ft. Meade, MD }\end{array}$ \\
\hline
\end{tabular}

Closed February 1990. Continuation in NSAOO LOg"A" 


\section{INDEX FOR CORRESPONDENCE FILE 1.3.8 (NSAOO"A")}

Documents Outgoing to Other Than NSA

\begin{tabular}{|c|c|c|c|c|}
\hline NSAOO- & Dated/Rcvd & To/From & Description & Subject \\
\hline 019 & $121489 / 010390$ & File/Musko & Minutes & $\begin{array}{l}\text { Minutes of NSA/NSC SPL Construction } \\
\text { Meeting } \\
\text { Date/Time: December 12, } 1989 / 1: 00 \\
\text { pm } \\
\text { Place: NSA SPL Trailer } \\
\text { Fl. Meade, MD }\end{array}$ \\
\hline 020 & 010290 & File/Hurrison & $\begin{array}{l}\text { Memo } \\
\text { Attachment }\end{array}$ & $\begin{array}{l}\text { Photographs of Deliciencies In } \\
\text { Construction In Clcan Room Arcus } \\
\text { Same as above }\end{array}$ \\
\hline 021 & $122189 / 011590$ & File/Musko & Minutes & $\begin{array}{l}\text { Minutes of NSA/NSC SPL Construction } \\
\text { Meeting } \\
\text { Date/Time: December 19, } 1989 / 1:(0) \\
\text { pm } \\
\text { Place: NSA SPL Trailer } \\
\text { Ft. Meade, MD }\end{array}$ \\
\hline 022 & $121889 / 012290$ & File/Musko & Minutes & $\begin{array}{l}\text { Minutes of NSA/NSC SPL Construction } \\
\text { Mecting } \\
\text { Date/Time: January } 16,199(0 / 1:(0) \text { pm } \\
\text { Place: NSA SPL. Trailer } \\
\text { Ft. Meade, MD }\end{array}$ \\
\hline 023 & $011890 / 012290$ & $\begin{array}{l}\text { Rosenhan/ } \\
\text { Cunningham }\end{array}$ & Letter & $\begin{array}{l}\text { Please find enclosed the original disks for } \\
M^{\wedge} 2 \text { programs HP4M and HP6M... }\end{array}$ \\
\hline 024 & $011890 / 021290$ & File/Musko & Minutes & $\begin{array}{l}\text { Minutes of NSA/NSC SPL Construction } \\
\text { Meeting } \\
\text { Date/Time: January } 16,199(0) / 1:()() \mathrm{pm} \\
\text { Place: NSA SPL Trailer } \\
\text { Ft. Meade, MD }\end{array}$ \\
\hline 025 & $012690 / 021290$ & File/Musko & Minutes & $\begin{array}{l}\text { Minutes of NSA/NSC Mecting on } \\
\text { Declassification of LL-E } \\
\text { Date/Time: January } 25,199(1) / 1:(0) \text { pm } \\
\text { Place: NSC Office / } 1(0810 \text { Annapolis } \\
\text { Junction, Columbia, MD }\end{array}$ \\
\hline 026 & $020290 / 021290$ & Filc/Musko & Minutes & $\begin{array}{l}\text { Minutes of NSA/NSC SPL Construction } \\
\text { Mecting } \\
\text { Date/Time: January } 30,199() / 1:()() \mathrm{pm} \\
\text { Place: NSA SPL Trailer } \\
\text { Fl. Meade, MD }\end{array}$ \\
\hline 027 & $020890 /(21290$ & File/Musko & Minutes & $\begin{array}{l}\text { Minutes of NSA/NSC SPL Construction } \\
\text { Mecting } \\
\text { Date/Time: February } 6,199() / 1:(0) \text { pm } \\
\text { Place: NSA SPL Trailer } \\
\text { Ft. Meade, MD }\end{array}$ \\
\hline
\end{tabular}




\section{INDEX FOR CORRESPONDENCE FILE 1.3.8 (NSAOO"A") \\ Documents Outgoing to Other Tinan NSA}

\begin{tabular}{|c|c|c|c|c|}
\hline NSAOO- & Dated/Rcvd & To/From & Description & Subject \\
\hline 028 & 021690 & $\begin{array}{l}\text { Curningham/ } \\
\text { Rosenhan }\end{array}$ & Letter & $\begin{array}{l}\text { Fire flow calculations for NSA/SPL } \\
\text { building }\end{array}$ \\
\hline 029 & $033090 / 040490$ & $\begin{array}{l}\text { Harrison/ } \\
\text { Rosenhan }\end{array}$ & Lettor & $\begin{array}{l}\text { NSA.SPL Sprinkler System Anulysis } \\
\text { and Modifications }\end{array}$ \\
\hline 030 & $033090 / 041690$ & $\begin{array}{l}\text { Harrison/ } \\
\text { Roscrithan }\end{array}$ & $\begin{array}{l}\text { Letter } \\
\text { Altachments }\end{array}$ & $\begin{array}{l}\text { NSA/SPL Sprinklor System Analysis } \\
\text { and Modifications } \\
\text { Schematics, calculations, and narrative } \\
\text { material relating to the analysis and } \\
\text { proposed modifications to the NSA-SPL } \\
\text { building sprinklor system }\end{array}$ \\
\hline 031 & 091190 & Combs/Harrison & Memo & $\begin{array}{l}\text { Revised Closcoul Schedule and Budget } \\
\text { For Work Conducted Under Proposal P. } \\
89033 \text {. "Performance Assessment of } \\
\text { Systems to Support Semiconductor } \\
\text { Manufacturing for the National Security } \\
\text { Agency." Budget Estimate altached. }\end{array}$ \\
\hline
\end{tabular}




\section{$45 / 46$}

1.4 Index of Documents Pertaining to NSA-Sponsored Formal Reviews 
INDEX FOR CORRESPONDENCE FILE 1.4.1 (RNSAIN-OM)

Documents Incoming to ANL from NSA

\begin{tabular}{lllll}
\hline RNSAIN- & Dated/Rcvd & To/From & Description & Subject \\
\hline OM1 & $011290 / 011490$ & Harrison/Kokalis & Letter & $\begin{array}{l}\text { Request For Review of NSA's Opcrations } \\
\text { and Maintenance Concept for the SPL } \\
\text { Building }\end{array}$ \\
OM2 & $032390 / 040490$ & Harrison/Kokalis & Memo & $\begin{array}{l}\text { Request for Final Draft of SPL O\&M } \\
\text { Review Report }\end{array}$
\end{tabular}


INDEX FOR CORRESPONDENCE FILE 1.4.2 (RNSAIO-OM) Documents Incoming to ANL from Other Than NSA

\begin{tabular}{lllll}
\hline RNSAIO- & Dated/Rcvd & To/From & Description & Subject \\
\hline OM1 & 033090 & Jones/Hartison & Concurrence & $\begin{array}{l}\text { Concurrence Review of ANL's Draft } \\
\text { Review Report on NSA's Opcrations and } \\
\text { Maintenance Concepts for the SPL Building } \\
\text { (Handwritten suggestion) }\end{array}$
\end{tabular}


INDEX FOR CORRESPONDENCE FILE 1.4.3 (RNSAON-OM)

Documents Outgoing to NSA

\begin{tabular}{lllll}
\hline RNSAON- & Dated/Rcvd & To/From & Description & \multicolumn{1}{c}{ Subject } \\
\hline OM1 & 031290 & Kokalis/Harrison & Letter & $\begin{array}{l}\text { Agency Manager's Review of Argonne's Draft } \\
\text { Review Report on NSA's Operations and } \\
\text { Maintenance Concepts for the SPL Building }\end{array}$ \\
OM2 & 031290 & File/Harrison & Draft Copy & $\begin{array}{l}\text { Review of NSA's Operations and Maintcriance } \\
\text { Concepts for the Spccial Process Laboratorics } \\
\text { Building, Ft. Meade, Maryland }\end{array}$ \\
OM3 & Kokalis/Harrison & Letter & $\begin{array}{l}\text { Final Version of the ANL Revicw Report on } \\
\text { NSA's Opcrations And Maintenance Concepts } \\
\text { for the SPL Building } \\
\text { same as above }\end{array}$
\end{tabular}


INDEX FOR CORRESPONDENCE FILE 1.4.4 (RNSAOO-OM)

Documents Outgoing to Other Than NSA

\begin{tabular}{|c|c|c|c|c|}
\hline RNSAOO- & Dated/Rcvd & To/From & Description & Subject \\
\hline OM1 & $011890 / 011890$ & Stevens/Harrison & Attachments & $\begin{array}{l}\text { Your Designation As Review Session } \\
\text { Chairman for the ANL-Conducted Peer } \\
\text { Review of NSA's Operations and } \\
\text { Maintenance Concept for the SPO } \\
\text { Building } \\
\text { Beneficial Occupancy Date, Fit-Up } \\
\text { Contracting, 100\% Government } \\
\text { Operation, Proposed Resources, Proposed } \\
\text { Organizational Structure }\end{array}$ \\
\hline \multirow[t]{4}{*}{ OM2 } & 012990 & File/Harrison & Memo & $\begin{array}{l}\text { Scoping the Review of the Operations and } \\
\text { Maintenance Concept for the SPL } \\
\text { Building }\end{array}$ \\
\hline & $011290 / 011490$ & Harrison/Kokalis & Attachment & $\begin{array}{l}\text { Request for Review of NSA's Operations } \\
\text { and Maintenance Concept for the SPL } \\
\text { Building }\end{array}$ \\
\hline & 012390 & File/Harrison & Attachment & $\begin{array}{l}\text { Telephone Conference between David } \\
\text { Kokalis, Wyman Harrison, and Herbert } \\
\text { Stevens - January } 19,1990\end{array}$ \\
\hline & & & Attachment & $\begin{array}{l}\text { O\&M Objectives ( } 2 \text { pgs) "Scoping The } \\
\text { Review" and "Steps in the Review" }\end{array}$ \\
\hline OM3 & 020690 & Morgan/Harrison & Letter & $\begin{array}{l}\text { Request for Review of the Operations and } \\
\text { Maintenance Concept for the Special } \\
\text { Process Laboratories (SPL) Building at Ft. } \\
\text { Meade, MD }\end{array}$ \\
\hline OM4 & 020690 & Jones/Harrison & Letter & $\begin{array}{l}\text { Request for Review of the Operations and } \\
\text { Maintenance Concept for the Special } \\
\text { Process Laboratories (SPL) Building at Ft. } \\
\text { Meade, MD }\end{array}$ \\
\hline OM5 & 020690 & Liarakos/Harrison & Letter & $\begin{array}{l}\text { Request for Review of the Operations and } \\
\text { Maintenance Concept for the Special } \\
\text { Process Laboratories (SPL) Building at Ft. } \\
\text { Meade, MD }\end{array}$ \\
\hline OM6 & 020690 & Harrison/Harrison & Memo & $\begin{array}{l}\text { Request for Review of the Operations and } \\
\text { Maintenance Concept for the Special } \\
\text { Process Laboratories (SPL) Building at Ft. } \\
\text { Meade, MD }\end{array}$ \\
\hline OM7 & 020690 & Cunningham/Harrison & Letter & $\begin{array}{l}\text { Request for Revicw of the Operations and } \\
\text { Maintenance Concept for the Special } \\
\text { Process Laboratories (SPL) Building at Ft. } \\
\text { Meade, MD }\end{array}$ \\
\hline
\end{tabular}


INDEX FOR CORRESPONDENCE FILE 1.4.4 (RNSAOO-OM)

Documents Outgoing to Other Than NSA

(Cont'd)

\begin{tabular}{|c|c|c|c|c|}
\hline RNSAOO- & Dated/Rcvd & To/From & Description & Subject \\
\hline OM8 & 020690 & Musko/Harrison & Letter & $\begin{array}{l}\text { Request for Review of the Operations and } \\
\text { Maintenance Concept for the Special } \\
\text { Process Laboratories (SPL) Building at Ft. } \\
\text { Meade, MD }\end{array}$ \\
\hline OM9 & 020690 & Shepard/Harrison & Lotter & $\begin{array}{l}\text { Request for Review of the Operations and } \\
\text { Maintenance Concept for the Special } \\
\text { Process Laboratories (SPL) Building at Ft. } \\
\text { Meade, MD }\end{array}$ \\
\hline OM10 & 020690 & Stevens/Harrison & Memo & $\begin{array}{l}\text { Request for Revicw of the Operations and } \\
\text { Maintenance Concept for the Special } \\
\text { Process Laboratories (SPL) Building at. Ft. } \\
\text { Meade, MD }\end{array}$ \\
\hline OM11 & 031290 & Musko/Harrison & Memo & $\begin{array}{l}\text { Concurrence Review of ANL's Draft } \\
\text { Review on NSA's Operations and } \\
\text { Maintenance Concept for the SPL } \\
\text { Building }\end{array}$ \\
\hline OM12 & 031290 & Stevens/Harrison & Memo & $\begin{array}{l}\text { Concurrence Review of ANL's Draft } \\
\text { Review on NSA's Operations and } \\
\text { Maintenance Concept for the SPL } \\
\text { Building }\end{array}$ \\
\hline OM13 & 31290 & Harrison/Harrison & Memo & $\begin{array}{l}\text { Concurrence Review of ANL's Draft } \\
\text { Review on NSA's Operations and } \\
\text { Maintenance Concept for the SPL } \\
\text { Building }\end{array}$ \\
\hline OM14 & 031290 & Cunningham/Harrison & Letter & $\begin{array}{l}\text { Concurrence Review of ANL's Draft } \\
\text { Review on NSA's Operations and } \\
\text { Maintenance Concept for the SPL } \\
\text { Building }\end{array}$ \\
\hline OM15 & 031290 & Jones/Harrison & Letter & $\begin{array}{l}\text { Concurrence Review of ANL's Draft } \\
\text { Review on NSA's Operations and } \\
\text { Maintenance Concept for the SPL } \\
\text { Building }\end{array}$ \\
\hline OM16 & 031290 & Liarakos/Harrison & Letter & $\begin{array}{l}\text { Concurrence Review of ANL's Draft } \\
\text { Review on NSA's Operations and } \\
\text { Maintenance Concept for the SPL } \\
\text { Building }\end{array}$ \\
\hline OM17 & 031290 & Morgan/Harrison & Letter & $\begin{array}{l}\text { Concurrence Review of ANL's Draft } \\
\text { Review on NSA's Operations and } \\
\text { Maintenance Concept for the SPL } \\
\text { Building }\end{array}$ \\
\hline
\end{tabular}


INDEX FOR CORRESPONDENCE FILE 1.4.4 (RNSAOO-OM)

Documents Outgoing to Other Than NSA

(Cont'd)

\begin{tabular}{|c|c|c|c|c|}
\hline RNSAOO- & Dated/Rcvd & To/From & Description & Subject \\
\hline OM18 & 031290 & Shepard/Harrison & Memo & $\begin{array}{l}\text { Concurrence Review of ANL's Draft } \\
\text { Review on NSA's Operations and } \\
\text { Maintenance Concept for the SPL } \\
\text { Building }\end{array}$ \\
\hline OM19 & 031290 & File/Harrison & Draft Copy & $\begin{array}{l}\text { Review of NSA's Operations and } \\
\text { Maintenance Concepts for the Special } \\
\text { Process Laboratories Building, Ft. Meade, } \\
\text { Maryland (draft) }\end{array}$ \\
\hline OM20 & 031990 & Cunningham/Harrison & Concurrence & $\begin{array}{l}\text { Concurrence Review of ANL's Draft } \\
\text { Review Report on NSA's Operations and } \\
\text { Maintenance Concepts for the SPL } \\
\text { Building }\end{array}$ \\
\hline $\mathrm{OM} 21$ & 031990 & Musko/Harrison & Concurrence & $\begin{array}{l}\text { Concurrence Review of ANL's Draft } \\
\text { Review Report on NSA's Operations and } \\
\text { Maintenance Concepts for the SPL } \\
\text { Building }\end{array}$ \\
\hline OM22 & 031990 & Shepard/Harrison & Concurrence & $\begin{array}{l}\text { Concurrence Review of ANL's Draft } \\
\text { Review Report on NSA's Operations and } \\
\text { Maintenance Concepts for the SPL } \\
\text { Building }\end{array}$ \\
\hline OM23 & 032390 & QA File/Harrison & Memo & $\begin{array}{l}\text { Unrequested Comments Provided on Draft } \\
\text { ANL Review Report by NSA's Robert } \\
\text { Spriggs }\end{array}$ \\
\hline
\end{tabular}


$53 / 54$

1.5 NSA-Sponsored Formal Reviews 
DOCUMENTS PERTAINING TO THE NSA-SPONSORED FORMAL PERFORMANCE REVIEW OF NATIONAL SEMICONDUCTOR'S (NSC'S) PROPOSED ENHANCEMENTS TO THE CLEAN ROOM SYSTEMS LOCATED IN NSA'S SPL BUILDING AT FT. MEADE, MARYLAND 1.5 .1

\begin{tabular}{|c|c|c|c|c|}
\hline FILE- & Dated/Rcvd & To/From & Description & Subject \\
\hline NSAOO-001 & 013089 & Stevens/Harrison & Memo & $\begin{array}{l}\text { Session Chairmanship for Performance Review } \\
\text { of National Semiconductor's (NSC) Proposed } \\
\text { Enhancements to the Clean Room Systems } \\
\text { Located in the NSA Building at Ft. Meade, } \\
\text { Maryland }\end{array}$ \\
\hline NSAOO-003 & 013189 & Stevens/Harrison & Mcmo & $\begin{array}{l}\text { Request for Technical Revicw of NSC's } \\
\text { Enhancements to the Clean Room Systems at } \\
\text { the NSA's Special Process Laboratories, Fl. } \\
\text { Meade, Maryland }\end{array}$ \\
\hline NSAIO-002 & 020189 & File/Harrison & Memo & Signature Authorization for P.A. Kulzer \\
\hline NSAIO-001 & 020389 & File/Harrison & Memo & Scoping the Technical Review \\
\hline NSAOO-004 & 020689 & Gerbig/Stevens & Memo & $\begin{array}{l}\text { Background Information (pertinent specilications } \\
\text { and layout drawings) for NSC Proposed } \\
\text { Enhancements to Clean Room Systems in the } \\
\text { SPL Building, Ft. Meade, Maryland }\end{array}$ \\
\hline NSAOO-005 & 020689 & Ma!ik/Stevens & Memo & $\begin{array}{l}\text { Information Packet for Performance Revicw of } \\
\text { NSC Proposed Enhancements to Clean Room } \\
\text { Systems Located in the NSA SPL Building at } \\
\text { Ft. Meade, Maryland }\end{array}$ \\
\hline NSAOO-006 & 020689 & Naegele/Stevens & Letter & $\begin{array}{l}\text { Information Packet for Performance Revicw of } \\
\text { NSC Proposed Enhancements to Clean Room } \\
\text { Systems Located in the NSA SPL Building at } \\
\text { Ft. Meade, Maryland }\end{array}$ \\
\hline NSAOO-007 & 020689 & Rapa/Stevens & Memo & $\begin{array}{l}\text { Information Packet for Performance Revicw of } \\
\text { NSC Proposed Enhancements to Clean Room } \\
\text { Systems Located in the NSA SPL Building at } \\
\text { Ft. Meade, Maryland }\end{array}$ \\
\hline NSAOO-008 & 020989 & Stevens/Harrison & Memo & $\begin{array}{l}\text { Request for Technical Revicw of National } \\
\text { Semiconductor's (NSC) Enhancements to the } \\
\text { Clean Room Systems at the Special Process } \\
\text { Laboratories Building, Ft. Meade, Maryland }\end{array}$ \\
\hline NSAOO-0)9 & 020989 & Harrison/Harrison & Memo & $\begin{array}{l}\text { Request for Technical Review of Natiomal } \\
\text { Semiconductor's (NSC) Enhancements to the } \\
\text { Clcan Room Systems at the Special Process } \\
\text { Laboratories Building, Ft. Meade, Maryland }\end{array}$ \\
\hline
\end{tabular}


DOCUMENTS PERTAINING TO THE NSA-SPONSORED FORMAL PERFORMANCE REVIEW OF NATYONAL SEMICONDUCTOR'S (NSC'S) PROPOSED ENHANCEMENTS TO THE CLEAN ROOM SYSTEMS LOCATED IN NSA'S SPL BUILDING AT FT. MEADE, MARYLAND 1.5 .1

\begin{tabular}{|c|c|c|c|c|}
\hline FILE- & Dated/Rcvd & To/From & Description & Subject \\
\hline NSAOO-010 & 02,0989 & Gerbig/Harrison & Letter & $\begin{array}{l}\text { Request for Technical Review of National } \\
\text { Semiconductor's (NSC) Enhancements to the } \\
\text { Clean Room Systems at the Special Process } \\
\text { Laboratories Building, Ft. Meade, Maryland }\end{array}$ \\
\hline NSAOO-011 & 020989 & Rapa/Harrison & Letter & $\begin{array}{l}\text { Request for Technical Review of National } \\
\text { Semiconductor's (NSC) Enhancements to the } \\
\text { Clean Room Systems at the Special Process } \\
\text { Laboratories Building, Fl. Meade, Maryland }\end{array}$ \\
\hline NSAOO-012 & 020989 & Naegele/Harrison & Letter & $\begin{array}{l}\text { Request for Technical Review of National } \\
\text { Semiconductor's (NSC) Enhancements to the } \\
\text { Clean Room Systems at the Special Process } \\
\text { Laboratories Building, Ft. Meade, Maryland }\end{array}$ \\
\hline NSAOO-016 & 020989 & Malik/Harrison & Memo & $\begin{array}{l}\text { Request for Technical Review of National } \\
\text { Semiconductor's (NSC) Enhancements to the } \\
\text { Clean Room Systems at the Special Process } \\
\text { Laboratories Building, Ft. Meade, Maryland }\end{array}$ \\
\hline NSAIO-004 & 030189 & File/Harrison & Memo & Signature Authorization for L. Narug \\
\hline
\end{tabular}


DOCUMENTS PERTAINING TO THE NSA-SPONSORED FORMAL PERFORMANCE REVILW OF THE DEIONIZED-WATER AND WASTEWATER-TREATMENT SYSTEMS LOCATED IN NSA'S SPL BUILDING AT FT. MEADE, MARYLAND

1.5 .2

\begin{tabular}{|c|c|c|c|c|}
\hline FILE- & Dated/Rcvd & To/From & Description & Subject \\
\hline NSAON-001 & 012589 & $\begin{array}{l}\text { Hoehn/Harrison, } \\
\text { Peters }\end{array}$ & Letter & $\begin{array}{l}\text { Sense-of-the-Meeting Report for the Tiger } \\
\text { Team's Review of the SPL's Delonized Water } \\
\text { System, Jan, } 18 / 19,1989\end{array}$ \\
\hline NSAOO-002 & 013089 & Peter/Harrison & Memo & $\begin{array}{l}\text { Session Chairmanship for Porformance Reviow } \\
\text { of NSC Proposed Enhancements to the } \\
\text { Deionization-Water System Located in the NSA } \\
\text { Building at Ft. Meade, Maryland }\end{array}$ \\
\hline NSAIO-002 & 020189 & File/Harrison & Memo & Signature Authorization for P. A. Kulzer \\
\hline NSAOO-013 & 020989 & Collentro/Harrison & Letter & $\begin{array}{l}\text { Request for Performance Review of National } \\
\text { Semiconductor's Enhancements to the National } \\
\text { Security Agency's (NSA's) Speclal Process } \\
\text { Laboratories, Ft. Meade, Maryland }\end{array}$ \\
\hline NSAOO-014 & 020989 & Harrison/Hurrison & Merno & $\begin{array}{l}\text { Request for Performance Review of National } \\
\text { Semiconductor's Enhancements to the National } \\
\text { Security Agency's (NSA's) Special Process } \\
\text { Laboratories, Fl. Mcadc, Maryland }\end{array}$ \\
\hline NSAOO-015 & 020989 & Peters/Harrison & Memo & $\begin{array}{l}\text { Request for Pertormance Review of Nationul } \\
\text { Semiconductor's Enhancements to the National } \\
\text { Security Agency's (NSA's) Special Process } \\
\text { Laboratorics, Fl. Meade, Maryland }\end{array}$ \\
\hline NSAIO-003 & 030289 & Harrison/Collentro & Letter & $\begin{array}{l}\text { Comments Regarding Facillty Enhancements at } \\
\text { the SPL, Ft. Meade, MD- Deionized-Water } \\
\text { Purification Systems }\end{array}$ \\
\hline NSAIO-004 & 030189 & File/Harrison & Memo & Signature Authorization for L. Narug \\
\hline
\end{tabular}


DOCUMENTS PERTAINING TO THE NSA.SPONSORED FORMAL PERFORMANCE REVIEW OF THE HIGH-PURITY-GAS PIPING SYSTEM LOCATED IN NSA'S SPL BUILDING A'T FT, MEADE, MARYLAND 1.5 .3

\begin{tabular}{lllll}
\hline FILE- & Dated/Revd & To/From & Description & Subject \\
\hline NSAIO-002 & 020189 & File/Harrison & Memo & Signature Authorization for P. A. Kulzer \\
NSAIO-004 & 030189 & File/Harrison & Momo & Signature Authorization for L. Narug \\
NSAIO-006 & 041789 & File & Report & $\begin{array}{l}\text { Preliminary Data from Slack Associates on } \\
\text { Leak Check of High-Purity-Gas Plpe System }\end{array}$
\end{tabular}


DOCUMENTS PERTAINING TO THE NSA-SPONSORED FORMAL PERFORMANCE REVIEW OF NSA'S OPERATIONS AND MAINTENANCE CONCEPT FOR THE SPL BUILDING 1.5 .4

\begin{tabular}{|c|c|c|c|c|c|}
\hline RNSA. & Dated & / Revd & To/From & Description & Subject \\
\hline IN-OM1 & 011290 & 011490 & Harrison/Kokalis & Lotter & $\begin{array}{l}\text { Request for Revicw of NSA's Operations } \\
\text { and Maintenance Concept for the SPL } \\
\text { Building }\end{array}$ \\
\hline IN-OM2 & 032390 & 040490 & Harrison/Kokalis & Memo & $\begin{array}{l}\text { Request for Final Draft of SPL O\&M } \\
\text { Review Report }\end{array}$ \\
\hline IO-OM1 & 033090 & & Jones/Harrison & Concurrence & $\begin{array}{l}\text { Concurrence Rovicw of ANL's Dralt } \\
\text { Review Report on NSA's Operations and } \\
\text { Maintenance Concepts lor the SPL } \\
\text { Building (Handwritterl suggestion) }\end{array}$ \\
\hline ON.OMl & 031290 & & Kokalis/Harrison & Letter & $\begin{array}{l}\text { Agency Manager's Revicw of Argonne's } \\
\text { Draft Review Report on NSA's Operations } \\
\text { and Maintenance Concepts for the SPL } \\
\text { Building }\end{array}$ \\
\hline ON-OM2 & 031290 & & Flle/Harrison & Draft Copy & $\begin{array}{l}\text { Review of NSA's Operations and } \\
\text { Maintenance Concepts for the Speclal } \\
\text { Process Laboratories Building. Ft. Meade, } \\
\text { Maryland }\end{array}$ \\
\hline ON.OM3 & 040590 & & Kokalis/Harrison & $\begin{array}{l}\text { Letter } \\
\text { Altachment }\end{array}$ & $\begin{array}{l}\text { Final Version of the ANL Review Report } \\
\text { on NSA's Operations and Maintenance } \\
\text { Concepts for the SPL Building } \\
\text { same as above }\end{array}$ \\
\hline OO-OM1 & 011890 & 011890 & Stevens/Harrison & Altachments & $\begin{array}{l}\text { Your Designation as Review Session } \\
\text { Chairman for the ANL.Conducted Peer } \\
\text { Review of NSA's Operations and } \\
\text { Maintenance Concept for the SPL Building } \\
\text { Beneficial Occupancy Date, Fll-Up } \\
\text { Contracting, } 100 \% \text { Government Operation, } \\
\text { Proposed Resourecs, Proposed } \\
\text { Organizational Structure }\end{array}$ \\
\hline OO-OM2 & $\begin{array}{l}012990 \\
011290 \\
012390\end{array}$ & 011490 & $\begin{array}{l}\text { File/Harrison } \\
\text { Harrison/Kokalis } \\
\text { File/Harrison }\end{array}$ & $\begin{array}{l}\text { Memo } \\
\text { Altachment } \\
\text { Altachment }\end{array}$ & $\begin{array}{l}\text { Scoping the Review Of the Operations and } \\
\text { Maintenance Concept for the SPL Building } \\
\text { Request for Revicw of NSA's Operations } \\
\text { and Maintenance Concept for the SPL } \\
\text { Building } \\
\text { Telephone Conference between David } \\
\text { Kokalis, Wyman Harrison, and Herbert } \\
\text { Stevens - January } 19,1990 \\
\text { O\&M Objectives (2 pgs) "Scoping the } \\
\text { Review" and "Steps in the Review" }\end{array}$ \\
\hline
\end{tabular}




\section{DOCUMENTS PERTAINING TO THE NSA-SPONSORED FORMAL PERHORMANCE REVIEW OF NSA'S OPERATIONS AND MAINTENANCE CONCER'T FOR THE SPL BUILDING}

\section{5 .4}

\begin{tabular}{|c|c|c|c|c|}
\hline RNSA- & Dated / Rcvd & 'To/From & Description & Subject \\
\hline OO-OM3 & 020690 & Morgan/Harrison & Letter & $\begin{array}{l}\text { Request for Revlew of the Operations and } \\
\text { Maintenance Concept for the Special } \\
\text { Process Laboratoriss (SPL) Building at Fl. } \\
\text { Meade, MD }\end{array}$ \\
\hline OO.OM4 & 020690 & Jones/Harrison & Letter & $\begin{array}{l}\text { Request for Reviow of the Operations and } \\
\text { Maintenance Concept for the Spectal } \\
\text { Process Laboratories (SPL) Building at Fi, } \\
\text { Meade, MD }\end{array}$ \\
\hline OO-OM5 & 020690 & Liarakos/Harrison & Letter & $\begin{array}{l}\text { Request for Review of the Operations and } \\
\text { Maintenance Concept for the Special } \\
\text { Process Laboratories (SPL) Building at Fl. } \\
\text { Meade, MD }\end{array}$ \\
\hline OO-OM6 & 020690 & Harrison/Haurison & Memo & $\begin{array}{l}\text { Request for Reviow of the Operations and } \\
\text { Maintenance Concept for the Special } \\
\text { Process Laboratories (SPL) Building at Fl. } \\
\text { Meade, MD }\end{array}$ \\
\hline 00-0M7 & 020690 & Cunningham/Harrison & Letter & $\begin{array}{l}\text { Request for Review of the Operations and } \\
\text { Maintenance Concept for the Special } \\
\text { Process Laboratories (SPL) Buildirig at Ft. } \\
\text { Meade, MD }\end{array}$ \\
\hline ОО.0M8 & 020690 & Musko/Harrison & Letter & $\begin{array}{l}\text { Request for Review of the Operations and } \\
\text { Maintenance Concept for the Special } \\
\text { Process Laboratorics (SPL) Building at Fl. } \\
\text { Meade, MD }\end{array}$ \\
\hline OO-OM9 & 020690 & Shepard/Harrison & Letter & $\begin{array}{l}\text { Request for Review of the Operations and } \\
\text { Maintenance Concept for the Special } \\
\text { Process Laboratories (SPL) Building at Ft. } \\
\text { Meade, MD }\end{array}$ \\
\hline OO-OM10 & 020690 & Stevens/Harrison & Memo & $\begin{array}{l}\text { Request for Review of the Operations and } \\
\text { Maintenance Concept for the Special } \\
\text { Process Laboratories (SPL) Building at Ft. } \\
\text { Meade, MD }\end{array}$ \\
\hline OO-OM11 & 031290 & Musko/Harrison & Memo & $\begin{array}{l}\text { Concurrence Review of ANL's Draft } \\
\text { Review on NSA's Operations and } \\
\text { Maintenance Concept for the SPL Building }\end{array}$ \\
\hline OO-OM12 & 031290 & Stcvens/Harrison & Merno & $\begin{array}{l}\text { Concurrence Review of ANL's Draft } \\
\text { Review on NSA's Operations and } \\
\text { Maintenance Concept lor the SPL Building }\end{array}$ \\
\hline (N)OM13 & 31290 & Harrison/Harrison & Memo & $\begin{array}{l}\text { Concurrence Review of ANL's Draft } \\
\text { Review on NSA's Operations and } \\
\text { Maintenance Concept for the SPL Building }\end{array}$ \\
\hline
\end{tabular}


DOCUMENTS PERTAINING TO THE NSA-SPONSORED FORMAL PERFORMANCE REVIEW OF NSA'S OPERATIONS AND MAINTENANCE CONCEPT FOR THE SPL BUILDING 1.5 .4

\begin{tabular}{|c|c|c|c|c|}
\hline RNSA- & Dated / Rcvd & To/From & Description & Subject \\
\hline OO-OM14 & 031290 & Cunningham/Harrison & Letter & $\begin{array}{l}\text { Concurrence Review of ANL's Draft } \\
\text { Review on NSA's Oferations and } \\
\text { Maintenance Concept for thi SPL Building }\end{array}$ \\
\hline OO-OM15 & 031290 & Jones/Harrison & Letter & $\begin{array}{l}\text { Concurrence Review of ANL's Draft } \\
\text { Review on NSA's Operations and } \\
\text { Maintenance Concept for the SPL Building }\end{array}$ \\
\hline OO-OM16 & 031290 & Liarakos/Harrison & Letter & $\begin{array}{l}\text { Concurrence Review of ANL's Draft } \\
\text { Review on NSA's Operations and } \\
\text { Maintenance Concept for the SPL Building }\end{array}$ \\
\hline OO-OM17 & 031290 & Morgan/Harrison & Letter & $\begin{array}{l}\text { Cowarrence Review of ANL's Draft } \\
\text { Review on NSA's Operations and } \\
\text { Maintenance Concepl tor the SPL Building }\end{array}$ \\
\hline OO-OM18 & 031290 & Shepard/Harrison & Memo & $\begin{array}{l}\text { Concurrence Review of ANL's Draft } \\
\text { Review on NSA's Operations and } \\
\text { Maintenance Concept for the SPL Building }\end{array}$ \\
\hline OO-OM19 & 031290 & File/Harrison & Draft Copy & $\begin{array}{l}\text { Review of NSA's Operations and } \\
\text { Maintenance Concepts for the Special } \\
\text { Process Laboratories Building, Ft. Mcadc, } \\
\text { Maryland (draft) }\end{array}$ \\
\hline OO-OM20 & 031990 & Cunningham/Harrison & Concurrence & $\begin{array}{l}\text { Concurrence Review of ANL's Draft } \\
\text { Review Report on NSA's Operations and } \\
\text { Maintenance Concepts for the SPL } \\
\text { Building }\end{array}$ \\
\hline OO-OM21 & 031990 & Musko/Harrison & Concurrence & $\begin{array}{l}\text { Concurrence Review of ANL's Draft } \\
\text { Review Report on NSA's Operations and } \\
\text { Maintenance Concepts for the SPL } \\
\text { Building }\end{array}$ \\
\hline OO-OM22 & 031990 & Shepard/Harrison & Concurrence & $\begin{array}{l}\text { Concurrence Review of ANL's Draft } \\
\text { Review Report on NSA's Operations and } \\
\text { Maintenance Concepts for the SPL } \\
\text { Building }\end{array}$ \\
\hline OO-OM23 & 032390 & QA File/Harrison & Memo & $\begin{array}{l}\text { Unrequested Comments Provided On Draft } \\
\text { ANL Review Repor' By NSA's Robert } \\
\text { Spriggs }\end{array}$ \\
\hline
\end{tabular}


6364

\subsection{NSA-Sponsored Informal Reviews}


INDEX OF DOCUMENTS PERTAINING TO THE NSA-SPONSORED INFORMAL REVIEW OF

PROPOSED ENHANCEI IENTS TO THE CLEAN ROOM SYSTEMS,

SPL BUILDING, FT. MEADE, MARYLAND

1.6.1

\begin{tabular}{|c|c|c|c|c|}
\hline FILE- & Datod/Rcud & To/From & Description & Subject \\
\hline NSAON-003 & 022389 & Soule/Harrison & Enclosure & $\begin{array}{l}\text { Argonne's Interim Review Report On National } \\
\text { Semiconductor Corporation's Enhancements to the } \\
\text { Clean Room Systems at the Special Process } \\
\text { Laboratories } \\
\text { Internal Document / Interim Review of National } \\
\text { Semiconductor Corp's Enhancements to the Clean } \\
\text { Room System at SPL, Ft. Meade }\end{array}$ \\
\hline NSAON-010 & 073189 & Kokalis/Harrison & $\begin{array}{l}\text { Letter } \\
\text { Attachment }\end{array}$ & $\begin{array}{l}\text { Informal Argonne Review of Clean Room } \\
\text { Construction at the SPL, July 20,1989 } \\
\text { Clean Room Construction at SPL, Progress } \\
\text { Review Trip, Gerbig }\end{array}$ \\
\hline NSAOO-001 & 010389 & Stevens/Harrison & Memo & $\begin{array}{l}\text { Session Chairmanship for Performance Review of } \\
\text { National Semiconductor's (NSC) Proposed } \\
\text { Enhancements to the Clean Room Systems } \\
\text { Located in the NSA Building Ft. Meade, MD }\end{array}$ \\
\hline NSAOO-003 & U13189 & Stevens/Harrison & Memo & $\begin{array}{l}\text { Request for Technical Review of National } \\
\text { Semiconductor's Enhancements to the Clean } \\
\text { Room Systems at the National Security Agency's } \\
\text { (NSA's) Special Process Laboratorics, Fl. Mcadc, } \\
\text { MD }\end{array}$ \\
\hline NSAOO-004 & 020689 & Gerbig/Stevens & $\begin{array}{l}\text { Memo } \\
\text { Enclosure } \\
\text { Enclosure } \\
\text { Enclosure }\end{array}$ & $\begin{array}{l}\text { Specifications and layout drawings for NSC's } \\
\text { proposed clean room system cnhancements } \\
\text { Same as alove } \\
\text { Construction Specifications NSC/SPL Ft. Meade, } \\
\text { MD Facility Enhancements / Package } 2 \text {. } \\
\text { Enhancements } \\
\text { Performance Review of the Clean Room Systems } \\
\text { at the SPL Building, Ft. Meade, MD }\end{array}$ \\
\hline NSACO-005 & 020689 & Malik/Stevens & Memo & $\begin{array}{l}\text { Information Packet for Performance Review of } \\
\text { NSC Proposed Enhancements to the Clean Room } \\
\text { Systems Located in the NSA Building, Ft. Meade, } \\
\text { MD }\end{array}$ \\
\hline NSAOAO-006 & 020689 & Naegele/Stevens & Letter & $\begin{array}{l}\text { Specification and layout drawings for NSC's } \\
\text { proposed clean room systems enhancements }\end{array}$ \\
\hline NSAOO-007 & 020689 & Rapid/Stevens & I.ctter & $\begin{array}{l}\text { Specification and layout drawings for NSC's } \\
\text { proposed clean room systems enhancements }\end{array}$ \\
\hline NSAOO-008 & 020989 & Stevens/Harrison & Memo & $\begin{array}{l}\text { Request for Technical Review of National } \\
\text { Semiconductor's (NSC) Enhancements to the } \\
\text { Clean Room Systems at the Special Process } \\
\text { Laboratories Building, Ft. Meade, MD }\end{array}$ \\
\hline
\end{tabular}


INDEX OF DOCUMENTS PERTAINING TO THE NSA-SPONSORED INFORMAL REVIEW OF PROPOSED ENHANCEMENTS TO THE CLEAN ROOM SYSTEMS,

SPL BUILDING, FT. MEADE, MARYLAND

1.6 .1

\begin{tabular}{|c|c|c|c|c|}
\hline FILE- & Dated/Rcvd & To/From & Description & Subject \\
\hline NSAOO-009 & 020989 & Harrison/Harrison & Memo & $\begin{array}{l}\text { Request for Technical Review of National } \\
\text { Semiconductor's (NSC) Enhancements to the } \\
\text { Clean Room Systems at the Special Process } \\
\text { Laboratories Building, Ft. Meade, MD }\end{array}$ \\
\hline NSAOO-010 & 020989 & Gerbig/Harrison & Letter & $\begin{array}{l}\text { Request for Technical Review of National } \\
\text { Semiconductor's (NSC) Enhancements to the } \\
\text { Clean Room Systems at the Special Process } \\
\text { Laboratories Building, Ft. Meade, MD }\end{array}$ \\
\hline NSAOO-011 & 020989 & Rapa/Harrison & Letter & $\begin{array}{l}\text { Request for Technical Review of National } \\
\text { Semiconductor's (NSC) Enhancements to the } \\
\text { Clean Room Systems at the Special Process } \\
\text { Laboratories Building, Ft. Meade, MD }\end{array}$ \\
\hline NSAOO-012 & 020989 & Naegele/Harrison & Letter & $\begin{array}{l}\text { Request for Technical Review of National } \\
\text { Semiconductor's (NSC) Enhancements to the } \\
\text { Clean Room Systems at the Special Process } \\
\text { Laboratories Building, Ft: Meade, MD }\end{array}$ \\
\hline NSAOO-016 & 020989 & Malik/Harrison & Memo & $\begin{array}{l}\text { Request for Technical Review of National } \\
\text { Semiconductor's (NSC) Enhancements to the } \\
\text { Clean Room System at the Special Process } \\
\text { Laboratories Building, Ft. Meade, MD }\end{array}$ \\
\hline NSAIO-001 & 020389 & File/Harrison & Memo & Scoping the Technical Review \\
\hline NSAIO-007 & 041789 & File/Rapa & Report & NSA Special Processing Lab - Design Comments \\
\hline NSAIO-015 & 072889 & File/Gerbig & Report & $\begin{array}{l}\text { Clean Room Construction at SPL, Ft. Mcade, } \\
\text { Progress Review Trip }\end{array}$ \\
\hline
\end{tabular}


INDEX OF DOCUMENTS PERTAINING TO THE NSA-SPONSORED INFORMAL REVIEW OF PACKAGE 5, ENVIRONMENTAL PROTECTION SYSTEMS ENHANCEMENTS, SPL BUILDING, FT. MEADE, MARYLAND

1.6 .2

\begin{tabular}{lllll}
\hline FILE- & Dated/Rcvd & To/From & Description & \multicolumn{1}{c}{ Subject } \\
\hline NSAIO-011 & 060789 & $\begin{array}{l}\text { File/ANL-NSA } \\
\text { Personnel }\end{array}$ & Addendum & Addendum 1 to Package 5 \\
NSAON-004 & 061689 & Kokalis/Harrison & $\begin{array}{l}\text { Letter } \\
\text { Altachment }\end{array}$ & $\begin{array}{l}\text { Informal Review of NSC's "Package 5" Spec } \\
\text { Informal Review of NSC's Package } 5\end{array}$ \\
NSAON-007 & 071789 & Kokalis/Harrison & Letter & $\begin{array}{l}\text { Final Version of ANL's Informal Revicw of } \\
\text { National Semiconductor Corporation's Package 5 }\end{array}$ \\
"Environmental Protection Systems" \\
Same as above
\end{tabular}


DOCUMENTS PERTAINING TO THE NSA-SPONSORED INFORMAL REVIEW OF THE
LIME-ADDITION SYSTEM FOR THE WASTEWATER-TREATMENT SYSTEM, SPL BUILDING,
FT, MEADE, MD 1.6 .3

\begin{tabular}{|c|c|c|c|c|}
\hline FLLE- & Dated/Rcvd & To/From & Description & Subject \\
\hline NSAON-028 & 083189 & Kokalis/Harrison & Letter & $\begin{array}{l}\text { Final Version of ANL's "Informal Review of } \\
\text { Problems with Lime Addition System and } \\
\text { Acid/Caustic Storage Tank Systems" in the SPL } \\
\text { Building }\end{array}$ \\
\hline & & & Enclosure & $\begin{array}{l}\text { Informal Review of Problems with the SPL } \\
\text { Building's Lime-Addition System and } \\
\text { Acid/Caustic Storage Tank System }\end{array}$ \\
\hline NSAOO-018 & 080989 & Peters/Harrison & Memo & $\begin{array}{l}\text { Informal Review of Problems with Lime- } \\
\text { Addition System (and ANL's Recommendations } \\
\text { for Problem Solutions) for the Wastewater- } \\
\text { Treatment System, SPL Building, Ft. Meade, } \\
\text { MD }\end{array}$ \\
\hline
\end{tabular}


INDEX OF DOCUMENTS PERTAINING TO THE NSA-SPONSORED INFORMAL REVIEW OF THE LEPCO/MEBES III DOCUMENT REVIEW, SPL BUILDING, FT. MEADE, MARYLAND 1.6 .4

\begin{tabular}{|c|c|c|c|c|}
\hline FILE- & Dated/Rcvd & To/From & Description & Subject \\
\hline NSAIO-009 & $051289 / 052289$ & Book & Submittal & Temperature Control Submittal for Ft. Meade \\
\hline NSAIO-029 & 040789 & Shepard & Memo & $\begin{array}{l}\text { LEPCO Document Review, SPL/NSA, Ft. } \\
\text { Meade, MD }\end{array}$ \\
\hline \multirow[t]{3}{*}{ NSAIN-004 } & 080989 & Kokalis/Quinlivan & & $\begin{array}{l}\text { LEPCO's response to deficiencies defined by } \\
\text { ANL }\end{array}$ \\
\hline & . & & Altachment & $\begin{array}{l}\text { Minutes of NSA/NSC Construction Mecting: } \\
\text { Date/Time: August } 8,1989 / 1:(0) \mathrm{pm} \\
\text { Ft. Mcade, MD }\end{array}$ \\
\hline & & Quinlivan/Kelicho & Attachment & RE; Ft. Meade MEBES Facility \\
\hline NSAON-014 & 080389 & Kokalis/Shepard & Memo & $\begin{array}{l}\text { Owner-Supplied Equipment for MEBES Area } \\
\text { (LEPCO Work Area) SPL/NSA, Ft. Meade, } \\
\text { MD }\end{array}$ \\
\hline
\end{tabular}


INDEX OF DOCUMENTS PERTAINING TO THE NSA-SPONSORED INFORMAL REVIEW OF THE ION EXCHANGE ASSOCIATES, INC., SPECIFICATIONS FOR MULTI-MEDIA FILTERS, SPL

BUILDING, FT. MEADE, MARYLAND

1.6.5

\begin{tabular}{lllll}
\hline FLLE- & DatedRevd & To/From & Description & \multicolumn{1}{c}{ Subject } \\
\hline NSAON-011 073189 & Kokalis/Harrison & Letter & $\begin{array}{l}\text { Informal Review of ION Exchange Associates, } \\
\text { Inc., Specifications for Multi-Media Filters } \\
\text { Technical Review of Specifications for } \\
\text { Multimedia Filters for the SPL Building's } \\
\text { Deionized-Water System }\end{array}$ \\
NSAIO-030 061589 & Malcy/Frederick & Atuchment & $\begin{array}{l}\text { Letter } \\
\text { First effort at producing a specification for the } \\
\text { procurement of multi-media filters for addition to } \\
\text { the SPL high-purity water-treatment system } \\
\text { Procurement Specification / Multi-Media Filter } \\
\text { Addition }\end{array}$
\end{tabular}


INDEX OF DOCUMENTS PERTAINING TO THE NSA-SPONSORED INFORMAL REVIEW OF THE PROPOSED ENHANCEMENTS TO THE DEIONIZED-WATER SYSTEM LOCATED IN THE NSA SPL BUILDING, FT. MEADE, MARYLAND

$$
1.6,6
$$

\begin{tabular}{lllll}
\hline FILE- & Dated/Rcvd & To/From & Description & \multicolumn{1}{c}{ Subject } \\
\hline NSAIN-008 & 091889 & Kokalis/Cunningham & Letter & D.I. Water Treatment System Enhancements \\
NSAIO-003 & 030289 & Harrison/Collentro & Letter & $\begin{array}{l}\text { Comments Regarding Facility Enhancements at } \\
\text { the Special Process Laboratories, Ft. Meade, } \\
\text { MD - Deionized-Water Purification System }\end{array}$ \\
NSAOO-002 & 013089 & Peters/Harrison & Mcmo & $\begin{array}{l}\text { Session Chairmanship for Performance Review } \\
\text { of National Semiconductor's (NSC) Proposed } \\
\text { Enhancements to the Deionization Water } \\
\text { System Located in the NSA Building, Ft. } \\
\text { Meade, MD }\end{array}$
\end{tabular}

NSAOO-013 $020989 \quad$ Collentro/Harrison Letter

Request for Performance Revicw of National Semiconductor's Enhancement to the DeionizedWater System at the National Security Agency's (NSA's) Special Process Laboratories, Ft. Meade, MD

NSAOO-014 $020989 \quad$ Harrison/Harrison Memo

Request for Performance Review of National Semiconductor's Enhancement to the DeionizedWater System at the National Security Agency's (NSA's) Special Process Laboratories, Ft. Meade, MD

NSAOO-015 $020989 \quad$ Peters/Harrison Letter

$\begin{array}{llll}\text { NSAON-001 } 012589 & \begin{array}{l}\text { Hoehn/Harrison/ Letter } \\ \text { RWP }\end{array}\end{array}$

Attachment A

Request for Performance Review of National Semiconductor's Enhancement to the DeionizedWater System at the National Security Agency's (NSA's) Special Process Laboratories, Ft. Meade, MD

Sense-of-the-Meeting Report for the Tiger Team's Review of the SPL's Deionized-Water System, January $18 / 19,1989 \ldots$

$\begin{array}{ll}\text { Attachment A } & \begin{array}{l}\text { ANL's Original Performance Review Report on } \\ \text { the Deionized-Water and Wastewater-Treatment } \\ \text { Systems }\end{array} \\ \text { Attachment B } & \begin{array}{l}\text { Process Flow Diagram of Enhancements A.greed } \\ \text { to by NSC, NSA \& ANL }\end{array} \\ \text { Attachment C } & \begin{array}{l}\text { Description of Enhancements Agreed to by } \\ \text { NSC, NSA \& ANL }\end{array} \\ \text { Attachment D } & \begin{array}{l}\text { ANL Commentary on Minimal Enhancements } \\ \text { Required to Produce Semiconductor Grade Water } \\ \text { and Expected Performance of Proposed }\end{array} \\ \text { Enclosure } & \begin{array}{l}\text { Enhancements } \\ \text { System Performance Review of the Deionized- } \\ \text { Water and Wastewater-Treatment Systems at the } \\ \text { Special Process Laboratories, Ft. Meade, MD }\end{array}\end{array}$


INDEX OF DOCUMENTS PERTAINING TO THE NSA.SPONSORED INFORMAL REVIEW OF THE SPL SPRINKLER SYSTEM, SPL BUILDING, FT. MEADE, MARYLAND

1.6.7

\begin{tabular}{|c|c|c|c|c|}
\hline FILE- & Dated/Rcrd & To/From & Description & Subject \\
\hline NSAIO-046 & $011890 / 021290$ & Shepard/Smith & $\begin{array}{l}\text { Memo } \\
\text { Enclosure }\end{array}$ & $\begin{array}{l}\text { Sprinkler System Serving the SPL } \\
\text { Building } \\
\text { Outline of problem with the SPL } \\
\text { sprinkler system..."Main line water } \\
\text { pressure has dropped below value } \\
\text { required to provide adequate sprinkler } \\
\text { coverage to the SPL Facillty. } \\
\text { Argonne to review the siluation and } \\
\text { recommend corrective action } \\
\text { required." }\end{array}$ \\
\hline NSAON-047 & 121189 & Kokalis/Shepard & Note & $\begin{array}{l}\text { Please write Wyman an } \\
\text { authorization note for an informal } \\
\text { review of the fire-protection systems } \\
\text { per our discussion. }\end{array}$ \\
\hline NSAON-048 & $121889 / 010390$ & Kokalis/Cunningham & Letter & $\begin{array}{l}\text { Sprinkler System Informal Revicw } \\
\text { for SPL Facility (Daled 18Dec89) }\end{array}$ \\
\hline NSAON-053 & $020990 / 021290$ & Kokalis/Shepard & Memo & $\begin{array}{l}\text { Contractor Quality Control, } \\
\text { Existing Sprinkler System in UL-E }\end{array}$ \\
\hline NSAON-054 & 022090 & Kokalis/Cunningham & Letuer & $\begin{array}{l}\text { Lower Level E Firc-Protection } \\
\text { System }\end{array}$ \\
\hline NSAOO-023 & $011890 / 012290$ & Rosenhan/Cunningham & Letter & $\begin{array}{l}\text { Please find criclosed the original } \\
\text { disks for } \mathrm{MC}^{\wedge} 2 \text { programs HP4M \& } \\
\text { HP6M... }\end{array}$ \\
\hline NSAOO-028 & 021690 & Cunningham/Rosenhan & Letter & $\begin{array}{l}\text { Fire flow calculations for NSA/SPL } \\
\text { building }\end{array}$ \\
\hline NSAIN-009 & 091889 & Kokalis/Cunningharn & Letuer & $\begin{array}{l}\text { Sprinkler System Calculation } \\
\text { Review }\end{array}$ \\
\hline NSAOO-029 & $032390 / 040490$ & Harrison/Rosenhan & Letuer & $\begin{array}{l}\text { NSA-SPL Sprinkler System } \\
\text { Analysis and Modifications }\end{array}$ \\
\hline NSAOO-030 & $033090 / 041690$ & Harrison/Rosenhan & $\begin{array}{l}\text { Letter } \\
\text { Allachments }\end{array}$ & $\begin{array}{l}\text { NSA-SPL Sprinkler System } \\
\text { Analysis and Modifications } \\
\text { Schematics, calculations, and } \\
\text { narrative material relating to the } \\
\text { analysis and proposed modifications } \\
\text { to the NSA-SPL Building sprinkler } \\
\text { system }\end{array}$ \\
\hline NSAON-055 & $041390 /(041690$ & Kokalis/Musko & Memo & SPL Sprinkler System Analysis \\
\hline
\end{tabular}


INDEX OF DOCUMEN'TS PERTAINING TO THE NSA-SPONSORED INIORMAL REVILW OF THE SPL SPRINKLER SYSTEM, SPL BUILDING, FT, MEADE, MARYLAND

1.6.7

\begin{tabular}{|c|c|c|c|c|}
\hline FILE- & Dated/Rcvd & To/From & Description & Subject \\
\hline NSAON -056 & $051890 / 052190$ & Kokalis/Shepard & Memo & $\begin{array}{l}\text { Response to L52 Comments } \\
\text { Regarding ANL/SPL Sprinkler } \\
\text { Systems Roview }\end{array}$ \\
\hline NSAIO-047 & $051690 / 052990$ & Cunningham/Shepard & Fax Truns & $\begin{array}{l}\text { T. Cunningham's response to project } \\
\text { roview comments made by Matt } \\
\text { Walch (L521) to Jerry Pogue } 5.14- \\
90 \text { (atuached) }\end{array}$ \\
\hline NSAON.057 & $060790 / 062.690$ & Kokalis/Shepard & Memo & $\begin{array}{l}\text { UL-E Sprinkler Shop Druwling } \\
\text { Review }\end{array}$ \\
\hline NSAON-059 & $070490 / 071690$ & Kokalis/Shepard & Memo & UL-E Sprinklor Review \\
\hline
\end{tabular}


INDEX OF DOCUMENTS PERTAINING TO THE NSA-SPONSORED INFORMAL REVIEW OF THE CHILLED WATER SYSTEM, SPL BUILDING, FT, MEADE, MARYLAND 1.6 .8

\begin{tabular}{|c|c|c|c|c|}
\hline FILE- & Dated/Rcvd & To/From & Description & Subject \\
\hline NSAON-058 & $062790 / 071690$ & Kokalis/McFadden & Lotter & $\begin{array}{l}\text { Preliminary Current Total Coollng Loads } \\
\text { For Chilled Water System }\left(42^{\circ} \mathrm{F} \text { Water) }\right. \\
\text { and Process Chilled Water System (390F. } \\
20 \% \text { Glycol/Water) }\end{array}$ \\
\hline NSAON-060 & $070990 / 071690$ & Kokalls/Shepard & Memo & NSA/NSC PSR Mecting 28Jun9) \\
\hline NSAON-061 & $072490 / 082390$ & Kokalis/McFadden & Letter & Sequencing of Chillers \\
\hline NSAON-062 & $080290 / 082390$ & Kokalis/McFoxdden & Letter & $\begin{array}{l}\text { Chilled Water System-Lowering of Chilled } \\
\text { Water Temperature }\end{array}$ \\
\hline
\end{tabular}


$75 / 76$

2 NON-QUALITY-ASSURED RECORDS OF PROJECT-RELATED DOCUMENTS 
$77 / 78$

\subsection{General Activities File}

(Documents are listed by date of receipt) 
GENERAL ACTIVITIES INDEX* 2.1

\begin{tabular}{|c|c|c|c|c|c|}
\hline GA- & Dated/ & Rcvd & To/From & Description & Subject \\
\hline 001 & 081089 & 033090 & Kokalis/Shepard & Memo & Specification Test Schedule \\
\hline \multirow[t]{2}{*}{002} & \multirow[t]{2}{*}{092089} & & Kokalis/Maley & Memo & $\begin{array}{l}\text { Occupancy Rating of Gas Storagc } \\
\text { Rooms }\end{array}$ \\
\hline & & & Kokalis/Etheredge & Attachment & $\begin{array}{l}\text { Declassification of the Gas Rooms } \\
\text { Air Changes in Gas Rooms } \\
\text { (calculations from Wagner Group } \\
\text { regarding the number of air } \\
\text { changes/hour) }\end{array}$ \\
\hline 003 & 101989 & & Kokalis/Cunningham & Letter & $\begin{array}{l}\text { Backpressure Control Valves For } \\
\text { D. I. System }\end{array}$ \\
\hline 004 & 101989 & & Kokalis/Cunningham & Merno & $\begin{array}{l}\text { Request for information: SPL } \\
\text { maintenance plan that includes the } \\
\text { operation and maintenance of the DI } \\
\text { Water System }\end{array}$ \\
\hline 0,5 & 102089 & & Kokalis/Shepard & Memo & $\begin{array}{l}\text { Union Carbide Industrial Gases, Inc. } \\
\text { Drawings for Bulk Storagc Area } \\
\text { (Sheets MIDATL-D-89-01 through } \\
\text { O6) SPL/NSA, Ft. Meade, MD }\end{array}$ \\
\hline 006 & 102389 & & Kokalis/Cunningham & Memo & $\begin{array}{l}\text { SPL Acquisition Purchase } \\
\text { Description (requesting copics of } \\
\text { documents pertinent to) }\end{array}$ \\
\hline 007 & 102589 & & Kokalis/Shepard & Memo & Area C Sprinkler Esculchicons \\
\hline 008 & 102789 & & Kokalis/Shepard & $\begin{array}{l}\text { Memo } \\
\text { Attachment }\end{array}$ & $\begin{array}{l}\text { Insulated Flex Duct } \\
\text { TP15805-7.1.8.1b }\end{array}$ \\
\hline \multirow[t]{8}{*}{009} & \multirow[t]{8}{*}{102889} & & Kokalis/Shepard & Memo & $\begin{array}{l}\text { Contractor Quality Control, Test } \\
\text { Frocedures }\end{array}$ \\
\hline & & & Kokalis/Shepard & Altchd Memo & $\begin{array}{l}\text { Protective Grilles for HEPA Filters } \\
\text { (Dated } 180 \mathrm{C}(89) \text { ) }\end{array}$ \\
\hline & & & Kokalis/Shepard & Auchd Memo & $\begin{array}{l}\text { Liquid Hydrogen \& Nitrogen Bulk } \\
\text { Storage Area (Dated 180<189) }\end{array}$ \\
\hline & & & & Drawing & $\begin{array}{l}\text { Underground (hot water) Yard } \\
\text { Hydrant System }\end{array}$ \\
\hline & & & Kok_.is/Cunningham & Letter & $\begin{array}{l}\text { Meeting of Octobnr } 12 \text { on the High } \\
\text { Purity Piping (Da 170ct89) }\end{array}$ \\
\hline & & & Kokalis/Cunninghan، & Letter & $\begin{array}{l}\text { Budget Costs For Multimedia Filters } \\
\text { (Revd 160et89)(Dated 130ct89) }\end{array}$ \\
\hline & & & Kokalis/Sl:apard & Memo & $\begin{array}{l}\text { /NSA, Ft. Meade, MD (Revd } \\
\text { 39)(Dated 13Oct89) }\end{array}$ \\
\hline & & & Kokalis/Shepard & Memo & $\begin{array}{l}10,000 \text { Corridors (Revd } \\
160(89) \text { (Dated } 110 \mathrm{O}(89) \ldots\end{array}$ \\
\hline
\end{tabular}

Project-kelated Do zuments - General Activities 
GENERAL ACTIVITIES INDEX 2.1

(Cont'd)

\begin{tabular}{|c|c|c|c|c|c|}
\hline GA- & Dated/ & Revd & To/From & Description & Subject \\
\hline \multirow{12}{*}{. } & & & Kokalis/Shepard & Attchd Memo & Clean Room Corridors, SPL/NSA, \\
\hline & & & Kokalis/Shepard & Memo & $\begin{array}{l}\text { Paint Supplier for the SPL, } \\
\text { SPL/NSA Ft. Meade, MD (Rcvd } \\
\text { 160ct89)(Dated 090ct89) }\end{array}$ \\
\hline & & & Kokalis/Shepard & Memo & $\begin{array}{l}\text { Deficiency List } \\
\text { 160ct89)(Daked 09Oct89) }\end{array} \quad$ (Rcvd \\
\hline & & & & Attachment & Same as above \\
\hline & & & Kokalis/Shepard & Memo & $\begin{array}{l}\text { Painting for the SPL, NSA/SPL F. } \\
\text { Meade, MD (Dated 06Oct89) }\end{array}$ \\
\hline & & & Kavouris/Axelson & Attachment & $\begin{array}{l}\text { Information pertaining to the } \\
\text { coating/paint used in the SPL }\end{array}$ \\
\hline & & & Maginot/Kavourix & Attachment & $\begin{array}{l}\text { SPL Section } 09910 \text {, General } \\
\text { Painting Materials Submittal }\end{array}$ \\
\hline & & & Kokalis/Cunningham & Memo & $\begin{array}{l}\text { Reverse Osmosis System Opcration } \\
\text { (RO-503) (Dated 04Oct89) }\end{array}$ \\
\hline & & & Kokalis/Shepard & Memo & $\begin{array}{l}\text { Cleanliness Levels for UL-C (Dated } \\
040 c 189 \text { ) }\end{array}$ \\
\hline & & & Kokalis/Shepard & Memo & UL-E Fire Damper Installation \\
\hline & & & Kokalis/Shepard & Memo & $\begin{array}{l}\text { Marshall Group Schedule Dated } \\
\text { 21Jun89 (Dated 25Jul89) }\end{array}$ \\
\hline & & & Soule/Shepard & Memo & $\begin{array}{l}\text { Marshall Group Schedule Dated } \\
\text { 30May89(Dated 07Jul89) }\end{array}$ \\
\hline 010 & 103189 & & Kokalis/Shepard & Memo & $\begin{array}{l}\text { Vibration Isolation, SPL/NSA, Ft. } \\
\text { Meade, MD }\end{array}$ \\
\hline 011 & 110289 & & /Cunningham & & $\begin{array}{l}\text { Backwash Flowrates For Carbon } \\
\text { Beds }\end{array}$ \\
\hline 012 & 110289 & & Kokalis/Shepard & Memo & $\begin{array}{l}\text { Leak in Hot Water Heating System, } \\
\text { SPL/NSA, Ft. Meade, MD }\end{array}$ \\
\hline 013 & 110389 & & Kokalis/Cunningham & Merno & Preureatment Filters for D. I. System \\
\hline 014 & 110689 & & Kokalis/Cunningham & Memo & $\begin{array}{l}\text { Request for information: past } \\
\text { performance values of the SPL } \\
\text { Reverse Osmosis Units }\end{array}$ \\
\hline 015 & 110789 & & Kokalis/Cunningham & Memo & D. I. System Bcoster Pumps \\
\hline 016 & 111089 & & Kokalis/Musko & Memo & LEPCO Fault Current Calculations \\
\hline 017 & 111389 & & Kokalis/Musko & Memo & LEPCO Fault Current Calculations \\
\hline 018 & 111489 & & Kokalis/Missko & Memo & $\begin{array}{l}\text { PA and Intercom Conduit \& } \\
\text { Shielding Requirements }\end{array}$ \\
\hline 019 & 111789 & & Kokalis/CL-n.ngham & $\begin{array}{l}\text { Letter } \\
\text { Attachment }\end{array}$ & $\begin{array}{l}\text { Sprinkler Systems } \\
\text { NFPA Standard for tine Installation } \\
\text { of SprinkJer Systems }\end{array}$ \\
\hline
\end{tabular}


GENERAL ACTIVITIES INDEX 2.1

(Cont'd)

\begin{tabular}{|c|c|c|c|c|c|}
\hline GA- & Dated & Rcvd & To/From & Description & Subject \\
\hline 020 & 111789 & & Kokalis/Musko & Memo & $\begin{array}{l}\text { Square D Manual Starter; Deficiency } \\
785\end{array}$ \\
\hline 021 & 111789 & & Kokalis/Shepard & Memo & $\begin{array}{l}\text { UL-E Exit Egress, SPL/NSA Ft. } \\
\text { Meade, MD }\end{array}$ \\
\hline 022 & 112089 & & Kokalis/Shepard & Memo & $\begin{array}{l}\text { Air/Water Leaks, SPL/NSA Fl. } \\
\text { Meade, MD }\end{array}$ \\
\hline 023 & 112189 & & Kokalis/Musko & Memo & $\begin{array}{l}\text { Deficiency } 786 \text { Backup, Cable } \\
\text { Overcurrent Protection }\end{array}$ \\
\hline 024 & 110889 & & Cunningham/Kokalis & Memo & Punch List For Lower Level E \\
\hline 025 & 110989 & & Cunningham/Kokalis & Memo & Punch List For Lower Level E \\
\hline 026 & 112889 & 121089 & Kokalis/Cunningham & Letter & $\begin{array}{l}\text { Manufacturer's Representative during } \\
\text { Equipment Installation }\end{array}$ \\
\hline 027 & 112889 & 121089 & Kokalis/Cunningham & Letter & $\begin{array}{l}\text { Preliminary Specification Review of } \\
\text { Uitrafilter System }\end{array}$ \\
\hline 028 & 113089 & 121089 & Kokalis/Cunningham & Memo & Reverse $\Gamma$ osis Cleaning Plin \\
\hline 029 & 120189 & 121089 & Kokalis/Shepard & Memo & $\begin{array}{l}\text { Material/Labor } \\
\text { Substitutions/Delctions, First Phase } \\
\text { Punchlist Status, First Phase } \\
\text { Activity Report for Phase Two Usc } \\
\text { (attachments) }\end{array}$ \\
\hline 030 & 120189 & 121089 & Kokalis/Cunningham & Letter & Valving on Ultrafilter Systcm \\
\hline 031 & 121189 & 010390 & List/Nyman & Minutes & $\begin{array}{l}\text { Contractors Mecting Summary } \\
6 \text { December } 1989\end{array}$ \\
\hline 032 & 121189 & 010390 & Kokalis/Shepard & Memo & Steam Generator Installation \\
\hline 033 & 121489 & 010390 & Kokalis/Musko & $\begin{array}{l}\text { Memo } \\
\text { Attachments }\end{array}$ & $\begin{array}{l}\text { Review of NSC Proposed Intercom } \\
\text { System for Wing E } \\
\text { Sketches }\end{array}$ \\
\hline 034 & 122089 & 010390 & Kokalis/Cunningham & Letter & $\begin{array}{l}\text { Identification of Toxic Gas Sample } \\
\text { Tubing }\end{array}$ \\
\hline 035 & 122089 & 010390 & Kokalis/Musko & Memo & $\begin{array}{l}\text { Penetration into Electrical } \\
\text { Substation Room }\end{array}$ \\
\hline 036 & 122089 & 010390 & Kokalis/Musko & Memo & $\begin{array}{l}\text { SPL Facility Enhancements Package } \\
2 \text { Construction Major Electrical } \\
\text { Deficiencies }\end{array}$ \\
\hline
\end{tabular}


GENERAL ACTIVITIES INDEX 2.1

(Cont'd)

\begin{tabular}{|c|c|c|c|c|c|}
\hline GA- & Dated/ & Rcvd & To/From & Description & Subject \\
\hline 037 & 010990 & 012290 & Kokalis/Cunningham & Letter & $\begin{array}{l}\text { NSC/Pilchuck Memorandum On Gas } \\
\text { Line Certification Changes }\end{array}$ \\
\hline & $\begin{array}{l}010590 \\
010290\end{array}$ & & Kokalis-Maley/Olpin & $\begin{array}{l}\text { Atuchd Memo } \\
\text { Attachment }\end{array}$ & $\begin{array}{l}\text { Gas Line Certification Change } \\
\text { Questions and Clarifications to } \\
\text { Testing Specifications }\end{array}$ \\
\hline & 110289 & & Kokalis/Etheredge & Attchd Letter & $\begin{array}{l}\text { Specialty Gas Certification } \\
(13485.4 .3-13485.4 .7)\end{array}$ \\
\hline 038 & 011090 & 012290 & Kokalis/Cunningham & Letter & Modifications to AHU-3C \& 4C \\
\hline 039 & 011190 & 011790 & Kokalis/Cunningham & Letter & Pipe Penetrations into AHU-26 \\
\hline 040 & 011290 & 011790 & Kokalis/Musko & Memo & Declassification of LL-E \\
\hline 041 & 011690 & 012290 & Kokalis/Cunningham & Letter & $\begin{array}{l}\text { Submittal Requirements for } \\
\text { Ultrafilter and Mixed Beds }\end{array}$ \\
\hline 042 & 011690 & 012290 & Kokalis/Cunningham & Letter & Mixed Bed Polishing Vesscls \\
\hline 043 & 011790 & 012290 & Kokalis/Musko & Letter & $\begin{array}{l}\text { Guardian Gas Protection Burn Box } \\
\text { Installation }\end{array}$ \\
\hline 044 & 010690 & 011790 & File/Nyman & & $\begin{array}{l}\text { Deficiency List Items, Upper Level } \\
\text { E, Fire Sprinkler System }\end{array}$ \\
\hline & & & & Atlacniment & Blueprints \\
\hline 045 & 011990 & 012990 & Kokalis/Musko & Letter & Shutdown Procedure Violations \\
\hline 046 & 011990 & 012990 & Kokalis/Musko & Letter & $\begin{array}{l}\text { D.I. Equipment Conduit and Wiring } \\
\text { Installation }\end{array}$ \\
\hline 047 & 012590 & 012990 & Kokalis/Cunningham & Letler & $\begin{array}{l}\text { Results of a Short Review of the } \\
\text { HVAC Load on the Process Chiller }\end{array}$ \\
\hline 048 & 011990 & 021290 & Kokalis/Musko & Letter & Shutdown Procedurc Violations \\
\hline 049 & 012390 & 021290 & Kokalis/Shepard & Memo & $\begin{array}{l}\text { UL-E DI Steam and Condensate } \\
\text { Piping }\end{array}$ \\
\hline 050 & 012590 & 021290 & Kokalis/Cunningham & Letter & $\begin{array}{l}\text { Results of the Short Review of the } \\
\text { HVAC Load on the Process Chiller }\end{array}$ \\
\hline 051 & 020190 & 021290 & File & Minutes & Mccuing - CDA 1 Fabruary 1990) \\
\hline 052 & 020290 & 021290 & Kokalis/Musko & Memo & Intercom System for Wing E \\
\hline 053 & 020590 & 021290 & Kokalis/Shepara & Memo & Deficiency List Stalus - 05Fcb90) \\
\hline 054 & 020790 & 021290 & Kokalis/Cunningham & Letter & $\begin{array}{l}\text { National Semiconductor } \\
\text { Memorandum dated Jan. 27, } 1990 \\
\text { Compressed Air System }\end{array}$ \\
\hline
\end{tabular}


GENERAL ACTIVITIES INDEX 2.1

(Cont'd)

\begin{tabular}{|c|c|c|c|c|c|}
\hline GA- & Dated/ & Rcvd & To/From & Description & Subject \\
\hline 055 & 020790 & 021290 & Kokalis/Cunningham & Letter & $\begin{array}{l}\text { CDA System (the following } \\
\text { specifications apply...) }\end{array}$ \\
\hline 056 & 020790 & 021290 & Kokalis/Cunningham & Letter & $\begin{array}{l}\text { SPL Equipment Cooling Water } \\
\text { System (ECW) }\end{array}$ \\
\hline 057 & 020890 & 021290 & Kokalis/Shepard & Memo & $\begin{array}{l}\text { Contractor Quality Control, } \\
\text { Independent } \\
\text { Requirements }\end{array}$ \\
\hline 058 & 020990 & & Kokalis/Cunningham & Letter & $\begin{array}{l}\text { Preliminary DI Enhancement } \\
\text { Deficiency List. List will be updated } \\
\text { week of Feb. } 11\end{array}$ \\
\hline 059 & & 022390 & Pogue/Cunningham & Memo & $\begin{array}{l}\text { Project Review Comments / SPL } \\
\text { Booster Pumps }\end{array}$ \\
\hline 060 & 021390 & & File/Kokalis & Minutes & $\begin{array}{l}\text { Contractors Coordination Mecting } \\
\text { 13February } 1990\end{array}$ \\
\hline 061 & 021490 & 022390 & Kokalis/Cunningham & Letter & DI Enhancement Deficiency List \\
\hline 062 & 021990 & & File/Musko & Minutes & $\begin{array}{l}\text { Minutes of NSA/NSC SPL } \\
\text { Construction Mecting } \\
\text { Date/Time: February 19, 1990/1:00 } \\
\text { p.m. Place: NSA SPL Trailcr } \\
\text { Ft. Meade, MD }\end{array}$ \\
\hline 063 & 021990 & 022390 & Kokalis/Cunningham & Letter & Acceptance of CDA Compressor \\
\hline 064 & 022090 & & Kokalis/Cunningham & Letter & $\begin{array}{l}\text { Relocation of } \mathrm{H} 2 \text { Sensors (NSC } \\
\text { Memo } 2 / 15 / 90 \text { ) }\end{array}$ \\
\hline 065 & 022090 & 022390 & Kokalis/Shepard & Memo & Contractor Quality Control \\
\hline 066 & 022190 & 022390 & Kokalis/Shepard & Memo & CQC Meeting \\
\hline
\end{tabular}


GENERAL ACTIVITIES INDEX 2.1

(Cont'd)

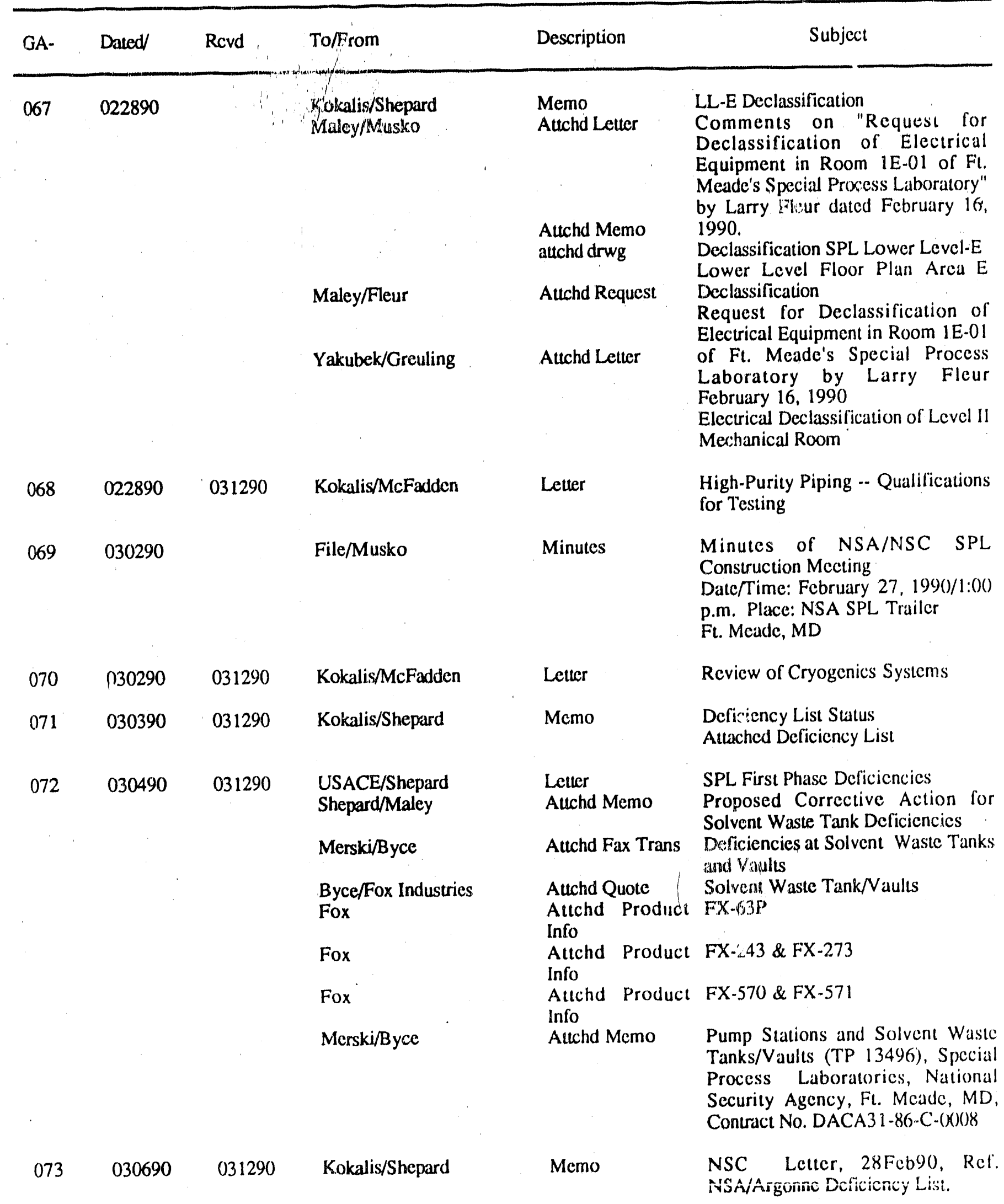


GENERAL ACTIVITIES INDEX 2.1

(Cont'd)

\begin{tabular}{|c|c|c|c|c|c|}
\hline GA- & Dated/ & Rcvd & To/From & Description & Subject \\
\hline 074 & 030790 & 0312,90 & $\begin{array}{l}\text { Kokalis/McFadden } \\
\text { Kokalis/Etheredge } \\
\text { Hewins/Jackman } \\
\text { Ramsey/Powers }\end{array}$ & $\begin{array}{l}\text { Letter } \\
\text { Attchd Memo } \\
\text { Attchd Memo } \\
\text { Attchd Memo }\end{array}$ & $\begin{array}{l}\text { Letter from R. Etheredge of } \\
\text { 02Mar90: "House Gas Line Testing" } \\
\text { House Gas Line Testing } \\
\text { Analytical Testing } \\
\text { Analytical Testing, Ft. Meade, MD }\end{array}$ \\
\hline 075 & (1)30790 & 031290 & Kokalis/McFadden & Letter & $\begin{array}{l}\text { Letter from R. Elheredge of 03039(): } \\
\text { "Equipment Cooling Water } \\
\text { Modifications and Testing" }\end{array}$ \\
\hline 076 & 030890 & 031290 & Peek/Shepard & Letter & $\begin{array}{l}\text { Potential for Argonne Produced } \\
\text { Instructional Training Programs and } \\
\text { Maintenance and Operations Plan for } \\
\text { Maintenance Systems Utilized to } \\
\text { Support the SPL Integrated Circuit } \\
\text { Chip and Circuit Board } \\
\text { Manufacturing Facility }\end{array}$ \\
\hline 077 & 030990 & 031290 & File/Kokalis & Draft Memo & $\begin{array}{l}\text { NSC Proposal Revicw, Spccial } \\
\text { Process Laboratory, NSA, Fi. } \\
\text { Meade, MD }\end{array}$ \\
\hline 078 & 030990 & 031090 & Kokalis/Shepard & Memo & $\begin{array}{l}\text { Suggested Independent Test } \\
\text { Laboratory Criteria, Special Process } \\
\text { Laboratory, NSA, Ft. Mcade, MD }\end{array}$ \\
\hline 079 & 030990 & 031990 & Kokalis/Musko & Letter & $\begin{array}{l}\text { Electrical Loads on the Emergency } \\
\text { Generator }\end{array}$ \\
\hline 080 & 031390 & 031990 & Kokalis/McFadden & Letter & $\begin{array}{l}\text { 1. Inspection of Service Chases } \\
\text { 2. Additional Comments on } \\
\text { Cryogenic Systems }\end{array}$ \\
\hline 081 & 031490 & 031990 & Kokalis/McFadden & Letter & $\begin{array}{l}\text { Inspection of Equipment Cooling } \\
\text { Water Pressure Testing }\end{array}$ \\
\hline 082 & 031490 & 031990 & $\begin{array}{l}\text { Kokalis/Shepard } \\
\text { Kokalis/Traverso }\end{array}$ & $\begin{array}{l}\text { Memo } \\
\text { Altchd Letwr }\end{array}$ & $\begin{array}{l}\text { NSC Summary Report Dated } \\
23 \text { Feb90 } \\
\text { SPL "Punch list" }\end{array}$ \\
\hline 083 & 031490 & 031990 & Kokalis/Shepard & Memo & $\begin{array}{l}\text { Annotated Deficiency Report, } \\
\text { 04May89 through } 12 \text { Oct } 90 \text { (actually } \\
04 \text { May88 through } 120 \text { ct } 89 \text { ) }\end{array}$ \\
\hline 084 & 031590 & 031990 & Kokalis/Musko & Letter & 480 Substation Cubicle Upgrade \\
\hline 085 & 022790 & 033090 & File/Kokalis & Minutes & $\begin{array}{l}\text { Contractors Coordination Mecting } \\
\text { 27February } 1990\end{array}$ \\
\hline 086 & 032090 & 033090 & Kokalis/McFadden & Letter & Review of Cryogenics Systems \\
\hline
\end{tabular}


GENERAL ACTIVITIES INDEX 2.1

(Cont'd)

\begin{tabular}{|c|c|c|c|c|c|c|}
\hline GA & Dated & Rcvd & To/From & & Description & Subject \\
\hline 087 & 031390 & 033090 & $\begin{array}{l}\text { Lewis [NSC]/Wade } \\
\text { [Wagner Group] }\end{array}$ & & Letter & Argonne Deficiency List Iterns \\
\hline 088 & 031390 & 033090 & File/Kokalis & & Minutes & $\begin{array}{l}\text { Contractors Coordination Mecting } \\
\text { 13March1990 }\end{array}$ \\
\hline 089 & 031690 & 033090 & Kokalis/McFadden & & Letter & $\begin{array}{l}\text { Inspection of Equipment Cooling } \\
\text { Water Pressure Testing }\end{array}$ \\
\hline 090 & 032190 & 033090 & Kokalis/Shepard & & $\begin{array}{l}\text { Memo } \\
\text { Attachments }\end{array}$ & $\begin{array}{l}\text { Duct Testing Procedures } \\
\text { same as above }\end{array}$ \\
\hline .091 & 032190 & $\begin{array}{l}033090 \\
051789 \\
\\
081889 \\
081489 \\
081089\end{array}$ & $\begin{array}{l}\text { Kokalis/Shepard } \\
\text { Soule/Shepard } \\
\text { Kokalis/Shepard } \\
\text { Kokalis/Quinliven } \\
\text { Jackman/Jansen }\end{array}$ & $i$ & $\begin{array}{l}\text { Memo } \\
\text { Auchd Memo } \\
\text { Auachment } \\
\text { Auchd Memo } \\
\text { Auchd Memo } \\
\text { Auchd Letter } \\
\text { Auachment } \\
\text { Fax trans } \\
\text { Attachment }\end{array}$ & $\begin{array}{l}\text { Exhaust Duct Testing } \\
\text { Contractor quality control } \\
\text { QCQ Section } 01400 \\
\text { NSC Proposed Duct Testing } \\
\text { Ductwork Testing } \\
\text { Testing of Ductwork } \\
\text { AABC Technical Publication } \\
\text { Duct Pressure Testing, Leakage Test } \\
\text { Kits (United McGill product info) } \\
\text { Wagner Group Response to Argonne } \\
\text { Deficiency List...attachments } \\
\text { cont'd... }\end{array}$ \\
\hline 092 & 032790 & 033090 & Kokalis/Musko & & Memo & $\begin{array}{l}\text { Comments on "Test Report } \\
\text { Summary" for the Special Process } \\
\text { Laboratory, Volume II, Facility } \\
\text { Enhancements, submitted by Wagner } \\
\text { Group and dated March 15, 1990. }\end{array}$ \\
\hline 093 & 032790 & 033090 & Kokalis/McFadden & & Letter & $\begin{array}{l}\text { Scrubbers-Low Water Float Switches } \\
\text { Attchd: sketches, East and West } \\
\text { Scrubbers }\end{array}$ \\
\hline 094 & 032890 & 033090 & Kokalis/McFadden & & Letter & $\begin{array}{l}\text { Process Exhaust Ductwork-Leak } \\
\text { Testing and Installation of Drains by } \\
\text { National Semicorductor }\end{array}$ \\
\hline 095 & 032990 & 03,3090 & Kokulis/Shepard & & Memo & $\begin{array}{l}\text { ECW System, Solvent Waste } \\
\text { Systems, and High Pressure } \\
\text { Laminate Boiler }\end{array}$ \\
\hline
\end{tabular}


GENERAL ACTIVITIES INDEX

2.1

(Cont'd)

\begin{tabular}{|c|c|c|c|c|c|}
\hline GA- & Dated/ & Revd & To/From & Description & Subject \\
\hline 096 & 032990 & 033090 & Kokalis/Musko & $\begin{array}{l}\text { Memo } \\
\text { Attachments }\end{array}$ & $\begin{array}{l}\text { Conduit Installation Requirements } \\
\text { Specification requirements for } \\
\text { installation of conduit in the SPL } \\
\text { Building, requirements for headroom } \\
\text { in Exit Corridors, Cutting and } \\
\text { Patching, Caulking and Sealants, and } \\
\text { conduit installation requirements } \\
\text { from the specifications for the } \\
\text { original building and Enhancement } \\
\text { package }\end{array}$ \\
\hline 097 & 032990 & 033090 & Kokalis/Shepard & Memo & $\begin{array}{l}\text { NSC SPL Enhancement Project } \\
\text { Meetings }\end{array}$ \\
\hline 098 & 032890 & 041090 & Lewis/Kokalis & $\begin{array}{l}\text { Fax trans } \\
\text { Attachments }\end{array}$ & $\begin{array}{l}\text { SPL Facility Erihancement } \\
\text { Wagner Enginecring Preliminary } \\
\text { New Catwalk Framing Plan } \\
\text { (Architectural Drawings) }\end{array}$ \\
\hline 99 & 040290 & 041090 & Kokalis/Musko & Memo & $\begin{array}{l}\text { Hydrogen Monitoring System } \\
\text { Trouble Alarm }\end{array}$ \\
\hline 100 & 040490 & 041090 & Kokulis/Musko & Memo & Hazardous Grounding Requirements \\
\hline 101 & 040490 & 041090 & Kokalis/Shepard & Memo & $\begin{array}{l}\text { Explosion Relief Panels Perimeter } \\
\text { Wall LL-E }\end{array}$ \\
\hline 102 & 040490 & 041090 & Kokalis/McFadden & Letter & $\begin{array}{l}\text { Hot Water Heating Valve in IL } \\
\text { Equipment Room, at ECW Pumping } \\
\text { Area }\end{array}$ \\
\hline 103 & 040590 & 041090 & Kokalis/Musko & Memo & $\begin{array}{l}\text { Electrical Service in LL-E Hazardous } \\
\text { Material Storage Areas }\end{array}$ \\
\hline 104 & 040590 & 041090 & File/Musko & Minutes & $\begin{array}{l}\text { Minutes of NSA/NSC SPL } \\
\text { Construction Meeting } \\
\text { Date/Time: April } 5,199(0 / 1: 00 \mathrm{pm} \\
\text { Place: NSA SPL Trailer, } \\
\text { Ft. Meade, MD }\end{array}$ \\
\hline 105 & 040690 & 041090 & Ko'alis/Shepard & Memo & Exhaust Nuct Sprinkler Layout \\
\hline \multirow[t]{2}{*}{106} & 041090 & 041390 & Kokalis/Shepard & Memo & $\begin{array}{l}\text { SPL. Test Report Summary, Volume } \\
11 \text {, submitted by Wagner Uroup, } \\
15 \text { MAR90 }\end{array}$ \\
\hline & 041090 & 041390 & Kokalis/Musko & Altachment & $\begin{array}{l}\text { Comments on "Test Report } \\
\text { Summary" for the Special Process } \\
\text { Laboratory, Volume 11, Facility } \\
\text { Enhancenicnts, submitted by Wagner } \\
\text { Group and dated March 15, 1990) }\end{array}$ \\
\hline
\end{tabular}


GENERAL ACTIVITIES INDEX 2.1

(Cont'd)

\begin{tabular}{|c|c|c|c|c|c|}
\hline GA- & Dated/ & Revd & To/From & Description & Subject \\
\hline & 032790 & & Kokalis/Musko & Attachment & $\begin{array}{l}\text { Comments on "Test Report } \\
\text { Summary" for the Special Process } \\
\text { Laboratory, Volume II, Facility } \\
\text { Enhancements, submitted by Wagner } \\
\text { Group and dated March } 15,1990 \\
\text { Special Process Laboratory Test } \\
\text { Report Summary, Volume II - } \\
\text { Facillty Enhancements, submitted by } \\
\text { Wagner Group, March 15, 1990) }\end{array}$ \\
\hline 107 & 041090 & 042490 & Kokalis/Musko & Memo & Conduit Labeling Requirements \\
\hline 108 & 041690 & 042490 & File/Musko & Memo & $\begin{array}{l}\text { Minutes of NSA/NSC SPL } \\
\text { Construction Mecting } \\
\text { Date/Time: April 10, 1990/1:00 pm } \\
\text { Place: NSA SPL Trailer, } \\
\text { Ft. Meade, MD }\end{array}$ \\
\hline 109 & 041790 & 042490 & Kokalis/Cunningham & Memo & $\begin{array}{l}\text { Vibration Monitors For SPL } \\
\text { Equipment }\end{array}$ \\
\hline 110 & 041790 & 042490 & Kokalis/Cunningham & Memo & $\begin{array}{l}\text { Pursuant to our conversation, please } \\
\text { refer to section } 1590()-2.12 \text { of the } \\
\text { Wagner specification... }\end{array}$ \\
\hline 111 & 041790 & 042490 & Kokalis/Cunningham & Memo & $\begin{array}{l}\text { Ultrapure Water System Variances } \\
\text { Requested by NSC }\end{array}$ \\
\hline 112 & 041890 & 042490 & Kokalis/Cunningham & Memo & DI Enhancement Deficiency List \\
\hline 113 & 041890 & 042490 & Kokalis/Cunningham & Memo & $\begin{array}{l}\text { Pcssible Future Variance Requests } \\
\text { on Ultrapure Water Systcir }\end{array}$ \\
\hline 114 & 041990 & 042490 & Kokalis/Cunningham & Memo & DI System Deficiencics \\
\hline 115 & 041990 & 042490 & Kokalis/Cunningham & $\begin{array}{l}\text { Memo } \\
\text { Attchd memo }\end{array}$ & $\begin{array}{l}\text { Status of Comments From Oct. } 12 \\
\text { High-Purity Piping Mecting } \\
\text { subject memo }\end{array}$ \\
\hline 116 & 040990 & 041690 & Kokalis/McFadden & Letter & $\begin{array}{l}\text { NSC transmittal of 09MAR9()-"SPL } \\
\text { Gas Line T'est and Certification" and } \\
\text { Horizon "Record of Pressure } \\
\text { Testing" }\end{array}$ \\
\hline 117 & 041090 & 04.1690 & Kokalis/McFadden & Letter & $\begin{array}{l}\text { ECW Piping in } 2 \mathrm{E}-\mathrm{S}() 3 \text { Service } \\
\text { Chase }\end{array}$ \\
\hline 118 & 041190 & 041690 & Kokalis/Musiko & Memo & $\begin{array}{l}\text { Deficiency List for SPL as of April } \\
10,1990 \\
\text { Altached Deficiency List }\end{array}$ \\
\hline
\end{tabular}


GENERAL AC'TIVITIES INDEX 2,1

(Cont'd)

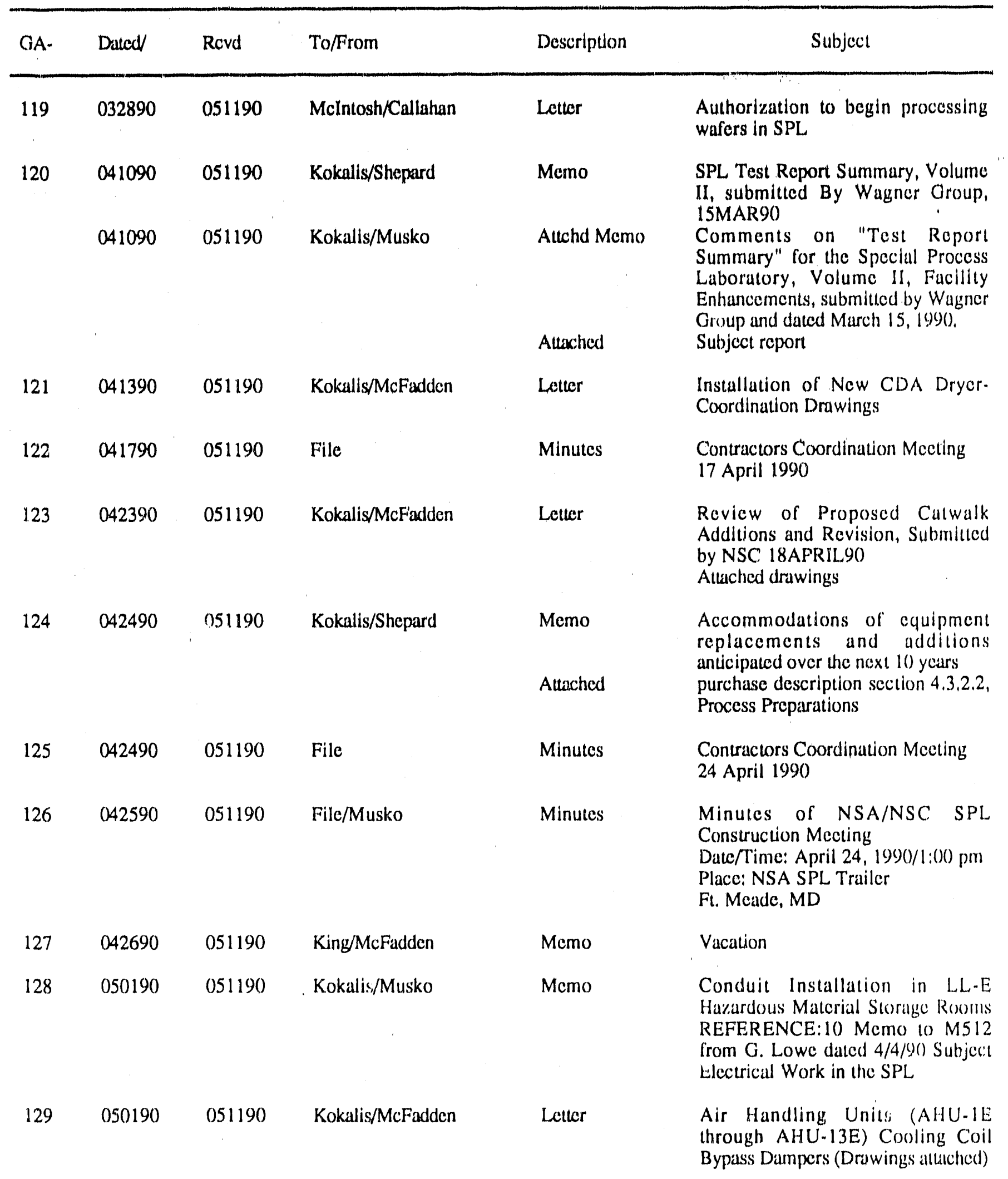


GENERAL ACTIVITIES INDEX 2.1

(Cont'd)

\begin{tabular}{|c|c|c|c|c|c|}
\hline GA- & Dated/ & Rcyd & To/From & Description & Subject \\
\hline 130 & 050490 & 051190 & Kokalis/Musko & Letter & $\begin{array}{l}\text { Circult Breaker Rating for Avallable } \\
\text { Fault Currents }\end{array}$ \\
\hline 131 & 050790 & 051190 & Kokalis/Shepard & Memo & $\begin{array}{l}\text { Response to A, C, D Project } \\
\text { "Requests For Information" SPL/ } \\
\text { NSA, Ft. Meade, MD }\end{array}$ \\
\hline 132 & 050190 & 051490 & File & Minutes & $\begin{array}{l}\text { Contractor Coordination Mecting, } \\
\text { 1May } 1990\end{array}$ \\
\hline 133 & 050790 & 051490 & File/Musko & Minutes & $\begin{array}{l}\text { Minutes of NSA/NSC SPL } \\
\text { Construction Meeting } \\
\text { Date/Time: May 1, 1990/1:00 pm } \\
\text { Place: NSA SPL Truiler } \\
\text { Ft. Meade, MD }\end{array}$ \\
\hline 134 & 050990 & 051490 & Kokalis/Shepard & Memo & $\begin{array}{l}\text { NSC To-Do Report } \\
\text { Attached List }\end{array}$ \\
\hline 135 & 050990 & 051490 & Kokalis/Shepard & Memo & $\begin{array}{l}\text { Deficiency Report } \\
\text { Attached Deficiency List }\end{array}$ \\
\hline 136 & 050990 & 051490 & Kokalis/McFaudden & Letter & Vibration Monitoris \\
\hline 137 & 051090 & 051490 & Kokalis/Musko & $\begin{array}{l}\text { Letter } \\
\text { Althd Letter } \\
\text { Altchd Memo }\end{array}$ & $\begin{array}{l}480 \text { Volt Sutistation Cubicle } \\
\text { Upgrade } \\
480 \text { Substation Cubicle Upgrade } \\
\text { Feasibility of using boltom cubicle } \\
\text { space in } 480 \text { Volt Section of Squarc } \\
\text { D substations }\end{array}$ \\
\hline 138 & 051090 & 051490 & Kokalis/Musko & Memo & T Com meeting on May 10,1990 \\
\hline 139 & 030890 & 052190 & File/Shepard & Transfer order & $\begin{array}{l}\text { Excess personal property, in place } \\
\text { transfer of truiler ANL } \# \text { P } 48558\end{array}$ \\
\hline 140 & 030890 & 05219 & File/Shepard & Transfer order & $\begin{array}{l}\text { Excess personal property, in place } \\
\text { transfer of trailer ANL \#P48558 } \\
\text { (Duplicate copy without notes) }\end{array}$ \\
\hline 141 & $(151590$ & 052190 & Kokalis/McFaudden & Letler & $\begin{array}{l}\text { Review and Comments on Wagner } \\
\text { Drwg. A-7A of Maly } 11 \text {, 1990, } \\
\text { "Existing and Proposed Now } \\
\text { Catwalk Framing Plan" }\end{array}$ \\
\hline 142 & 051690 & 052190 & Manslicld/Musko & Letter & $\begin{array}{l}\text { Latenc Defect in Power Factor } \\
\text { Correction Equipment }\end{array}$ \\
\hline
\end{tabular}


GENERAL ACTIVITIES INDEX 2.1

(Cont'd)

\begin{tabular}{|c|c|c|c|c|c|}
\hline GA. & Datedy & Revd & To/From & Description & Subject \\
\hline 143 & 051690 & 052190 & Kokallis/Musko & Lotter & $\begin{array}{l}\text { Power Factor Correction Equlpment } \\
\text { Deflciency, Reference: Momo to C. } \\
\text { Mansfield from M. Musko, sume } \\
\text { subject dated May 16, 1990. }\end{array}$ \\
\hline 144 & 051790 & 052190 & Kokalls/McFadden & Lotter & $\begin{array}{ll}\text { Comprossed } & \text { Dry Alr } \\
\text { (CDA)/Nitrogen } & \text { Switch.OVer } \\
\text { System } & \\
\text { (attached drawing) } & \end{array}$ \\
\hline 145 & 051790 & 052190 & Kokalis/McFadden & Lother & $\begin{array}{l}\text { Reviow of Nitrogen Stor"se Tank } \\
\text { and Local Nitrogen Piping }\end{array}$ \\
\hline 146 & 050890 & 052990 & Filo & Minutes & $\begin{array}{l}\text { Contractor Coordination Mecting } \\
8 \text { MAY } 1990\end{array}$ \\
\hline 147 & 051590 & 052990 & File & Minutes & $\begin{array}{l}\text { Contractor Coordination Mocting } \\
15 \text { MAY } 1990\end{array}$ \\
\hline 148 & 052190 & 052990 & Fille/Musko & Minutes & $\begin{array}{l}\text { Minutes of NSA/NSC SI'L } \\
\text { Construction Mecting } \\
\text { Date/Time: May } 15,199() / 1: 00 \mathrm{pm} \\
\text { Plaoc: NSA SPL Truiler } \\
\text { FL. Meade, MD }\end{array}$ \\
\hline 149 & 052290 & 052990 & Kokalis/McFadden & Letter & $\begin{array}{l}\text { Wator Systems in the SPL Building } \\
\text { - Rovised }\end{array}$ \\
\hline 150 & 052290 & 052990 & Kokalis/McFiadden & Letter & $\begin{array}{l}\text { Compressed Dry Air } \\
\text { (CDA)/Nitrogen Swilch-over } \\
\text { System. Changes Required As Part } \\
\text { of Enhancement Contract. }\end{array}$ \\
\hline & 052390 & 052990 & Kokalis/McFadden & Attchd Letter & $\begin{array}{l}\text { Compressed Air / Nitrogen Switch- } \\
\text { over System. Completion llems } \\
\text { Requirod As Part of Original } \\
\text { Contract. }\end{array}$ \\
\hline & 052190 & 052990 & Kokalis/McFadden & Attclid Letter & $\begin{array}{l}\text { Compressed Air/Nitrogen Switch- } \\
\text { over System. Further To Our Letter- } \\
\text { same subject-of } 17 \text { May9) } \\
5 \text { sketches attached }\end{array}$ \\
\hline 151 & 051690 & 060490 & Maiolo/Sangkavasi & Letter & SPL Punch List \\
\hline 152 & 052590 & 060490 & Kokalis/McFadden & Memo & $\begin{array}{l}\text { Final Review of Cryogenics Storage } \\
\text { Systems }\end{array}$ \\
\hline 153 & 053190 & 060490 & File/Musko & Minutes & $\begin{array}{l}\text { Minutes of NSA/NSC SPL } \\
\text { Construction Mecting } \\
\text { Date/Time: May } 29,199() / 1:(0) \mathrm{pm} \\
\text { Place: NSA SPL Trailer } \\
\text { Fl. Meade, MD }\end{array}$ \\
\hline
\end{tabular}


GLNERAL ACTIVITIES INDEX 2.1

(Cont'd)

\begin{tabular}{|c|c|c|c|c|c|}
\hline OA. & Dated/ & Revd & To/From & Description & Subject \\
\hline 154 & 053190 & 060490 & Fratus/Muloy & Lotter & $\begin{array}{l}\text { Ductwork Sprinkler Pluns for SPL, } \\
\text { Level 1, Area E }\end{array}$ \\
\hline 155 & 052990 & 062610 & Fillo & Minutes & $\begin{array}{l}\text { Contractor Coordination Mecting } 29 \\
\text { May } 1990\end{array}$ \\
\hline 156 & 060490 & 062690 & Kokalis/Shepard & Memo & Low-Temperature Chill Wuter Lcak \\
\hline 157 & 0604990 & 062690 & Kokalis/Shepard & Merno & Fillers for AHU-12E and $13 \mathrm{E}$ \\
\hline 158 & 060490 & 062690 & Kokalis/Shepard & Memo & $\begin{array}{l}\text { Halogenated/Non-Halogenatced Waste } \\
\text { Mains }\end{array}$ \\
\hline 159 & 060490 & 062690 & Kokalis/Shepard & Merno & Duct Exiling Makcup Air Unit-3 \\
\hline 160 & 060490 & 062690 & Kokalis/McFadden & Lotler & $\begin{array}{l}\text { Final Review of Cryogenics Storage } \\
\text { Systems }\end{array}$ \\
\hline 161 & 060890 & 062690 & Kokalis/Shepard & Memo & $\begin{array}{l}\text { Area E (1L-E) Class } 10,000 \text { Clean } \\
\text { Room Corridors }\end{array}$ \\
\hline 162 & 061190 & 062690 & Kokalis/Shepard & Memo & Nitrogen Backup for CDA \\
\hline 163 & 061190 & 062690 & Flle/Musko & Minutes & $\begin{array}{l}\text { Minutes of NSA/NSC SPL } \\
\text { Construction Mecting } \\
\text { Date/Time: June } 5,1990 / 1: 00 \mathrm{pm} \\
\text { Place: NSA SPL Trailer } \\
\text { Ft. Meade, MD }\end{array}$ \\
\hline 164 & 061290 & 062690 & File & Minutes & $\begin{array}{l}\text { Contractor Coordination Mecting } \\
12 \text { JUNE 1990) }\end{array}$ \\
\hline 165 & 061390 & 062690 & Kokalis/Musko & Letter & $\begin{array}{l}\text { Fire Alarm Junction Box in Corridor } \\
\text { 2D-(0) }\end{array}$ \\
\hline 166 & 061490 & 062690 & Kokalis/McFadden & Letter & $\begin{array}{l}\text { Leak in Equipment Cooling Water } \\
\text { (ECW) Piping }\end{array}$ \\
\hline 167 & 061890 & 062690 & Kokalis/Sl.epard & Memo & $\begin{array}{l}\text { ANL Deficiency List Rovicw } \\
\text { (14JUN9()) }\end{array}$ \\
\hline 168 & 062090 & 062690 & Kokalis/Musko & Memo & CDRL Ilem BOIS FoI SPL \\
\hline 169 & 061890 & 062690 & Kokalis/Shepard & Memo & $\begin{array}{l}\text { Deficiency Report } \\
\text { Altached report }\end{array}$ \\
\hline 170 & 062090 & 062690 & File/NSC (Savage) & Minutes & $\begin{array}{l}\text { History No. } 900619-() 1 \text { National } \\
\text { Semiconductor Corporation SPL } \\
\text { Facilities Quality Control Audit } \\
\text { CRSS Job \#11687.00) }\end{array}$ \\
\hline
\end{tabular}


GENERAL ACTIVITIES INDEX 2.1

(Cont'd)

\begin{tabular}{|c|c|c|c|c|c|}
\hline GA- & Dated/ & Rcvd & To/From & Description & Subject \\
\hline 171 & 062190 & 062690 & Kokalis/Shepard & Memo & $\begin{array}{l}\text { Swagelock Fittings in Cryogenic } \\
\text { Storage Area }\end{array}$ \\
\hline 172 & 062190 & 062690 & Kokalis/Shepard & Memo & Repairs for Doors and Hardware \\
\hline 173 & $\begin{array}{l}062290 \\
051690\end{array}$ & 071690 & $\begin{array}{l}\text { Kokalis/Shepard } \\
\text { Chief,R14/Slater }\end{array}$ & $\begin{array}{l}\text { Memo } \\
\text { Attchd Memo } \\
\text { Attchd Data }\end{array}$ & $\begin{array}{l}\text { NSA Quality Assurance Analysis of } \\
\text { SPL Clean rooms } \\
\text { Laminar Air Flow in the Special } \\
\text { Processing Laboratory } \\
\text { Air Flow Measurements }\end{array}$ \\
\hline 174 & 070390 & 071690 & Shepard/Cunningham & Fax Trans & "Summary of Situation" \\
\hline 175 & 070390 & 071690 & File & Minutes & $\begin{array}{l}\text { Contrartor Coordination Meeting } \\
3 \text { July } 1990\end{array}$ \\
\hline 176 & 070390 & 071690 & File & Minutes & $\begin{array}{l}\text { Contractor Coordination Mecting } \\
3 \text { July } 1990 \text { (not a duplicate of } \\
\text { above) }\end{array}$ \\
\hline 177 & 070590 & 071690 & Kokalis/ Shepard & Letter & $\begin{array}{l}\text { SPL Package } 5 \text { Deficiency Report } \\
\text { Summary }\end{array}$ \\
\hline 178 & 070990 & 071690 & Kokalis/Shepard & Memo & DI Water Mixed Bed Polisher. \\
\hline 179 & 071090 & 071690 & Kokalis/Shepard & Memo & LEPCO Installation \\
\hline 180 & 061990 & 071690 & File & Minutes & $\begin{array}{l}\text { Contractor Coordination Meeting } \\
19 \text { June } 1990\end{array}$ \\
\hline 181 & 070590 & 072390 & Moon/Bell & Letter & $\begin{array}{l}\text { Removal of items from ANL punch } \\
\text { list and deficiency list }\end{array}$ \\
\hline 182 & 070990 & 072390 & Kokalis/Shepard & Memo & NSA/NSC PSR Meeting 28Jun90 \\
\hline 183 & 071890 & 072390 & Kokalis/Shepard & Memo & Process Equipment Installation \\
\hline 184 & 071890 & 072390 & Kokalis/Shepard & $\begin{array}{l}\text { Memo } \\
\text { Attchd Specs }\end{array}$ & $\begin{array}{l}\text { Process Equipment Installation } \\
\text { Specification } \\
\text { NSC Process Equipment Installation } \\
\text { Specifications }\end{array}$ \\
\hline 185 & 071890 & 072390 & File/Musko & Minutes & $\begin{array}{l}\text { SPL Production Problems, L5 Tiger } \\
\text { Team Meeting, ANL Trailer, } 10:(0) \\
\text { A.M. }\end{array}$ \\
\hline 186 & 071390 & 072590 & File & Minutes & $\begin{array}{l}\text { History No. 900710-(01 National } \\
\text { Semiconductor Corporation SPL } \\
\text { Facilities Quality Control Audit } \\
\text { CRSS Job No. } 11687.00 \text {, } \\
\text { July } 10,1990\end{array}$ \\
\hline
\end{tabular}


GENERAL ACTIVITIES INDEX 2.1

(Cont'd)

\begin{tabular}{|c|c|c|c|c|c|}
\hline GA- & Dated/ & Revd & To/From & Description & Subject \\
\hline 187 & 072090 & 082390 & File & Minutes & $\begin{array}{l}\text { History No. } 900717-01 \text { National } \\
\text { Semiconductor Corporation, SPL } \\
\text { Facilities Quality Control Audit } \\
\text { CRSS Job No. } 11687-00\end{array}$ \\
\hline 188 & 072490 & 082390 & Kokalis/Shepard & Memo & $\begin{array}{l}\text { Deficiency Report, Special Process } \\
\text { Laboratory, National Security } \\
\text { Agency, Ft. Meade, Maryland }\end{array}$ \\
\hline 189 & 072790 & 082390 & File & Minutes & $\begin{array}{l}\text { Contractor Coordination Meeting } \\
\text { 27July } 1990\end{array}$ \\
\hline 190 & 073090 & 082390 & Kokalis/Shepard & Memo & $\begin{array}{l}\text { CRSS Lctter Dated 27July90 } \\
\text { (Regarding Unused Equipment } \\
\text { Supports Deficiencies Section) }\end{array}$ \\
\hline 191 & 073090 & 082390 & Kokalis/Shepard & Memo & $\begin{array}{l}\text { CRSS Letter Dated 27Jul90 } \\
\text { (Regarding Process Installation } \\
\text { Deficiencies Section) }\end{array}$ \\
\hline 192 & 073090 & 082390 & Kokalis/Shepard & Memo & $\begin{array}{l}\text { CRSS Letter Dated 27Jul90 } \\
\text { (Regarding Damages to SPL Facility } \\
\text { at Loading Dock 3B) }\end{array}$ \\
\hline 193 & 073090 & 082390 & Kokalis/Shepard & Memo & $\begin{array}{l}\text { CRSS Letter Dated 27Jul90 } \\
\text { (Regarding Item \#1155, Housc } \\
\text { Vacuum Deficiency) }\end{array}$ \\
\hline $\begin{array}{c}194 \\
\vdots \\
\vdots\end{array}$ & 073090 & 082390 & Kokalis/Shepard & Memo & $\begin{array}{l}\text { CRSS Letter Dated 27! u190) } \\
\text { (Regarding Item \#38 Duct, Testing } \\
\text { Deficiency) }\end{array}$ \\
\hline 195 & 073090 & 082390 & Kokalis/Shepard & Memo & $\begin{array}{l}\text { CRSS Letter Dated 27Jul9) } \\
\text { (Regarding Fire Protection } \\
\text { Deficiencies Section) }\end{array}$ \\
\hline 196 & 073090 & 082390 & Kokalis/Shepard & Memo & $\begin{array}{l}\text { SPL Acquisition Design Statement } \\
\text { of Work }\end{array}$ \\
\hline 197 & 073090 & 082390 & Kokalis/Shepard & Memo & SPL Safety Deficiency Resolutions \\
\hline 198 & & 082390 & Shepard/McFadden & Memo & $\begin{array}{l}\text { Package } 5 \text { - Make-up Air Units } \\
\text { GRU-1 and GRU-2 }\end{array}$ \\
\hline 199 & & 082390 & Shepard/McFadden & Memo & Air and Water Balance \\
\hline 200 & 080190 & 082390 & Kokalis/Musko & Lctuer & $\begin{array}{l}\text { Unauthorized Shutdown of Electrical } \\
\text { Power Reference: Memo from B. } \\
\text { Frist to B. Youden dated 27Jul90, } \\
\text { same subject as above (attached) }\end{array}$ \\
\hline
\end{tabular}


GENERAL ACTIVITIES INDEX

2.1

\section{(Cont'd)}

\begin{tabular}{|c|c|c|c|c|c|}
\hline GA- & Dated/ & Rcvd & To/From & Description & Subject \\
\hline 201 & 080190 & 082390 & Kokalis/Shepard & Memo & $\begin{array}{l}\text { Wagner Deviations (Amended } \\
\text { 03Aug90-ANL/LTS) }\end{array}$ \\
\hline 202 & 080290 & 082390 & Kokalis/Shepard & Memo & Oxygen Purifier (Redundancy) \\
\hline 203 & 080790 & 082390 & Kokalis/Musko & Memo & $\begin{array}{l}\text { Acceptance of Defective or Non- } \\
\text { Conforming Work }\end{array}$ \\
\hline 204 & 080790 & 082390 & File & Minutes & $\begin{array}{l}\text { Contractor Coordination Mecting } \\
7 \text { Aug90 }\end{array}$ \\
\hline 205 & 080890 & 082390 & Kokalis/Shepard & Memo & Clean Room Certification \\
\hline 206 & 080890 & 082390 & File/McFadden & Minutes & $\begin{array}{l}\text { Minutes of NSA/NSC SPL } \\
\text { Construction Meeting Date/Time: } \\
\text { 07Aug90 Place: NSA SPL Trailer, } \\
\text { Ft. Meade, MD }\end{array}$ \\
\hline 207 & 080890 & 082390 & Kokalis/Shepard & Memo & Air/Water Balance \\
\hline 208 & 081390 & 082390 & $\begin{array}{l}\text { McFadden/Stevens (Linde, } \\
\text { Union Carbide) }\end{array}$ & Fax tuans & $\begin{array}{l}\text { At your request and as a followup to } \\
\text { my July } 19,1990 \text { letter, presented } \\
\text { below is general information and } \\
\text { estimated pricing for Linde's nitrogen } \\
\text { generating plant that you had } \\
\text { expressed interest in.... }\end{array}$ \\
\hline 209 & 081490 & 082390 & File & Minutes & $\begin{array}{l}\text { Contractor Coorciination Mecting } \\
14 \text { August } 1990\end{array}$ \\
\hline 210 & 081590 & 082390 & Kokalis/McFadden & Letter & $\begin{array}{l}\text { Scrubbers-Traps for Scrubbers on } \\
\text { West Side of Building } \\
\text { (Autached drawing) }\end{array}$ \\
\hline 211 & 081590 & 082390 & File/McFadden & Minutes & $\begin{array}{l}\text { Minutes of NSA/NSC SPL } \\
\text { Construction Meeting Date/Time: } \\
14 \text { AUG90 Place: NSA SPL } \\
\text { Trailer, Ft. Meade, MD }\end{array}$ \\
\hline 212 & 081790 & 082390 & File & Minutes & $\begin{array}{l}\text { History No. 900814-01 National } \\
\text { Semiconductor Corporation, SPL } \\
\text { Facilities Quality Control Audit } \\
\text { CRSS Job No. } 11687 .(0)\end{array}$ \\
\hline 213 & 082090 & 082390 & Kokalis/Shepard & Memo & Deflecting Plenum Diffusers \\
\hline 214 & 082090 & 082390 & Kokalis/Musko & Letter & $\begin{array}{l}\text { Honcywell Computer in SPL } \\
\text { Control Room }\end{array}$ \\
\hline 215 & 082190 & 092490 & File & Minutes & $\begin{array}{l}\text { Contractor Coordination Mecting } \\
21 \text { August } 1990\end{array}$ \\
\hline
\end{tabular}


GENERAL ACTIVITIES INDEX 2.1

(Cont'd)

\begin{tabular}{|c|c|c|c|c|c|}
\hline GA- & Dated/ & Rcvd & To/From & Description & Subject \\
\hline 216 & 082290 & 092490 & Kokalis/Shepard & Memo & $\begin{array}{l}\text { Smoke Wall Penetrations } \\
\text { (Ductwork) }\end{array}$ \\
\hline 217 & 082490 & 092490 & Kokalis/McFadden & Letter & $\begin{array}{l}\text { Package } 5 \text { - Makeup Air Units GRU- } \\
1 \text { and GRU-2. Latent Deficiency }\end{array}$ \\
\hline 218 & 082790 & 092490 & File/Musko & Minutes & $\begin{array}{l}\text { Minutes of NSA/NSC SPL } \\
\text { Construction Meeting Date/Time: } \\
\text { August } 21,1990 / 1: 00 \text { p.m. Place: } \\
\text { NSA SPL Trailer, Ft. Mcade, MD }\end{array}$ \\
\hline 219 & 082790 & 092490 & Shepard/McFadden & Memo & Package 5 - Latent Deficiencies \\
\hline \multirow[t]{3}{*}{220} & 082990 & 092490 & Kokalis/McFadden & Letter & $\begin{array}{l}\text { D.I. Water System - Installation of } \\
\text { Automatic Backpressure Control } \\
\text { Valves in HQ and LQ Distribution } \\
\text { Systems }\end{array}$ \\
\hline & & & & Attchd Spec & $\begin{array}{l}\text { 15404-4; Fort Meade Spccial Process } \\
\text { Laboratories }\end{array}$ \\
\hline & & & Kokalis/Cunningham & Attchd Letter & $\begin{array}{l}\text { October } 13 \text { D. I. Water Mceting } \\
\text { (Dated } 170 \mathrm{Oc} 189 \text { ) }\end{array}$ \\
\hline 221 & 082990 & 092490 & File/McFadden & Minutes & $\begin{array}{l}\text { Minutes of NSA/NSC SPL } \\
\text { Construction Meeting Datc/Timc: } \\
\text { 28AUG } 90.1300 \mathrm{Hrs} \text {. Place: NSA } \\
\text { SPL Trailer, Ft. Meade, MD }\end{array}$ \\
\hline 222 & 083090 & 092490 & Kokalis/Musko & Letter & SPL Emergency Power System \\
\hline 223 & & 092490 & Shepard/McFadden & Memo & $\begin{array}{l}\text { Package } 5 \text { - Makeup Air Units GRU- } \\
1 \text { and GRU-2 (not dated) }\end{array}$ \\
\hline 224 & 090490 & 092490 & File & Minutes & $\begin{array}{l}\text { Contractor Coordination Meeting } \\
\text { 4September } 1990\end{array}$ \\
\hline 225 & 090490 & 092490 & File & Minutes & $\begin{array}{l}\text { Date/Time: September } 04,1990 / \\
\text { 1:00 p.m. Place: NSA SPL Trailer, } \\
\text { Ft. Meade, MD }\end{array}$ \\
\hline 226 & 091090 & 092490 & Kokalis/Musko & Memo & $\begin{array}{l}\text { Latent Defect SPL Wing E Electrical } \\
\text { Panelboard 3L } 16\end{array}$ \\
\hline 227 & 091190 & 092490 & Harrison/Shepard & Memo & $\begin{array}{l}\text { Recent Changes in NSA's } \\
\text { Implementation of ANL's Technical } \\
\text { Assistance Activities }\end{array}$ \\
\hline 228 & 091990 & 092490 & File & Minutes & $\begin{array}{l}\text { Contractor Coordination Mecting } \\
11 \text { September } 1990\end{array}$ \\
\hline 229 & 091390 & 092490 & Kokalis/Shepard & Memo & $\begin{array}{l}\text { Liquid Nitrogen (Cryogenics) } \\
\text { System }\end{array}$ \\
\hline
\end{tabular}




\section{(Cont'd)}

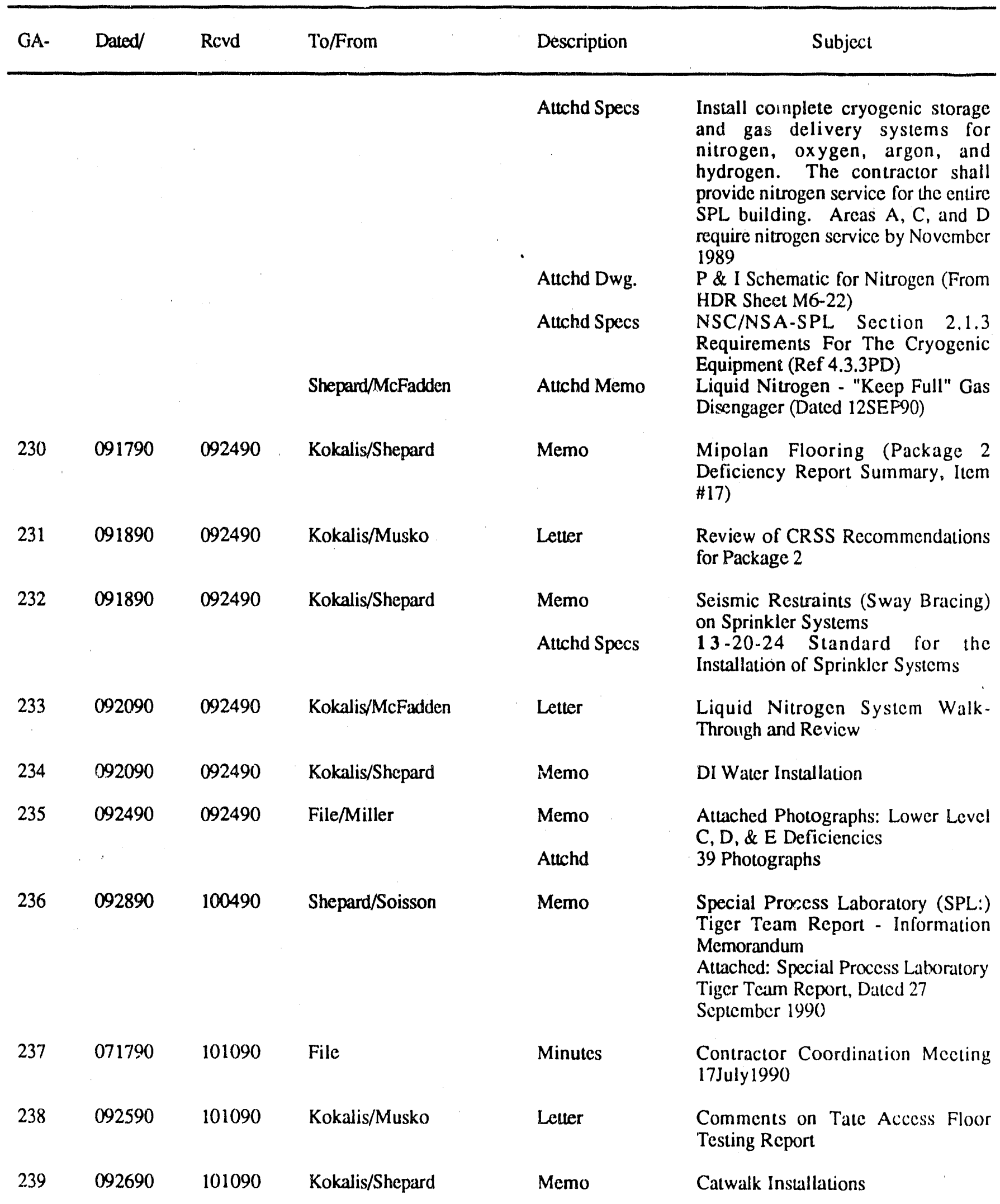


GENERAL ACTIVITIES INDEX 2.1

(Cont'd)

\begin{tabular}{|c|c|c|c|c|c|}
\hline GA- & Dated/ & Rcvd & To/From & Description & Subject \\
\hline 240 & 092690 & 101090 & Kokalis/Shepard & Memo & DI Water Mixed Beds \\
\hline 241 & 092690 & 101090 & Kokalis/Shepard & Memo & DI Water Heat Exchanger \\
\hline 242 & 100190 & 101090 & Kokalis/Shepard & $\begin{array}{l}\text { Memo } \\
\text { Attached }\end{array}$ & $\begin{array}{l}\text { Deficiency Report } \\
\text { Final Deficiency Report }\end{array}$ \\
\hline 243 & 100290 & 101090 & Kokalis/Shepard & Memo & $\begin{array}{l}\text { Re-Entrant Speakers for Firc } \\
\text { Detection and Alarm System }\end{array}$ \\
\hline 244 & 100290 & 101090 & Kokalis/Shepard & Memo & Public Address Speakers \\
\hline 245 & 102290 & 102290 & Kokalis/Shepard & Memo & $\begin{array}{l}\text { Tiger Team Report, Dated } 28 \text { SEP90 } \\
\text { (We have completed a cursory review } \\
\text { on the NSA tiger team report and } \\
\text { would offer the following } \\
\text { suggestions;...) }\end{array}$ \\
\hline 246 & 101890 & 102290 & Kokalis/Shepard & Memo & NHSW and HSW Drain Systems \\
\hline 247 & 091090 & & $\begin{array}{l}\text { Owens [NSC] / Savage } \\
\text { [CRSS] }\end{array}$ & $\begin{array}{l}\text { Letter } \\
\text { Autached }\end{array}$ & $\begin{array}{l}\text { SPL Facility Quality Control Audit } \\
\text { Monthly Report - August } 1990 \\
\text { Subject. report }\end{array}$ \\
\hline 248 & 102290 & 110190 & Kokalis/Shepard & Memo & Tiger Team Report, Dated 28SEP90 \\
\hline 249 & 102390 & 110190 & Kokalis/Shepard & Memo & $\begin{array}{l}\text { Make-Up Units 1, 2, and } 3 \\
\text { (Attachments: A; C, D Contract; } \\
\text { NSC As-Built Flow diagrarn) }\end{array}$ \\
\hline 250 & 102690 & 110190 & Kokalis/Shepard & Memo & $\begin{array}{l}\text { Make-Up Units 1, 2, and } 3 \\
\text { (Attachments: Original Eng Drwgs, } \\
\text { As Built. Drawing, Seneca Balance, } \\
\text { Inc., Diffuser and Grille Te.t Sheets) }\end{array}$ \\
\hline 251 & 110290 & 112190 & Kokalis/Shepard & Memo & As-Built Drawings \\
\hline 252 & 112990 & 112690 & Shepard/Harrison & $\begin{array}{l}\text { Memo } \\
\text { Attached }\end{array}$ & $\begin{array}{l}\text { National Semiconductor Corporation } \\
\text { Warranty Items for the SPL Facility } \\
\text { Enhancements } \\
\text { List }\end{array}$ \\
\hline 253 & 112790 & 112990 & Harrison/Shepard & Autached & $\begin{array}{l}\text { Draft Response From National } \\
\text { Semiconductor Corporation (NSC) } \\
\text { to National Security Agency (David } \\
\text { Kokalis, COR) in Regards to "NSC } \\
\text { Proposal Items Remaining" } \\
\text { Subject report }\end{array}$ \\
\hline
\end{tabular}

* Documents listed by date of reccipt 
$99 / 100$

\subsection{Project Activities File}


$101 / 102$

NSA / SPL PROJECT ACTIVITIES

Records of Meetings with R Group Staff 2.2

\begin{tabular}{llll}
\hline SPLPA- & Dated/Rcvd & To/From & Description \\
\hline
\end{tabular}

\begin{tabular}{|c|c|c|c|}
\hline 053190 & Harrison/Musko & Telecon Record & $\begin{array}{l}\text { Mike said that Linda had wanted only one } \\
\text { ANL person to attend the "weekly } \\
\text { construction meeting"... }\end{array}$ \\
\hline $082290 / 082390$ & Harrison/Shepard & Memo & $\begin{array}{l}\text { ANL Job Duties at the SPL (Per Linda } \\
\text { Soule, NSA,R 105,COR) } \\
\text { Attached: 1) Subject list "Argonne Job } \\
\text { Duties" 2) } 082290 / 082390>\text { Harrison } \\
\text { / Musko > Memo> Argonne SPL Job } \\
\text { Duties Defined by NSA }\end{array}$ \\
\hline
\end{tabular}

003

102390

File/Harrison

Telecon Record

NSA individual to whom ANL should transmit its QA Records File for the SPL Project 


\section{$103 / 104$}

2.3 Project Administration File 
PROJECT ADMINISTRATION FILE 2.3

NSA Informal Reviews

\begin{tabular}{lllll}
\hline PAF- & Dated & To/From & Description & Subject \\
\hline 001 & 120189 & File/Harrison & Memo & Custodial Change of QA Files \\
002 & 010290 & File/Miller & Memo & Reformatting Quality Assurance Files \\
003 & 031990 & File/Harrison & Memo & Discontinuing Use of Categories 3.1 and 3.2
\end{tabular}


$107 / 108$

2.4 Review of Request for Information (RFI)

Documents 
$109 / 110$

REVIEW OF REQUEST FOR INFORMATION (RFI) DOCUMENTS 2.4

\begin{tabular}{|c|c|c|c|c|c|}
\hline RFI- & Dated & Rcvd & To/From & Description & Subject \\
\hline 001 & 052489 & & Soule/Musko & Memo & Review of RFIs received to date \\
\hline 002 & 061389 & & Soule/Musko & Memo & $\begin{array}{l}\text { Review of RFIs received to date (REF.: memo } \\
\text { from Musko to Soule dated } 5 / 24 / 89 \text {, same } \\
\text { subject as above) }\end{array}$ \\
\hline 003 & 062989 & & Soule/Musko & Memo & $\begin{array}{l}\text { Review of RFIs received to date (REF.: memo } \\
\text { from Musko to Soule dated } 6 / 27 / 89 \text {, same } \\
\text { subject as above) }\end{array}$ \\
\hline 004 & 070689 & & Soule/Musko & Memo & $\begin{array}{l}\text { Review of RFIs received to date (REF.: memo } \\
\text { from Musko to Soule dated } 6 / 29 / 89 \text {, same } \\
\text { subject as above) }\end{array}$ \\
\hline 005 & 072689 & & Kokalis/Musko & Memo & $\begin{array}{l}\text { Review of RFIs received to date(REF.: memo } \\
\text { from Musko to Kokalis dated } 7 / 21 / 89 \text {, same } \\
\text { subject as above) }\end{array}$ \\
\hline 006 & 081089 & & Kokalis/Musko & Memo & $\begin{array}{l}\text { Review of RFIs received to date (REF.: memo } \\
\text { from M. Musko to } D \text {. Kolsalis dated } 7-26-89 \text {, } \\
\text { same subject as above) }\end{array}$ \\
\hline 007 & 100489 & & Kokalis/Musko & Memo & $\begin{array}{l}\text { Review of RFIs received to date (REF.: memo } \\
\text { from M. Musko dated } 8-10-69 \text {, same subject as } \\
\text { above) }\end{array}$ \\
\hline
\end{tabular}


$11 / / 112$

2.5 Monthly Reports

4 
$113 / 114$

MONTHLY REPORTS 2.5

\begin{tabular}{|c|c|c|c|c|c|}
\hline MR- & Dated & Rcvd & To/From & Description & Subject \\
\hline 001 & 071089 & & Harrison/Shepard & Memo & $\begin{array}{l}\text { ANL Monthly Report for } 06 / 89 \text {, Special } \\
\text { Process Laboratory, National Security Agency, } \\
\text { Ft. Meade, MD }\end{array}$ \\
\hline 002 & 080489 & 080489 & Harrison/Shepard & Memo & $\begin{array}{l}\text { ANL Monthly Report for } 07 / 89 \text {, Special } \\
\text { Process Laboratory, National Security Agency, } \\
\text { Ft. Meade, MD }\end{array}$ \\
\hline 003 & 101189 & 101689 & Harrison/Shepard & Memo & $\begin{array}{l}\text { ANL Monthly Report for } 9 / 89 \text { (September), } \\
\text { Special Process Laboratory, National Security } \\
\text { Agency, Ft. Meade, MD }\end{array}$ \\
\hline 004 & 120789 & 120789 & Harrison/Shepard & Memo & $\begin{array}{l}\text { ANL Monthly Report for } 10 / 89 \text {, Special } \\
\text { Process Laboratory, National Security Agency, } \\
\text { Ft. Meade, MD }\end{array}$ \\
\hline
\end{tabular}


$115 / 116$

\subsection{Weekly Reports}




\begin{tabular}{|c|c|c|c|c|c|}
\hline WR- & Dated & Rcvd & To/From & Description & Subject \\
\hline 001 & 050689 & & Soule/Shepard & Memo & $\begin{array}{l}\text { Weekly Report, Special Process Laboratory, } \\
\text { National Security Agency, Ft. Meade, MD }\end{array}$ \\
\hline 002 & 061289 & & Soule/Shepard & Memo & $\begin{array}{l}\text { Weekly Report, Special Process Laboratory, } \\
\text { National Security Agency, Ft. Mcade, MD }\end{array}$ \\
\hline 003 & 061289 & & Soule/Shepard & Memo & Marshall Group Schedule Dated 04APR89 \\
\hline 004 & 061289 & & Soule/Shepard & Memo & $\begin{array}{l}\text { Weekly Report, Special Process Laboratory, } \\
\text { National Sccurity Agency, Ft. Mcade, MD; } \\
\text { Corrected Copy }\end{array}$ \\
\hline 005 & 061489 & & Kokalis/Shepard & Memo & $\begin{array}{l}\text { Weekly Report, Special Process Laboratory, } \\
\text { National Security Agency, Ft. Mcade, MD }\end{array}$ \\
\hline 006 & 061689 & & Soule/Musko & Memo & $\begin{array}{l}\text { Weekly Report, Special Process Laboratory, } \\
\text { National Security Agency, Ft. Meade, MD }\end{array}$ \\
\hline 007 & 062989 & & & Memo & $\begin{array}{l}\text { Minutes of NSA/NSC We kly } \\
\text { Construction Meeting; Date: June 27, } 1989\end{array}$ \\
\hline 008 & 061689 & & Soule/Musko & Memo & $\begin{array}{l}\text { Weekly Report, Special Process Laboratory, } \\
\text { National Security Agency, Ft. Mcade, MD }\end{array}$ \\
\hline 009 & 063089 & & Soule/Musko & Memo & $\begin{array}{l}\text { Wcekly Report, Special Process Laboratory, } \\
\text { National Security Agency, Ft. Meade, MD }\end{array}$ \\
\hline 010 & 070589 & & & Memo & $\begin{array}{l}\text { Minutes of NSA/NSC Weckly } \\
\text { Construction Meeting; Date: July 5, } 1989\end{array}$ \\
\hline 011 & 070789 & & Soule/Musko & Memo & $\begin{array}{l}\text { Weekly Report, Special Process Laboratory, } \\
\text { National Security Agency, Ft. Meade, MD }\end{array}$ \\
\hline 012 & 071689 & 072389 & Kokalis/Shepard & Memo & $\begin{array}{l}\text { Weckly Report, Special Process Laboratory, } \\
\text { National Security Agency, Ft. Meade, MD }\end{array}$ \\
\hline 013 & 071989 & & & Memo & $\begin{array}{l}\text { Minutes of NSA/NSC Weckly } \\
\text { Construction Meeting; Datc: July } 18,1989\end{array}$ \\
\hline 014 & 072189 & & Kokalis/Musko & Memo & $\begin{array}{l}\text { Weekly Report, Special Process Laboratory, } \\
\text { National Security Agency, Ft. Mcade, MD }\end{array}$ \\
\hline 015 & 072889 & & Kokalis/Shepard & Memo & $\begin{array}{l}\text { Weekly Report, Special Process Laboratory, } \\
\text { National Security Agency, Ft. Mcadc, MD }\end{array}$ \\
\hline 016 & 080489 & & Kokalis/Musko & Memo & $\begin{array}{l}\text { Weckly Report, Spccial Process Laboratory, } \\
\text { National Sicurity Agency, Ft. Mcade, MD }\end{array}$ \\
\hline 017 & 081889 & & Kokalis/Musko & Memo & $\begin{array}{l}\text { Weckly Report, Special Process Laboratory, } \\
\text { National Sceurity Agency, Ft. Meade, MD }\end{array}$ \\
\hline 018 & 082589 & & Kokalis/Shepard & Memo & $\begin{array}{l}\text { Weckly Report, Special Process Laboratory, } \\
\text { National Security Agency, Ft. Meade, MD }\end{array}$ \\
\hline
\end{tabular}


WEEKLY REPORTS 2.6

(Cont'd)

\begin{tabular}{|c|c|c|c|c|c|}
\hline WR- & Dated & Rcvd & To/From & Description & Subject \\
\hline 019 & 090189 & & Kokalis/Musko & Memo & $\begin{array}{l}\text { Weekly Report, Special Process Laboratory, } \\
\text { National Security Agency, Ft. Meade, MD }\end{array}$ \\
\hline 020 & 091089 & & Kokalis/Shepard & Memo & $\begin{array}{l}\text { Weekly Report, Special Process Laboratory, } \\
\text { National Security Agency, Ft. Meade, MD }\end{array}$ \\
\hline 021 & 091589 & & Kokalis/Shepard & Memo & $\begin{array}{l}\text { Weekly Report, Special Process Laboratory, } \\
\text { National Security Agency, Ft. Meade, MD }\end{array}$ \\
\hline 022 & 092289 & & Kokalis/Shepard & Memo & $\begin{array}{l}\text { Weekly Report, Special Process Lahoratory, } \\
\text { National Security Agency, Ft. Meade, MD }\end{array}$ \\
\hline 023 & 092989 & & Kokalis/Musko & Merno & $\begin{array}{l}\text { Weekly Report, Special Process Laboratory, } \\
\text { National Security Agency, Ft. Meade, MD }\end{array}$ \\
\hline 024 & 100689 & 101689 & Kokalis/Shepard & Memo & $\begin{array}{l}\text { Weekly Report, Special Process Laboratory, } \\
\text { National Security Agency, Ft. Meade, MD }\end{array}$ \\
\hline 025 & 101389 & 101689 & Kokalis/Musko & Memo & $\begin{array}{l}\text { Weekly Report, Special Process Laboratory, } \\
\text { National Security Agency, Ft. Meade, MD }\end{array}$ \\
\hline 026 & 102789 & & Kokalis/Shepard & Memo & $\begin{array}{l}\text { Weekly Report, Special Process Laboratory, } \\
\text { National Security Agency, Ft. Meade, MD }\end{array}$ \\
\hline 027 & 111089 & & Kokalis/Shepard & Memo & $\begin{array}{l}\text { Weekly Report, Special Process Laboratory, } \\
\text { National Security Agency, Ft. Meade, MD }\end{array}$ \\
\hline 028 & 111789 & & Kokalis/Musko & Memo & $\begin{array}{l}\text { Weekly Report, Special Process Laboratory, } \\
\text { National Security Agency, Ft. Meade, MD }\end{array}$ \\
\hline 029 & 120489 & & Kokalis/Musko & Memo & $\begin{array}{l}\text { Weekly Report, Special Process Laboratory, } \\
\text { National Security Agency, Ft. Meade, MD }\end{array}$ \\
\hline 030 & 011690 & & Kokalis/Shepard & Memo & $\begin{array}{l}\text { Weekly Report, Special Process Laboratory, } \\
\text { National Security Agency, Ft. Meade, MD }\end{array}$ \\
\hline 031 & 040690 & 041090 & Kokalis/Musko & Memo & $\begin{array}{l}\text { Weekly Report. Special Process Laboratory, } \\
\text { National Security Agency, Ft. Meade, MD }\end{array}$ \\
\hline 032 & 041790 & 042490 & Kokalis/Musko & Memo & $\begin{array}{l}\text { Weekly. Report, Special Process Laboratory, } \\
\text { National Security Agency, Ft. Meade, MD }\end{array}$ \\
\hline
\end{tabular}


$119 / 120$

\subsection{Daily Reports}


DAILY REPORTS 2.7

\begin{tabular}{|c|c|c|c|c|c|}
\hline DR- & Dated & Rcvd & To/From & Description & Subject \\
\hline 001 & 061589 & 062089 & Soule/Shepard & Memo & $\begin{array}{l}\text { Daily Report, Special Process Laboratory, } \\
\text { National Security Agency, Ft. Meade, MD }\end{array}$ \\
\hline 002 & 061589 & & Soule/Shepard & Memo & $\begin{array}{l}\text { Daily Report, Special Process Laboratory, } \\
\text { National Security Agency, Ft. Mcade, MD }\end{array}$ \\
\hline 003 & 062989 & & Musko & Project Notes & As-Built Drawings \\
\hline 004 & 070389 & & Soule & Memo & $\begin{array}{l}\text { Daily Report, Special Process Laboratory, } \\
\text { National Security Agency, Ft. Mcade, MD }\end{array}$ \\
\hline 005 & 071489 & & Kokalis/Shepard & Memo & $\begin{array}{l}\text { Daily Report, Special Process Laboratory, } \\
\text { National Sccurity Agency, Ft. Mcade, MD }\end{array}$ \\
\hline 006 & 072889 & & Kokalis/Shepard & Memo & $\begin{array}{l}\text { Daily Report, Special Process Laboratory, } \\
\text { National Security Agency, Ft. Meade, MD }\end{array}$ \\
\hline 007 & 080789 & & Kokalis/Shepard & Memo & $\begin{array}{l}\text { Daily Report, Special Process Laboratory, } \\
\text { National Security Agency, Ft. Mcade, MD }\end{array}$ \\
\hline 008 & 081589 & & Kokalis/Shepard & Memo & $\begin{array}{l}\text { Daily Report, Special Process Laboratory, } \\
\text { National Security Agency, Ft. Meade, MD }\end{array}$ \\
\hline 009 & 082489 & & Kokalis/Shepard & Memo & $\begin{array}{l}\text { Daily Report, Special Process Laboratory, } \\
\text { National Security Agency, Ft. Meade, MD }\end{array}$ \\
\hline 010 & 092689 & & Kokalis/Musko & Memo & $\begin{array}{l}\text { Daily Report, Special Process Laboratory, } \\
\text { National Security Agency, Ft. Meade, MD }\end{array}$ \\
\hline 011 & 082989 & & Kokalis/Shepard & Memo & $\begin{array}{l}\text { Daily Report, Special Process Laboratory, } \\
\text { National Security Agency, Ft. Mcade, MD }\end{array}$ \\
\hline 012 & 100489 & & Kokalis/Shepard & Memo & $\begin{array}{l}\text { Daily Report, Special Process Laboratory, } \\
\text { National Security Agency, Ft. Mcade, MD }\end{array}$ \\
\hline 013 & 101289 & 101689 & Kokalis/Shepard & Memo & $\begin{array}{l}\text { Daily Report, Special Process Laboratory, } \\
\text { National Security Agency, Ft. Mcade, MD }\end{array}$ \\
\hline 014 & 101689 & & Kokalis/Shepard & Memo & $\begin{array}{l}\text { Daily Report, Special Process Laboratory, } \\
\text { National Security Agency, Ft. Mcade, MD }\end{array}$ \\
\hline 015 & 110189 & & Kokalis/Shepard & Memo & $\begin{array}{l}\text { Daily Report, Special Process Laboralory, } \\
\text { National Security Agency, Ft. Mcade, MD }\end{array}$ \\
\hline 016 & 110389 & & Kokalis/Shepard & Memo & $\begin{array}{l}\text { Daily Report, Special Process Laboratory, } \\
\text { National Security Agency, Ft. Meade, MD }\end{array}$ \\
\hline 017 & 110789 & & Kokalis/Shepard & Memo & $\begin{array}{l}\text { Daily Report, Special Process Labor tory, } \\
\text { National Security Agency, Ft. Meade, MD }\end{array}$ \\
\hline 018 & 110989 & & Kokalis/Shepard & Miemo & $\begin{array}{l}\text { Daily Report, Special Process Laboratory, } \\
\text { National Security Agency, Ft. Mcade, MD }\end{array}$ \\
\hline
\end{tabular}




\section{DAILY REPORTS 2.7 \\ (Cont'd)}

\begin{tabular}{|c|c|c|c|c|c|}
\hline DR. & Dated & Revd & To/From & Description & Subject \\
\hline 019 & 010390 & & Kokalis/Musko & Memo & $\begin{array}{l}\text { Daily Report, Special Process Laboratory, } \\
\text { National Security Agency, Ft. Meade, MD }\end{array}$ \\
\hline 020 & 013190 & 021290 & Kokalis/Musko & Memo & $\begin{array}{l}\text { Daily Report, Special Process Laboratory, } \\
\text { National Security Agency, Ft. Meade, MD }\end{array}$ \\
\hline 021 & 031490 & 033090 & Kokalis/Shepard & Memo & $\begin{array}{l}\text { Daily Report, Special Process Laboratory, } \\
\text { National Security Agency, Fl. Mcade, MD }\end{array}$ \\
\hline 022 & 032090 & 033090 & Kokalis/Shepard & Memo & $\begin{array}{l}\text { Daily Report, Special Process Laboratory, } \\
\text { National Security Agency, Ft. Mcade, MD }\end{array}$ \\
\hline 023 & 032090 & 033090 & Kokalis/Shepard & Memo & $\begin{array}{l}\text { Daily Report, Special Process Laboratory, } \\
\text { National Security Agency, Ft. Mcade, MD }\end{array}$ \\
\hline 024 & 032890 & 033090 & Kokalis/Shepard & Memo & $\begin{array}{l}\text { Daily Report, Special Process Laboratory, } \\
\text { National Security Agency, Ft. Mcade, MD }\end{array}$ \\
\hline 025 & 033090 & 033090 & Kokalis/Shepard & Memo & $\begin{array}{l}\text { Daily Report, Special Process Laboratory, } \\
\text { National Security Agency, Ft. Mcade, MD }\end{array}$ \\
\hline 026 & 062790 & 071690 & Kokalis/Shepard & Memo & $\begin{array}{l}\text { Daily Report, Special Process Laboratory, } \\
\text { National Security Agency, Ft. Mcade, MD }\end{array}$ \\
\hline
\end{tabular}


$123 / 124$

2.8 Support File for Formal Review of NSA's Operations and Maintenance Concept for the SPL Building 


\section{$125 / 126$}

SUPPORT FILE 2.8

Documents Pertaining to the NSA-Sponsored Formal Peer Review of NSA's sperations and Maintenance Concept for the SPL Building

\begin{tabular}{|c|c|c|c|c|}
\hline OMS- & Dated/Rcvd & To/From & Description & Subject \\
\hline 001 & 0190 & Panelists/Fiarrison & . Report & $\begin{array}{l}\text { Proposed Paneelists' Information Package } \\
\text { for the Peer Review of the SPL } \\
\text { Operations and Maintenance Plan }\end{array}$ \\
\hline 002 & 012390 & File/Harrison & Memo & $\begin{array}{l}\text { Telephone Conference Between David } \\
\text { Kokalis, Wyman Harrison, and Herbert } \\
\text { Stevens, January } 19,1990\end{array}$ \\
\hline \multirow[t]{4}{*}{003} & 012990 & File/Harrison & Memo & $\begin{array}{l}\text { Scoping The Review Of The Operations } \\
\text { and Maintenance Concept For The SPL } \\
\text { Building (Also filed as RNSAOO-OM2) }\end{array}$ \\
\hline & $011<90 / 011490$ & Harrison/Kokalis & Attachment & $\begin{array}{l}\text { Request For Review of NSA's Operations } \\
\text { and Maintenance Concept For The SPL } \\
\text { Building }\end{array}$ \\
\hline & 012390 & File/Harrison & Attachment & $\begin{array}{l}\text { Telephone Conference between David } \\
\text { Kokalis, Wyman Harrison, and Herbert } \\
\text { Stevens - January 19,1990 }\end{array}$ \\
\hline & & & Attachment & $\begin{array}{l}\text { O\&M Objectives ( } 2 \text { pgs) "Scoping The } \\
\text { Review" and "Steps in the Revicw" }\end{array}$ \\
\hline 004 & 013189 & Jones/Harrison & Letter & $\begin{array}{l}\text { "We are very pleased to have you and } \\
\text { your associates..." }\end{array}$ \\
\hline 005 & 020590 & Liarakos/Harrison & Letter & $\begin{array}{l}\text { "Enclosed you will find..." (prelude to } \\
\text { RNSAOO-OM2) }\end{array}$ \\
\hline 006 & 020590 & Morgan/Harrison & Letter & $\begin{array}{l}\text { "Enclosed you will find..." (prelude to } \\
\text { RNSAOO-OM2) }\end{array}$ \\
\hline 007 & 020590 & Jones/Harrison & Letter & $\begin{array}{l}\text { "Enclosed you will find..." (prelude to } \\
\text { RNSAOO-OM2) }\end{array}$ \\
\hline 008 & $020690 / 021290$ & Kokalis/Shepard & Memo & $\begin{array}{l}\text { Review of the Operations and } \\
\text { Maintenance Concepts for the Special } \\
\text { Process Laboratory (SPL) at Ft. Meade, } \\
\text { MD (List of participants) }\end{array}$ \\
\hline 009 & 021990 & Jones/Harrison & Letter & $\begin{array}{l}\text { General discussion of various subjects } \\
\text { relevant to O\&M review report. (Informal } \\
\text { letter with attachments) }\end{array}$ \\
\hline 010 & & File/Stevens & Drawings & $\begin{array}{l}\text { SPL Building Construction Specilication } \\
\text { Drawings }\end{array}$ \\
\hline 011 & 033090 & Stouder/Harrison & Letter & $\begin{array}{l}\text { Expression of appreciation for efforts of } \\
\text { Motorola panelists }\end{array}$ \\
\hline 012 & 040590 & File/Miller & Memo/Diskette & $\begin{array}{l}\text { Closing of O\&M Quality Assurance } \\
\text { Files (RNSA-OM) }\end{array}$ \\
\hline
\end{tabular}


2.9 Basic SPL Specifications and Preliminary Design Calculations 


\section{BASIC SPL SPECIFICATIONS AND PRELIMINARY DESIGN CALCULATIONS 2.9}

SD. Date Description

$00 \mathrm{i} \quad 061485$

$002 \quad 061485$

$003 \quad 061485$

$004 \quad 061485$

005

051587

006

0387

007

0387

008

0387

009

0387

010

0387

011

051088

012

011188

$013 \quad 011188$

014

031888

015

016
U. S. Army Corps of Engineers, Baltimore District, Construction Specifications, Special Process Laboratories, Fort George G. Mieade, Maryland, Volume I (Divisions 1 - 8) [A/E Firm: HDR/Wagner Group]

U. S. Army Corps of Engineers, Baltimore District, Construction Specifications, Special Process Laboratories, Fort George G. Meade, Maryland, Volume II (Divisions 9 - 14) [A/E Firm: HDR/Wagner Group]

U. S. Army Corps of Engineers, Baltimore District, Construction Specifiuations, Special Process Laboratories, Fort George G. Meade, Maryland, Volume III (Divisions 15) [AE Firm: HDR/Wagner Group]

U. S. Army Corps of Engineers, Baltimore District, Construction Specifications, Special Process Laboratories, Fort George G. Meade, Maryland, Volume IV \& V (Divisions 16, and Misc. Schedules) [AE Firm: HDR/Wagner Group]

Fit-up for Special Process Laboratories, Fort George G. Meade, Maryland, Budget Estimatc Update for Equipment Fit-up [A/E Firm: HDR/Wagner Group]

Fit-up for Special Process Laboratorics, Fort George G. Meade, Maryland, Contract Documents [A/E Firm: HDR/Wagner Group]

Fit-up for Special Process Laboratories, Fort George G. Meade, Maryland, Contract Documents Volume II [A/E Firm: HDR/Wagner Group]

Fit-up for Special Process Laboratories, Fort George G. Meade, Maryland, Contract Documents Volume III [A/E Firm: HDR/Wagner Group]

Fit-up for Special Process Laboratories, Fort George G. Meade, Maryland, Contract Documents Volume IV [A/E Firm: HDR/Wagner Group]

Fit-up for Special Process Laboratories, Fort George G. Meade, Maryland, Contract Documents Volume V [A/E Firm: HDR/Wagner Group]

(Edition) Special Process Laboratories Weekly Activity Report for Phase Two Use (Produced by Lawrence Livermore National Laboratory or Personnel on a Weekly Basis)

Special Process Laboratory (SPL) Acquisition Purchase Description R1.(0)1

Special Process Laboratory (SPL) Transfer Statement of Work (NSA)

National Semiconductor Proposal, Volume 1 (Technical) [Produced by National Semiconductor Corporation]

National Security Agency, Special Process Laboratory, Fort Meade, Maryland, Volume V, Base Cost

Special Process Laboratory (SPL) 1.2 Micron Acquisition Design Statement of Work - Final (NSA) 


\section{BASIC SPL SPECIFICATIONS AND PRELIMINARY DESIGN CALCULATIONS 2.9 (Cont'd)}
SD.
Date
Description

\begin{tabular}{|c|c|}
\hline 017 & 080488 \\
\hline 018 & 0888 \\
\hline 019 & 0888 \\
\hline 020 & 090988 \\
\hline 021 & 101288 \\
\hline 022 & 102688 \\
\hline 023 & 103188 \\
\hline 024 & 103188 \\
\hline 025 & 103188 \\
\hline 026 & 103188 \\
\hline 027 & 120688 \\
\hline 028 & 111488 \\
\hline
\end{tabular}

Special Process Laboratory (SPL) Acquisition Purchase Description (NSA)
Department of Defense, Special Process Laboratories, Fit-up for Building Areas A, C, D, Fort George G. Meade, Maryland, Volume I [A/E Firm: HDR/Wagner Group]
Department of Defense, Special Process Laboratories, Fit-up for Building Aras A, C, D, Fort George G. Meade, Maryland, Volume II [A/E Firm: HDR/Wagner Group]

Maryland Procurement Office Notice of Award (National Semiconductor Corporation) (Acceptance of NS Proposal Dated 1 September 1988) [NSA]

75\% Design Calculations For Facility Enhancements to Special Process Laboratorics (First Submission by National Semicunductor) [A/E Firm: Wagner Group]

95\% Design Calculations For Facility Enhancement to Special Process Laboratories (Sccond Submission by National Semiconductor) [A/E Firm: Wagner Group]

95\% Interface Control Document, National Semiconductor, Special Process Laboratory, Fort G. Meade, Maryland, Facility Enhancement, Draft - Final Step 1 [A/E Firm: Wagner Group]

95\% Pre-Pl chase Specifications, National Semiconductor, Special Process Laboratory, Fort G. Meade, Maryland, Facility Enhancements [A/E Firm: Wagner Group]

95\% Construction Specifications, National Semiconductor, Special Process Laboratory, Fort G. Meade, Maryland, Facility Enhancements, Package 1 - Removal Octobor 1988 Volume I [A/E Firm: Wagner Group]

95\% Construction Specifications, National Semiconductor, Special Process Laboratory, Fort G. Meade, Maryland, Facility Enhancements, Package 2 - Removal October 1988 Volume II [A/E Firm: Wagner Group]

LEPCO Incorporated, Finalized Proposal for National Semiconductor, Fort Mcade MEBES Faxcility (LEPCO, Inc.)

111488

$029 \quad 1288$

Interface Control Document, National Semiconductor, Special Process Laboratory, Fort G. Meade, Maryland, Facility Enhancement, Draft - Final Step 1 - Revised (Originally Submitted 10-31-88) [A/E Firm: Wagner Group]

$030 \quad 1288$

Construction Specifications, National Semiconductor, Special Process Laboratory, Fort G. Meade, Maryland, Facility Enhancements, Package 2 - Enhancements, Volume II (Submission) [A/E Firm: Wagner Group]

Construction Specifications, National Semiconductor, Special Process Laboratory, Fort G. Meade, Maryland, Deionized Water Enhancements, Package 3 - Enhancements, Volume III (Submission) [A/E Firm: Wagner Group]

$031 \quad 1288$

Construction Specifications, National Semiconductor, Special Process Laboratory, Fort G. Meade, Maryland, Package 4 - Cryogenic Systems, , Volume IV (Submission) |A/E Firm: Wagner Group] 


\section{BASIC SPL SPECIFICATIONS AND PRELIMINARY DESIGN CALCULATIONS 2.9} (Cont'd)

SDDate

032

033

034

035

036

037

038
091389

050390

022690

051989

080889

091389

031590
Description

Construction Specifications, National Semiconductor, Special Process Laboratory, Fort G. Meade, Maryland, Package 5 - Enivironmental Protection Systems, , Volume V (Submission) [A/E Firm: Wagner Group]

National Semiconductor, Special Process Laboratory, Process Equipment Installation Specification - Issued For Construction (These specifications were used by Noone Electric Company for Installation Purposes) [A/E Firm: Wagner Group]

National Semiconductor, Special Process Laboratory, Process Equipment Installation Specification - Issued for Construction (These Specifications Were Used By Pil nuck Mechanical

National Semiconductor, Special Process Laboratory, Process Equipment Installation Specification - Issued for Construction (These Specifications Were Used By Pilchuck Mechanical

National Semiconductor Equipment - Test Plan, Facility Installation, Special Process Laboratory

NSC/Wagner Response to Issues Raised by Argonne National Laboratory (Volume 1)

NSC/Wagner Response to Issues Raised by Argonne National Laboratory (Volume 2) 
$132 / 34$

\subsection{Argonne Proposals and NSA Contract Letters}


ARGONNE PROPOSALS AND NSA CONTRACT LETTERS 2.10

\begin{tabular}{|c|c|c|c|c|c|}
\hline $\mathrm{CD}$ - & Proposal No. & Date & To/From & Description & Subject \\
\hline 001 & P- 88120 & 063088 & $\begin{array}{l}\text { USACE/BD / } \\
\text { Harrison }\end{array}$ & Proposal & $\begin{array}{l}\text { Performance Assessment of Piping System } \\
\text { to Support Semiconductor Manufacturing for } \\
\text { the National Security Agency }\end{array}$ \\
\hline 002 & P-88120 & 082488 & $\begin{array}{l}\text { Dept. of Army } \\
\text { F\&A Office / } \\
\text { Daiton }\end{array}$ & Letter & $\begin{array}{l}\text { "This letter confirms the U. S. Department } \\
\text { of Energy's (DOE's) acceptance of the subject } \\
\text { MIPR [E8588ZN75] for work to be } \\
\text { performed by the Argonne National } \\
\text { Laboratory (ANL)..." }\end{array}$ \\
\hline 003 & $\begin{array}{l}\text { P-88120,(Rev. } \\
\text { 1) }\end{array}$ & 092088 & $\begin{array}{l}\text { USACE/BD / } \\
\text { Harrison }\end{array}$ & Proposal & $\begin{array}{l}\text { Performance Assessment of Systems to } \\
\text { Support Semiconductor Manufacturing for } \\
\text { the National Security Agency }\end{array}$ \\
\hline 004 & $\begin{array}{l}\text { P-88120, } \\
\text { (Rev. 1) }\end{array}$ & 093088 & $\begin{array}{l}\text { Comrnander, } \\
\text { F\&A / Dalton }\end{array}$ & Letter & $\begin{array}{l}\text { "This letter confirms the U. S. Dep.rtment } \\
\text { of Energy's (DOE) acceptance of the subject } \\
\text { MIPR [E8588ZN75, Amendment 1)] for } \\
\text { work to be performed by the Argonne } \\
\text { National Laboratory (ANL)...." }\end{array}$ \\
\hline 005 & P-89033 & 010489 & $\begin{array}{l}\text { USDoD, NSA / } \\
\text { Harrison }\end{array}$ & Proposal & $\begin{array}{l}\text { Performance Assessment of Systems to } \\
\text { Support Semiconductor Manufacturing for } \\
\text { the National Security Agency }\end{array}$ \\
\hline 006 & P-89033 & 032289 & Rogan/Dalton & & $\begin{array}{l}\text { "This letter confirms the U. S. Department } \\
\text { of Energy's (DOE) acceptance of the subject } \\
\text { agreement [\#N-2079-89) for work to be } \\
\text { performed by the Argonne National } \\
\text { Laboratory (ANL)..." }\end{array}$ \\
\hline 007 & $\begin{array}{l}\text { P-89033, } \\
\text { (Rev. 1) }\end{array}$ & 061989 & $\begin{array}{l}\text { USDoD, NSA / } \\
\text { Harrison }\end{array}$ & Proposal & $\begin{array}{l}\text { Performance Assessment of Systems to } \\
\text { Support Semiconductor Manufacturing for } \\
\text { the National Security Agency }\end{array}$ \\
\hline 008 & $\begin{array}{l}\text { P:89033, } \\
\text { (Rev. 1) }\end{array}$ & 101289 & Walsh/Rogan & Letter & $\begin{array}{l}\text { "Reference is made to NSA/CSS letter, } \\
\text { Serial: N-2079.89, dated } 3 \text { March } 1989 \\
\text { which established MOD } 7052.89 \text {...for } \\
\text { FY } 1989 \text { consultation support in the } \\
\text { assessment of major facility systems at Fort } \\
\text { Meade, Marylard, by the Argonne National } \\
\text { Laboratory. Please consider this letter as a } \\
\text { formal purchase request...to continue the } \\
\text { effort..." }\end{array}$ \\
\hline 009 & P-89033 & 091190 & Combs/Harrison & Memo & $\begin{array}{l}\text { Revised Closeout Schedule and Budget for } \\
\text { Work Conducted Under Proposal P-89033, } \\
\text { "Performance Assessment of Systems to } \\
\text { Support Semiconductor Manufacturing for } \\
\text { the National Security Agency" }\end{array}$ \\
\hline
\end{tabular}


ARGONNE PROPOSALS AND VSA CONTRACT LETTERS 2.10

\begin{tabular}{|c|c|c|c|c|c|}
\hline $\mathrm{CD}$ - & Proposal No. & Date & To/From & Description & Subject \\
\hline 010 & P.89033 & 090790 & Walsh/Rogan & Letter & $\begin{array}{l}\text { "Reference is made to NSA/CSS letter, } \\
\text { Serial: N-2079-89, dated } 12 \text { October } 1989 \\
\text { which established MOD } 7000.90 \text {...for } \\
\text { FY } 1989 \text { consultation support in the } \\
\text { assessment of major facility systems at Fort } \\
\text { Meade, Maryland, by the Argonne National } \\
\text { Laboratory. Please consider this letter as an } \\
\text { amendment to the referenced purchase } \\
\text { request..." }\end{array}$ \\
\hline
\end{tabular}



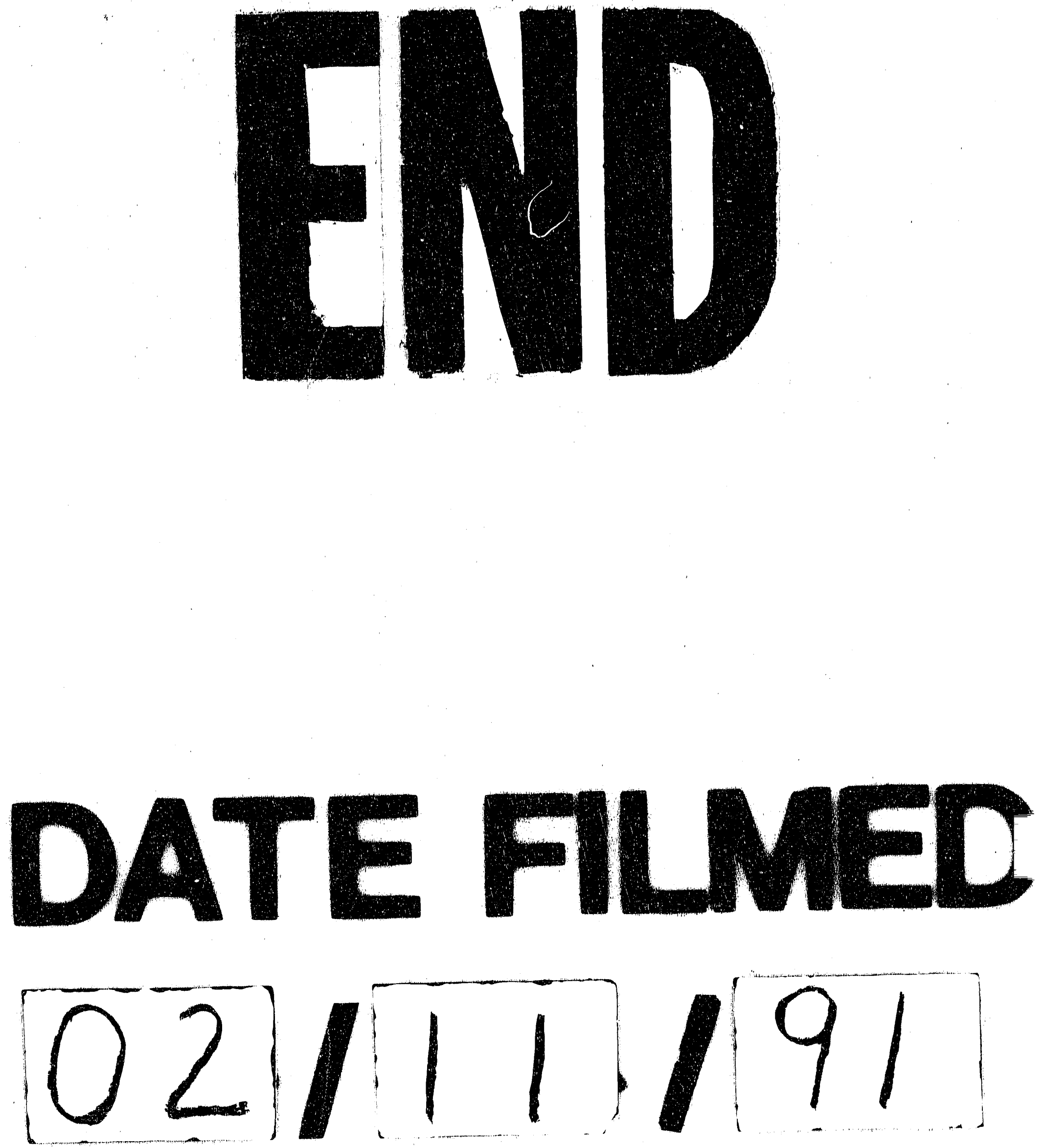
